\title{
RELIABILITY ANALYSIS OF LOW-SILVER BGA SOLDER JOINTS USING FOUR FAILURE CRITERIA
}

\author{
A Thesis \\ presented to \\ the Faculty of California Polytechnic State University, \\ San Luis Obispo
}

\author{
In Partial Fulfillment \\ of the Requirements for the Degree \\ Master of Science in Industrial Engineering
}

by

Erin A. Kimura

August 2012 
(C) 2012

Erin A. Kimura

ALL RIGHTS RESERVED 


\section{COMMITTEE MEMBERSHIP}

TITLE:

Reliability analysis of low-Ag BGA solder joints using four

failure criteria

AUTHOR: $\quad$ Erin A. Kimura

DATE SUBMITTED: $\quad$ August 2012

COMMITTEE CHAIR: Dr. Jianbiao Pan, Professor of Industrial and Manufacturing

Engineering

COMMITTEE MEMBER: Dr. Tao Yang, Professor of Industrial and Manufacturing

Engineering

COMMITTEE MEMBER: Dr. Daniel Waldorf, Professor of Industrial and Manufacturing Engineering 


\begin{abstract}
Reliability analysis of low-Ag BGA solder joints using four failure criteria Erin A. Kimura
\end{abstract}

The appropriate selection of failure criterion for solder joint studies is necessary to correctly estimate reliability life. The objective of this study is to compare the effect of different failure criteria on the reliability life estimation. The four failure criteria in this study are a 20\% resistance increase defined in the IPC-9701A standard, a resistance beyond $500 \Omega$, an infinite resistance (hard open), and a failure criterion based on $\bar{X}$ and R control charts. Accelerated thermal cycling conditions of a low-silver BGA study included $0{ }^{\circ} \mathrm{C}$ to $100{ }^{\circ} \mathrm{C}$ with ten minute dwell times and $-40^{\circ} \mathrm{C}$ to $125^{\circ} \mathrm{C}$ with ten minute dwell times. The results show that the life estimation based on $\bar{X}$ and $\mathrm{R}$ failure criterion is very similar to the life estimation when a $20 \%$ resistance increase defined in the IPC9701A failure criterion is used. The results also show that the reliability life would be overestimated if the failure criterion of a resistance threshold of $500 \Omega$ or an infinite resistance (hard open) is used.

Keywords: Solder joint, failure criteria, $\bar{X}$ and R charts, statistical process control 


\section{ACKNOWLEDGMENTS}

I would like to thank Greg Henshall, Michael Fehrenbach, Chrys Shea, Ranjit

Pandher, Ken Hubbard, Girish Wable, Gnyaneshwar Ramakrishna, Quyen Qu, and Ahmer Syed for sharing the low-silver BGA data. I would like to thank Surface Mount Technology Association (SMTA) Silicon Valley chapter for providing scholarship for this study.

I would also like to thank my thesis advisor, Dr. Jianbiao Pan, for sharing with me his enthusiasm for research and for his constant guidance and support throughout this project. 


\section{Table of Contents}

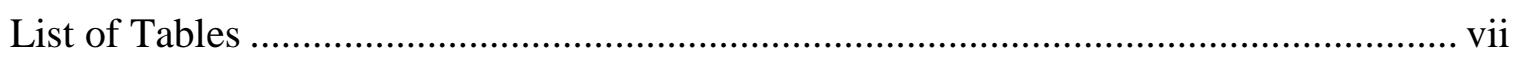

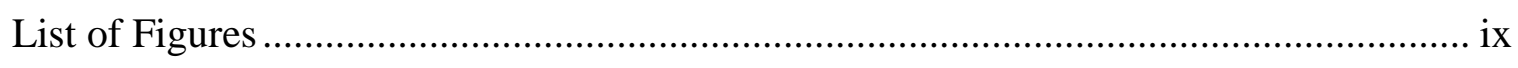

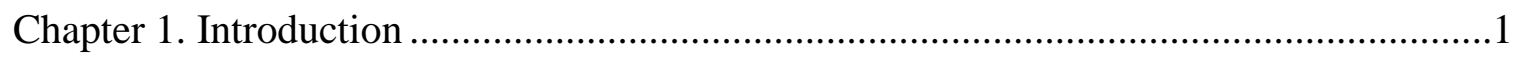

Chapter 2. Literature Review ...............................................................................

2.1 Low-silver Ball Grid Array (BGA) Assemblies .............................................

2.2 Design for Reliability ........................................................................

2.3 Accelerated Life Testing ....................................................................

2.3.1 Accelerated Thermal Cycling (ATC)...........................................

2.3.2 Drop Shock Reliability ............................................................

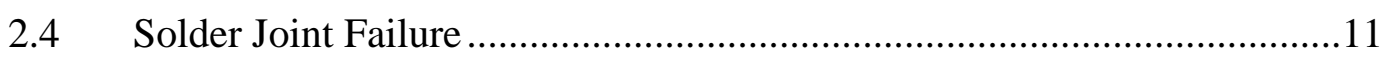

2.4.1 Solder Joint Failure Criteria ..........................................................11

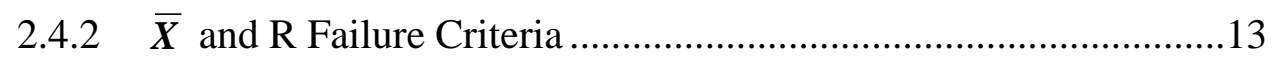

Chapter 3. Low-Silver BGA Assembly Study ………………….................................16

3.1 Low-Silver BGA Experimental Setup: Accelerated Thermal Cycling .........16

Chapter 4. Analysis and Results: Comparison of Four Failure Criteria ............................19

4.1 Comparison of Four Failure Criteria...........................................................20

4.1.1 Selection of Failure Criteria ........................................................20

4.1.2 $\quad \bar{X}$ and R chart Failure Criterion ..............................................21

4.1.3 IPC-9701A, 500 Ohm, and Infinite Resistance Failure Criteria ...22 
4.2 Results: Comparison of Failure Criteria

Chapter 5. Analysis and Results: Reliability analysis of low-Ag BGA ATC data

5.1 Reliability Life Distribution Fitting ................................................27

5.1.1 Weibull Parameter Estimation .............................................28

5.2 ANOVA using $\bar{X}$ and R Failure Criterion ..........................................29

5.2.1 Experimental Design.........................................................30

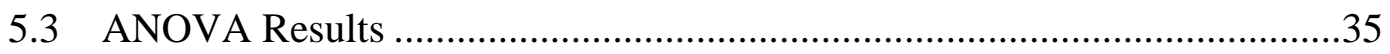

5.3.1 ANOVA Results: Weibull Characteristic Life: $0{ }^{\circ} \mathrm{C}$ to $100{ }^{\circ} \mathrm{C}$

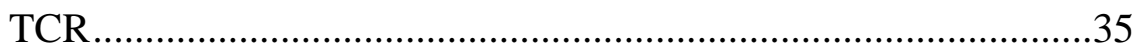

5.3.2 ANOVA Results: Weibull Characteristic Life: $-40^{\circ} \mathrm{C}$ to 125

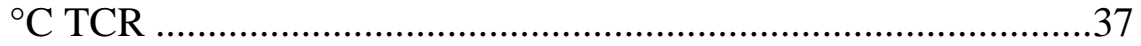

5.3.3 ANOVA Results: Weibull Slope: $0{ }^{\circ} \mathrm{C}$ to $100^{\circ} \mathrm{C}$ TCR ...................38

5.3.4 ANOVA Results: Weibull Slope $-40^{\circ} \mathrm{C}$ to $125^{\circ} \mathrm{C}$ TCR ...............39

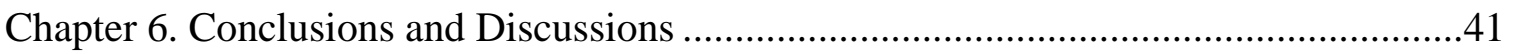

6.1 Package Construction and Weibull Characteristic Life Relationship ..........42

6.2 Effect of Temperature Cycling Range on Weibull Characteristic Life .......42

6.3 Possible Further Work ...................................................................43

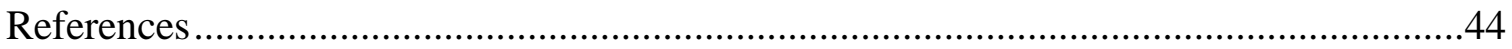

Appendix A: Cycles to failure for low-silver BGA data for each failure criteria..............50

Appendix B: AIC Values for Weibull and Lognormal Distributions ............................71 


\section{List of Tables}

Table 1. Solder joint failure criteria standards [7] ………...................................... 12

Table 2. Failure criteria used by major electronics companies [6] ................................ 12

Table 3. Accelerated thermal cycling (ATC) experimental matrix for the low-silver

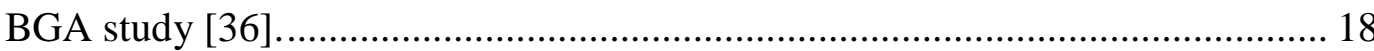

Table 4. Number of components meeting each failure criterion with \% out of 720 total

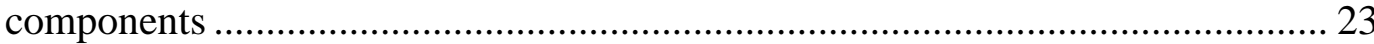

Table 5. $\overline{\boldsymbol{X}}$ and R failure criterion compared to IPC-9701A …………………….......... 25

Table 6. Average cycles to failure (\% Total Cycles*) for four failure criteria ................. 25

Table 7. Weibull characteristic life values for each treatment........................................ 26

Table 8. Weibull slope values for each treatment........................................................ 26

Table 9. Average AIC values for Weibull and Lognormal distributions for each

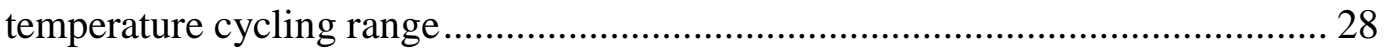

Table 10. Weibull parameter estimation for one cell...................................................... 28

Table 11. Ball alloy and paste alloy consolidation ........................................................... 31

Table 12. Number of components for estimation of Weibull characteristic life and

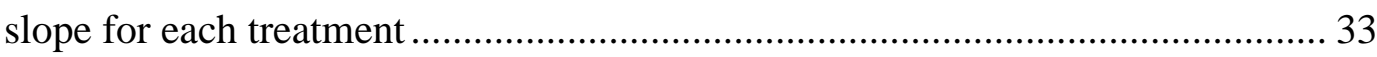

Table 13. ANOVA Table for Weibull characteristic life $\left(0\right.$ to $\left.100{ }^{\circ} \mathrm{C}\right)$.............................. 35

Table 14. Tukey's multiple comparisons for Weibull characteristic life of different

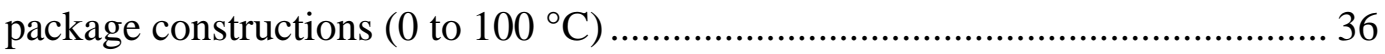


Table 15. Tukey's Test for Weibull characteristic life $\alpha$ for different ball/paste ( 0 to $\left.100{ }^{\circ} \mathrm{C}\right)$

Table 16. ANOVA Table for Weibull characteristic life $\alpha\left(-40\right.$ to $\left.125^{\circ} \mathrm{C}\right)$..................... 38

Table 17. Tukey's Test for Weibull characteristic life for different package

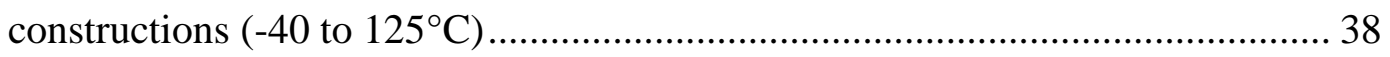

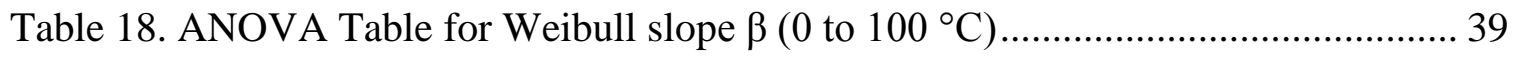

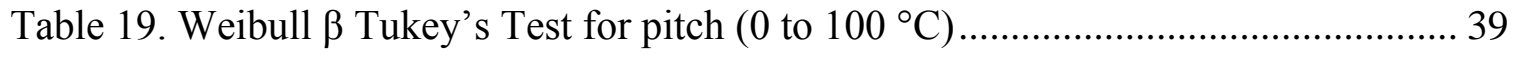

Table 20. ANOVA Table for Weibull characteristic life $\beta\left(-40\right.$ to $\left.125^{\circ} \mathrm{C}\right)$.................... 40 


\section{List of Figures}

Figure 1. Cost of design change during the product development cycle [1] ................... 5

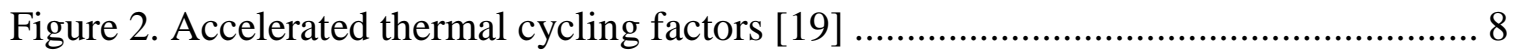

Figure 3. BGA solder joint crack resulting in electrical discontinuity and solder joint

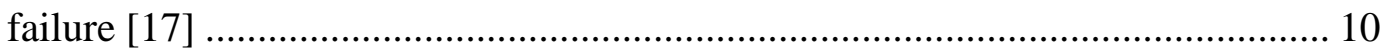

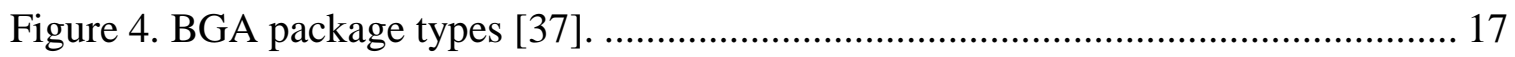

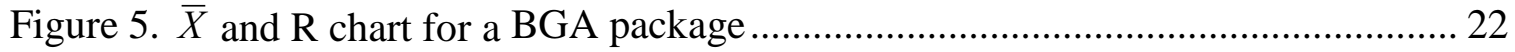

Figure 6. Cycles to failure of four failure criteria for one package .............................. 24

Figure 7. Weibull plot for one cell using four failure criteria.................................... 29

Figure 8. Weibull characteristic life LS Means for pitch $\left(0\right.$ to $\left.100{ }^{\circ} \mathrm{C}\right)$........................... 36

Figure 9. Weibull characteristic life LS Means for ball/paste $\left(0\right.$ to $\left.100{ }^{\circ} \mathrm{C}\right)$.................... 37

Figure 10. Weibull characteristic life LS Means for pitch $\left(-40\right.$ to $\left.125^{\circ} \mathrm{C}\right)$..................... 38

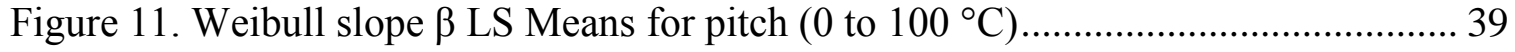




\section{Chapter 1. Introduction}

As the technologies of the microelectronics industry continue to advance, new solder alloy materials, manufacturing processes, and designs add to the complexity of microelectronics packaging. Although the implications of these new technologies on product reliability may not be fully understood, consumers expect these products to exhibit high performance and durability. In addition, microelectronics manufacturers may experience high costs of unreliability due to product warranties [1]. For many other industries, such as automotive, airline, and military, safety is contingent on product reliability as well.

Because the reliability of a product is heavily influenced by the design process, many products are engineered for high reliability during design. The design for reliability methodology is utilized to produce the highest level of product reliability, while minimizing the design process time. From an engineering perspective, reliability can be defined as:

The probability that an item will perform a required function without failure under stated conditions for a stated period of time [1].

In the microelectronics industry, reliability is largely dependent on the integrity of solder, which is used in different levels of the electronic assembly sequence. Solder 
provides the electrical, thermal, and mechanical continuity in electronics assemblies. Solder alloys used in electronics manufacturing range from the once widely used $\mathrm{SnPb}$ solders to lead-free solders with additional micro-additives. For the lead-free SAC $(\mathrm{SnAgCu})$ sphere alloys used in Ball Grid Array (BGA) assemblies, low-silver sphere alloys have become increasingly popular due to their improved drop shock performance over the more traditional SAC305 (3\% Ag) and SAC405(4\% Ag) spheres [2]-[5].

Microelectronics reliability studies are necessary for the understanding of thermal fatigue performance of solder joints, product qualification, and life estimation. However, the appropriate selection of failure criterion for solder joint studies is necessary to correctly estimate reliability life. Failure criteria can be categorized as an increase in resistance relative to the initial value, resistance threshold, or electrical discontinuities [6],[7]. Consequently, the use of many different solder joint failure criteria in industry results in reliability analyses which are difficult to compare.

The low-silver BGA study, an industry consortium study by G. Henshall et al., was undertaken to characterize the influence of solder alloy type and reflow parameters on the reliability life of the BGA assemblies [7]. The experiment included accelerated thermal cycling for reliability analysis of BGA assemblies. The IPC-9701A failure criterion was selected to identify cycles to failure for the accelerated thermal cycling data. The failure data was fit to the Weibull distribution to estimate the characteristic life $(\alpha)$ and slope $(\beta)$ for each treatment.

In this study, the accelerated thermal cycling data from the low-silver BGA study was re-analyzed using four failure criteria. Because the results of the reliability life analysis depend on the failure criteria used, this study addresses the effect of failure 
criteria selection on the reliability life low-silver BGA assemblies. The following four failure criteria were selected for the analysis: a $20 \%$ resistance increase defined in the IPC-9701A standard, a resistance beyond $500 \Omega$, an infinite resistance measurement (hard open), and a failure criterion based on $\bar{X}$ and $\mathrm{R}$ control chart developed by Pan and Silk [7]. The $\bar{X}$ and $\mathrm{R}$ failure criterion is based on the $\bar{X}$ and $\mathrm{R}$ charts of statistical process control, and is described in detail in the literature review section. 


\section{Chapter 2. Literature Review}

By providing the electrical, thermal, and mechanical continuity in electronics assemblies, solder plays a vital role in the microelectronics industry. The functionality of these assemblies is dependent on the integrity of the solder, which is used throughout the electronic assembly process [9]Error! Reference source not found.. A variety of advanced package types are used to meet consumer demands for the high performance and miniaturization of electronics. These include Ball Grid Array (BGA), Flip Chip Package, Chip Scale Package (CSP), Plastic Quad Flat Pack (PQFP), and Direct Chip Attach (DCA) [9]. The solder alloys used in electronics manufacturing range from the once widely used $\mathrm{SnPb}$ solders to lead-free solders with additional micro-additives.

\subsection{Low-silver Ball Grid Array (BGA) Assemblies}

Due to the toxicity of lead and environmental regulations which aim to eliminate its use in electronics, a variety of new solder joint alloys have been introduced to replace the once common $\mathrm{SnPb}$ alloys [9].

Low-silver SAC sphere alloys (1\% or $2 \% \mathrm{Ag}$ ) have become an increasingly popular type of lead-free solder used in Ball Grid Array (BGA) electronic packages due to the improved drop shock performance over SAC305 (3\% Ag) and SAC405 (4\% Ag) [2]-[5]. The addition of micro-additives to low-silver BGA alloys can also have a significant effect on improving the drop shock performance of the packages as well [3]. 
The investigation of drop shock performance of electronics has become very important due to the popularity of handheld electronic devices [5].

\subsection{Design for Reliability}

The reliability of a product is heavily influenced by the design process. Because correcting design faults becomes more costly as the product development cycle progresses (See Figure 1), it is important to detect design faults as early as possible through reliability engineering [1] The goal of design for reliability is to produce the highest level of product reliability, while minimizing the design process time.

The broad field of reliability engineering includes materials testing and modeling, finite element modeling and simulation, failure mode and effects analysis, reliability tests (such as accelerated life testing), and reliability life analysis [1,9]. The reliability life of a product can be determined from the statistical analysis of accelerated life testing data.

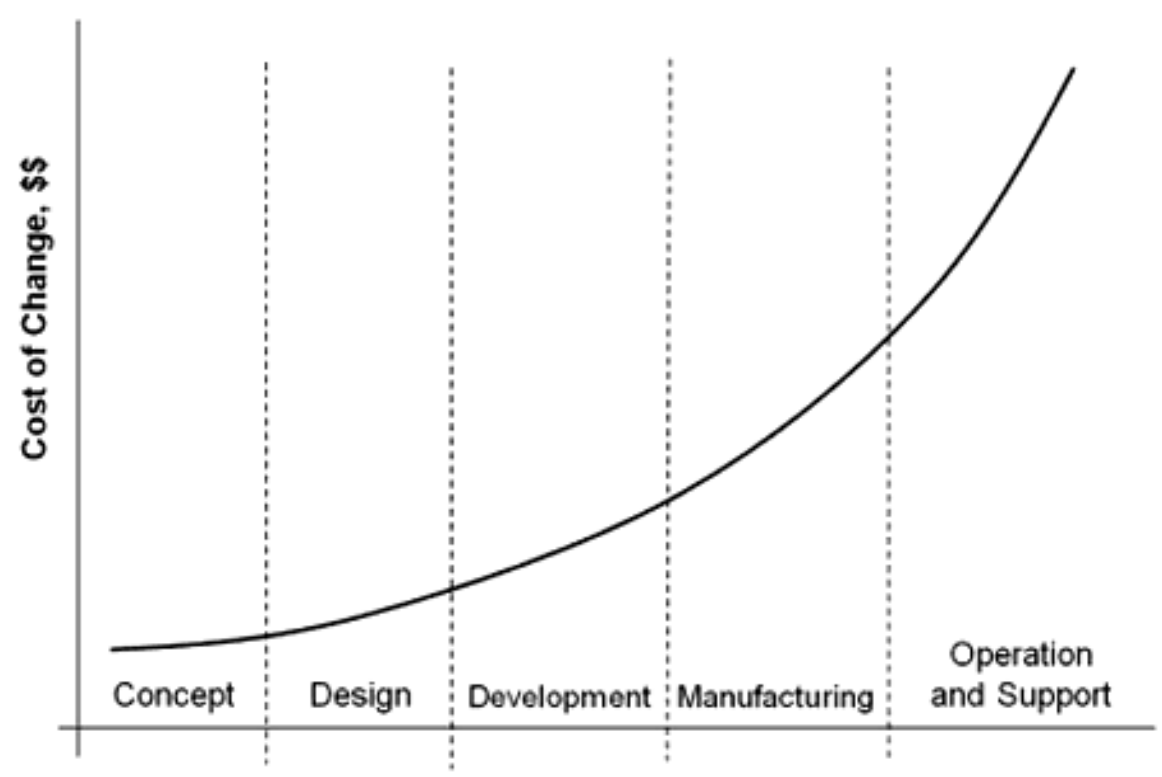

Figure 1. Cost of design change during the product development cycle [1]. 
Reliability engineering is oftentimes necessary for product qualification in the electronics industry.

\subsection{Accelerated Life Testing}

Accelerated tests utilize high stress levels to precipitate component failures in a relatively short time frame. In industry, they are performed to qualify a product for use and to evaluate product reliability. Accelerated tests are necessary when evaluating a component or product for failure under regular use that would not yield a sufficient amount of failures within a reasonable amount of time $[11,12]$. Due to the oftentimes short design process for microelectronics, this is almost always the case. Failures due to accelerated life testing are the result of the same failure mechanisms as failures with typical use, but in a much shorter (accelerated) time frame [13]. Accelerated test conditions must consider typical use conditions, anticipated failure modes, and available test approaches and techniques. The most common accelerated life tests include:

- high temperature (steady-state) dwell,

- low temperature storage,

- thermal cycling,

- power cycling,

- thermal shock,

- thermal gradients,

- fatigue tests,
- mechanical shock,

- drop shock,

- sinusoidal vibration,

- random vibration,

- creep/stress-relaxation,

- voltage extremes,

- high humidity, and

- radiation [12]. 
The reliability analyses from accelerated life testing data allow researchers to pinpoint weaknesses and to make improvements in the design of electronics, material selection, and the electronics manufacturing process [12].

The objective of accelerated life testing is to identify the failure modes and mechanisms, and to collect statistical information from the failure data collected [12]. The failure data collected from accelerated tests includes data (commonly cycles-tofailure or time-to-failure) from failed and not failed units. Units that survive the entire duration of the test are right-censored for the analysis. After the data is fit to a lifetime distribution, distribution parameters are estimated. Common lifetime distributions include the Weibull, Exponential, and Lognormal distributions.

\subsubsection{Accelerated Thermal Cycling (ATC)}

Microelectronics and their solder joints are subject to thermal stresses during typical use. Accelerated thermal cycling (ATC) is the type of accelerated test which mimics these thermal stresses. Accelerated thermal cycling is used to evaluate the thermal fatigue performance of electronic packages. The test is accelerated through increasing the rate of heating or cooling, increasing the difference between the peak (maximum and minimum) temperatures, and decreasing the dwell time at peak temperatures [13]. The data analyzed in this study is accelerated thermal cycling (ATC) data from the low-silver BGA data. The experimental setup and thermal cycling conditions for accelerated thermal cycling data from the low-silver BGA study are described in detail in the following section. 


\subsubsection{Accelerated Thermal Cycling Conditions}

Because thermal cycling conditions mimic the thermal stresses from typical use, selection of thermal cycling conditions is important to the accuracy of component reliability evaluation. This could be from internal factors (such as power dissipation), or external factors (such as daily and seasonal temperature changes). Research has demonstrated that acceleration factors (ramp rate, dwell time, and temperature cycling range) affect fatigue life differently. The selection of these parameters should depend on the specific application of the device, and the conditions in which it will be used. These factors are shown below in Figure 2. During accelerated thermal cycling, failure begins with crack initiation followed by crack propagation. A larger temperature cycling range and increased dwell times will results in more creep strain, which reduces cycles-to-failure

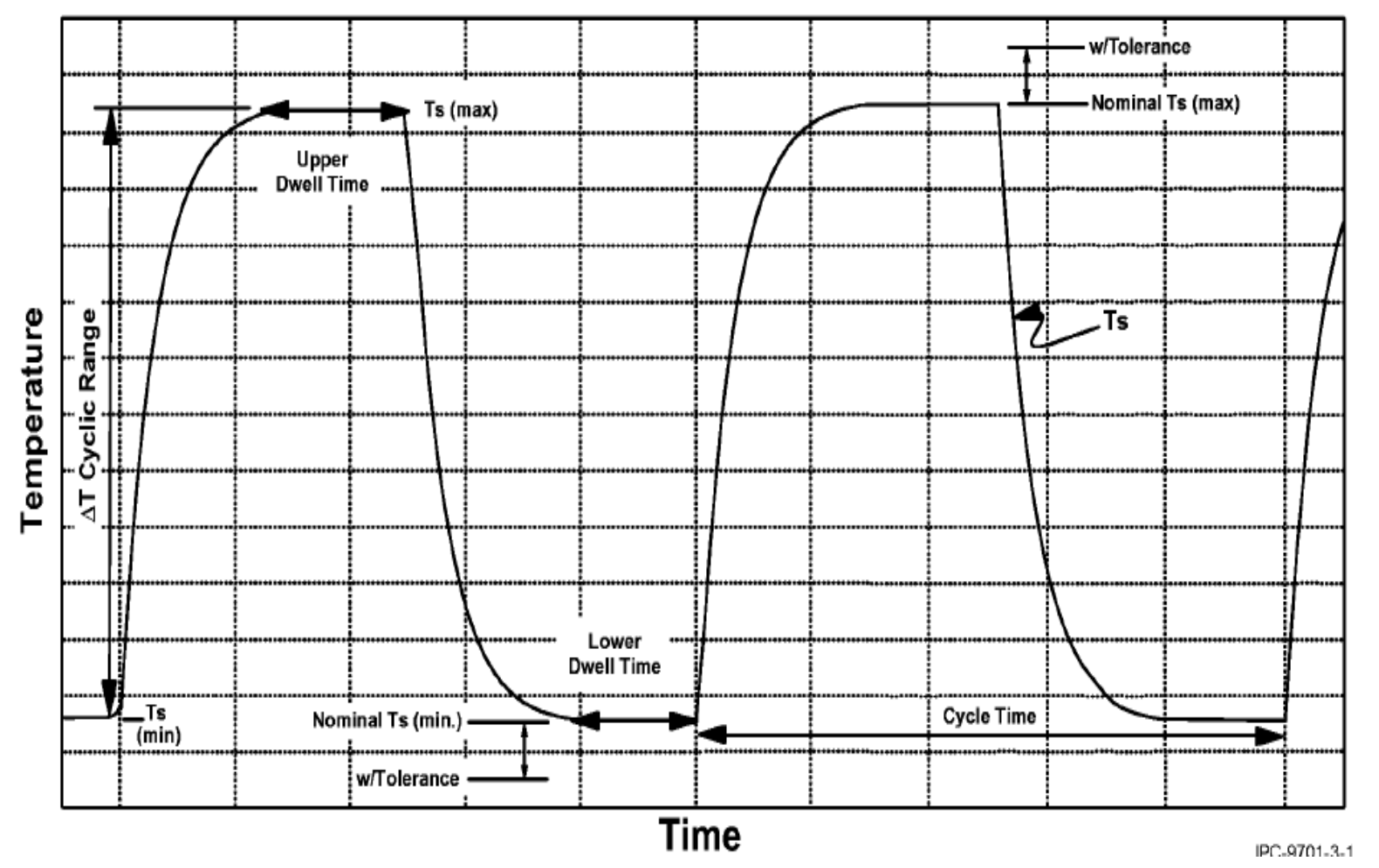

Figure 2. Accelerated thermal cycling factors [24]. 
[13],[15]. The effect of ramp rate is not as clear. Although increasing the ramp rate will decrease the overall test time, some research has shown that increasing the ramp rate will not affect the cycles to failure [16]. Other research has shown that decreasing the ramp rate results in more creep strain, decreasing the cycles-to-failure $[17,18]$.

For BGA assemblies, the $\mathrm{SAC}$ spheres showed a longer fatigue life than $\mathrm{SnPb}$ solder joints for $0-100{ }^{\circ} \mathrm{C}$ and -40 to $125{ }^{\circ} \mathrm{C}$ temperature cycling ranges [13]. Additional literature describes how $\mathrm{Pb}$-free solder, such as SAC alloys, results in a longer fatigue life with greater cycles-to-failure [19]-[23].

Package size shows to have an influence on thermal fatigue as well. A study showed that increasing pitch size for BGA packages size results in lower cycles to failure for accelerated thermal cycling [24]. Other research has shown that the size of the component (including ball pitch and pad size) has a statistically significant effect on fatigue reliability of BGA packages as well $[25,26]$.

\subsubsection{Drop Shock Reliability}

Due to the popularity of consumer handheld electronics, drop shock reliability has been an important area of study in microelectronics reliability. Although initially SAC305 and SAC405 (3\% and 4\% silver, respectively) were the most popular alternatives $\mathrm{Pb}$ solder alloys, there are drop shock reliability concerns with these alloys. Due to the higher strength and lower acoustic impedance, SAC305 and SAC405 transfer stress to the component more readily [3]. Low silver alloys (SAC105 and 205) have shown to have better drop shock performance than SAC305 and SAC405 [2]-[5]. 
This study includes reliability analysis of a variety of sphere alloys which include low-Ag SAC spheres as well as spheres with dopants, particularly bismuth (Bi) and nickel (Ni). Nickel has shown to increase drop shock reliability of SAC spheres, particularly in the F35 ( $\mathrm{Sn}-1.2 \mathrm{Ag}-0.5 \mathrm{Cu}+0.05 \mathrm{Ni})$ solder alloy [27]. Research has shown that the addition of nickel to SAC solder alloys will improve thermal fatigue performance as well [28].

Bismuth added to lead-free solders as a micro-alloying agent has several benefits as well. These include to lower the solidus temperature, improve the strength of the solder, and to improve wetting and spread of the solder alloy [29]-[31]. However, the effect of Bi addition to SAC solder alloys on drop shock performance is inconclusive, but may improve or decrease drop shock performance depending on the alloy composition. The addition of Bi to SAC305 solder alloys reduces drop shock performance, while the addition of Bi to $\mathrm{SACX}(0.3 \mathrm{Ag})$ has shown to improve its performance [3].

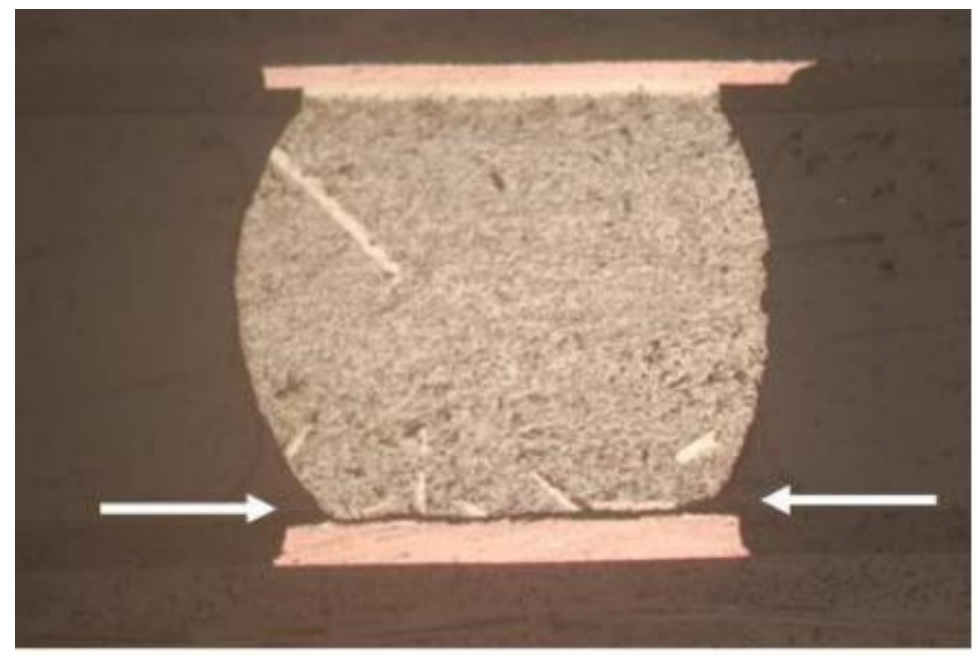

Figure 3. BGA solder joint crack resulting in electrical discontinuity and solder joint failure [17]. 


\subsection{Solder Joint Failure}

One of the most common failure modes for component is an open circuit resulting from solder joint fracture. This begins with an initiation of a crack in the joint, followed by propagation of the crack from cyclic loading. A cross-sectioned BGA solder joint with a complete fracture is seen in Figure 3. Solder joint fracture results from cyclic stresses and strains which damage the solder joint over time. However, these failures are extremely difficult to monitor and track due to the increased miniaturization of many types of electronic packages [32]. This miniaturization makes it very challenging to examine solder joint failures through non-destructive methods, such as X-ray. Instead, detecting solder joint failure is oftentimes done through monitoring resistance of the solder joint or daisy chain [7].

\subsubsection{Solder Joint Failure Criteria}

The proper failure criterion for accelerated life tests must be selected in order for reliability analyses to be accurate. For example, a failure criterion used which is not sensitive enough would result in overestimated reliability life. Societies such as IPC (Association Connecting Electronics Industries) and JEDEC (Solid State Technology Association) publish solder joint failure standards that are used extensively in industry. These standards, which specify solder joint criteria for temperature cycling tests, bend tests, and drop tests, are shown in Table 1. Results of a survey included in Qi et al. show that solder joint failure criteria used by major electronics companies are oftentimes adaptations of these standards as well (see Table 2) [6]. 
Regardless of the type of accelerated life test, solder joint failures are detected through data loggers or event detectors which monitor resistance of a solder joint or daisy chain. Solder joint failure criteria can be defined as either a resistance increase relative to the initial resistance, resistance beyond a specified threshold, or based on characteristics of electrical discontinuity in a solder joint. During thermal cycling, solder joint discontinuity is exhibited through high resistance spikes $(\geq 300 \Omega)$ of a short duration $(\sim 1$ $\mu$ s) [6].

Table 1. Solder joint failure criteria standards [7]

\begin{tabular}{|c|c|c|c|}
\hline \multirow{2}{*}{ Standard } & \multirow{2}{*}{ Test } & \multicolumn{2}{|c|}{ Failure definition } \\
\hline & & Event Detector & Data Logger \\
\hline $\begin{array}{l}\text { IPC-SM-785 } \\
\quad(1992)\end{array}$ & $\begin{array}{l}\text { Temperature } \\
\text { cycling }\end{array}$ & \multicolumn{2}{|c|}{$\begin{array}{l}\text { The } 1^{\text {st }} \text { event of resistance exceeding } 1000 \Omega \text { for lasting } \\
>1 \mu \text { s, followed by }>9 \text { events within } 10 \% \text { of the number } \\
\text { of cycles to initial failure }\end{array}$} \\
\hline $\begin{array}{l}\text { IPC-9701 } \\
(2002) \& \\
\text { IPC-9701A } \\
\quad(2006)\end{array}$ & $\begin{array}{l}\text { Temperature } \\
\text { cycling }\end{array}$ & $\begin{array}{l}\text { The } 1^{\text {st }} \text { event of resistance } \\
\text { exceeding } 1000 \Omega \text { for } \\
\text { lasting }>1 \mu \mathrm{s} \text {, followed by } \\
>9 \text { events within } 10 \% \text { of the } \\
\text { cycles to initial failure }\end{array}$ & $\begin{array}{l}20 \% \text { resistance increase } \\
\text { in } 5 \text { consecutive readings }\end{array}$ \\
\hline $\begin{array}{l}\text { JESD22- } \\
\text { B111 (2003) }\end{array}$ & Drop test & $\begin{array}{c}\text { The } 1^{\text {st }} \text { event of resistance }> \\
1000 \Omega \text { for a period of } \\
>1 \mu \mathrm{s} \text {, followed by } 3 \\
\text { additional such events } \\
\text { during } 5 \text { subsequent drops. }\end{array}$ & $\begin{array}{c}1^{\text {st }} \text { detection of resistance } \\
\text { value of } 100 \Omega \text { if initial } \\
\text { resistance is }<85 \Omega \text {, or } \\
20 \% \text { increase in } \\
\text { resistance if initial } \\
\text { resistance is }>85 \Omega, \\
\text { followed by } 3 \text { additional } \\
\text { such events during } 5 \\
\text { subsequent drops. }\end{array}$ \\
\hline $\begin{array}{l}\text { IPC/JEDEC- } \\
9702(2004)\end{array}$ & Bend test & \multicolumn{2}{|c|}{$\begin{array}{l}20 \% \text { resistance increase. A lower or higher threshold } \\
\text { may be more appropriate, depending upon test } \\
\text { equipment capability and specific daisy-chain design } \\
\text { scheme. }\end{array}$} \\
\hline
\end{tabular}


Table 2. Failure criteria used by major electronics companies [6]

\begin{tabular}{|c|c|}
\hline Company/Organizaion & Criteria Used \\
\hline A & IPC-SM and IPC-9701 \\
\hline B & IPC-9701 \\
\hline C & IPC-SM-785 \\
\hline D & IPC-SM-785 \\
\hline E & Internal standard, but refers to JESD22- \\
\hline F & IPC-SM-785 \\
\hline G & IPC-9701 \\
\hline H & Similar to IPC-9701 \\
\hline
\end{tabular}

A study by Henshall et al. evaluated the thermal fatigue performance of SAC105, Sn-3.5Ag, and SAC305 BGA spheres using three failure criteria: $20 \%$ resistance rise as specified by IPC-9701A, $500 \Omega$ threshold, and infinite resistance (hard open). The study concluded that IPC-9701A was the most sensitive failure criterion of the three for the BGA packages in the study. When IPC-9701A was used, solder joint failure was detected 200 to 500 cycles sooner than for the other two criteria.

\subsection{2 $\bar{X}$ and R Failure Criteria}

The $\bar{X}$ and $\mathrm{R}$ solder joint failure criterion proposed by Pan and Silk defines solder joint failure as a resistance measurement exceeding $k$ times the natural variation [7]. This methodology stems from the traditional $\bar{X}$ and $\mathrm{R}$ (range) control charts from statistical process control, originally developed by Walter Shewhart [33]. Other failure criteria used in industry do not consider the natural variation by random causes, such as the defined $20 \%$ resistance increase of IPC-9701A. Instead, the $\bar{X}$ and R solder joint failure criterion detects solder joint cracks by considering resistance increases exceeding threshold which is based on the natural variation. 
The $\bar{X}$ chart monitors the process mean, while the $\mathrm{R}$ chart monitors the process variability. When applied to solder joint failure, a resistance measurement above the upper control limit (UCL) indicates solder joint failure. The control limits of $\bar{X}$ chart are defined as follows:

$$
\begin{aligned}
& \text { Control Limits : } \overline{\bar{X}} \pm \frac{k \sigma}{\sqrt{n}} \\
& \text { Where } \overline{\bar{X}} \text { is the average resistance, } \\
& \sigma=\text { standard deviation of resistance due to natural variation, } \\
& n=\text { rational subgroup size, and } \\
& k=\text { desired number of standard deviations from the mean. }
\end{aligned}
$$

The recommended $k$ value is 3 to 10 . A smaller $\mathrm{k}$ value would detect solder joint failure as early as possible, while a larger $\mathrm{k}$ value would minimize false detection (Type II error). For the $3 \sigma$ control chart which is standard in industry, $k$ is set to 3 . The control limits of $\mathrm{R}$ chart are defined as:

Control Limits: $L C L_{R}=D_{3} \bar{R}$ and $U C L_{R}=D_{4} \bar{R}$

Where $R=X_{\max }-X_{\min }$ (sample range), and

$D_{3}$ and $D_{4}$ are sample anti-biasing constants.

The study by Pan and Silk included an experiment which tested 39 components in three different package platforms. After cross-sectioning of the solder joints, the study concluded that a complete crack of an interconnection occurs when $\mathrm{k}$ is 10 , which proves 
the validity. However, using a smaller $\mathrm{k}$ value would result in more sensitive failure criteria, which would minimize "false positive" failure detection (Type I error). 


\section{Chapter 3. Low-Silver BGA Assembly Study}

The low-silver BGA study, an industry consortium study by Henshall et al., was undertaken to characterize the influence of solder alloy type and reflow parameters on the reliability life of the BGA assemblies [8]. The first phase of the study focuses on the development of reflow profiles and their effect on mixing levels of the reflowed solder joint. The results of Phase I of the low-silver BGA study were used in the development of the experimental design for Phase II-the assessment of thermal fatigue performance of low-silver BGA components through accelerated thermal cycling.

\subsection{Low-Silver BGA Experimental Setup: Accelerated Thermal Cycling}

Accelerated thermal cycling data analyzed in this study is from the low-silver BGA study by Henshall et al. [8]. The experimental materials from the low-silver BGA and procedures necessary for the understanding of study are described in this section. Additional details from the ATC procedure, test vehicles, and board layouts are described in the sixth publication for the low-silver BGA study by Henshall, et al. [34]. The paste alloys used for the BGA assemblies were $\mathrm{SnPb}$ and $\mathrm{SAC} 305$. The following sphere alloys were investigated in the study:

- $\operatorname{SACX} 0307(\mathrm{Sn}-0.3 \mathrm{Ag}-0.7 \mathrm{Cu}+\mathrm{Bi}+\mathrm{X})$,

- $\mathrm{SAC} 105(\mathrm{Sn}-1.0 \mathrm{Ag}-0.5 \mathrm{Cu})$, 
- $\operatorname{LF} 35(\mathrm{Sn}-1.2 \mathrm{Ag}-0.5 \mathrm{Cu}+0.05 \mathrm{Ni})$,

- $\mathrm{SAC} 205(\mathrm{Sn}-2.0 \mathrm{Ag}-0.5 \mathrm{Cu})$,

- SAC 305 (Sn-3.0Ag-0.5Cu), the Pb-free baseline, and

- $\mathrm{Sn}-\mathrm{Pb}(\mathrm{Sn}-37 \mathrm{~Pb}), \mathrm{Sn}-\mathrm{Pb}$ baseline.

Also, four different BGA package types were studied:

- $0.05 \mathrm{~mm}$ pitch ChipArray Thin Core BGA, $132 \mathrm{I} / \mathrm{O}$; solder ball volume of $0.014 \mathrm{~mm}^{3}$.

- $0.80 \mathrm{~mm}$ pitch ChipArray BGA, $288 \mathrm{I} / \mathrm{O}$; solder ball volume of $0.051 \mathrm{~mm}^{3}$,

- $1.00 \mathrm{~mm}$ pitch Plastic BGA, $324 \mathrm{I} / \mathrm{O}$; solder ball volume of $0.131 \mathrm{~mm}^{3}$, and

- $1.27 \mathrm{~mm}$ pitch SuperBGA, $600 \mathrm{I} / \mathrm{O}$; solder ball volume of $0.230 \mathrm{~mm}^{3}$.

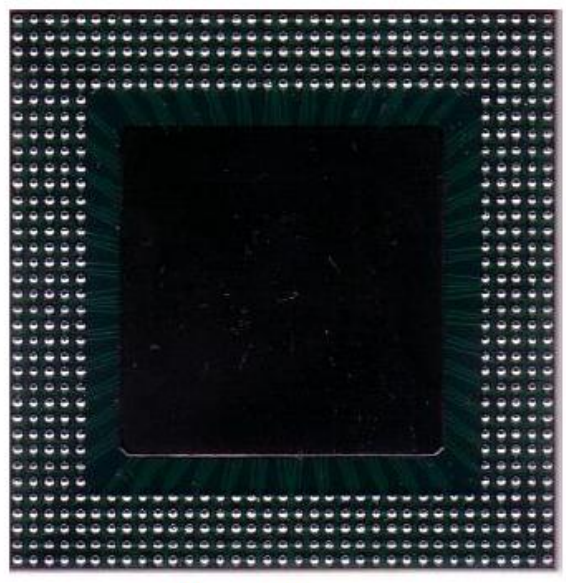

SBGA600

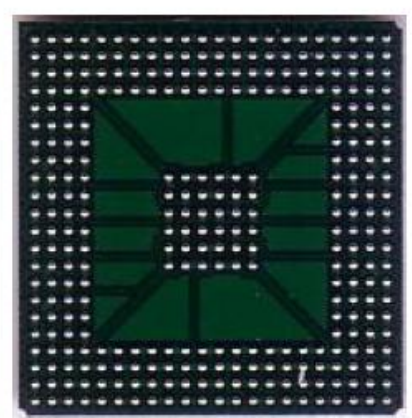

PBGA324

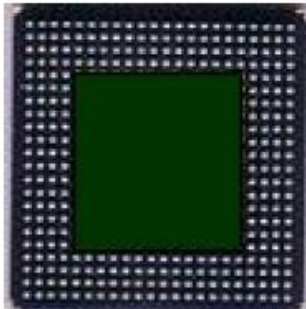

CABGA288

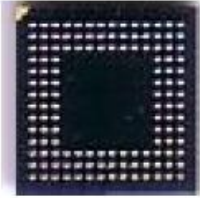

CTBGA132

Figure 4. BGA package types [37].

These package types are shown in Figure 4. From now on, these package types will be identified by their pitch. The accelerated thermal cycling (ATC) for the low-silver BGA study included two ATC conditions as specified by IPC-9701A [35]: 
- IPC-9701A condition $\mathrm{TC} 1: 0^{\circ} \mathrm{C}$ to $100^{\circ} \mathrm{C}$ with 10 minute ramps and dwells, and

- IPC-9701A condition $\mathrm{TC} 3:-40^{\circ} \mathrm{C}$ to $125^{\circ} \mathrm{C}$ with 16.5 minute ramps and 10 minute dwells.

The test was terminated at 10,102 cycles for the $0^{\circ} \mathrm{C}$ to $100^{\circ} \mathrm{C}$ temperature cycling range (TCR), and at 3,556 for the $-40^{\circ} \mathrm{C}$ to $125^{\circ} \mathrm{C}$ temperature cycling range (TCR) [36]. The full experimental matrix is seen in Table 3. A total of 20 packages were tested for each treatment, or "cell".

Table 3. Accelerated thermal cycling (ATC) experimental matrix for the low-silver BGA study [36].

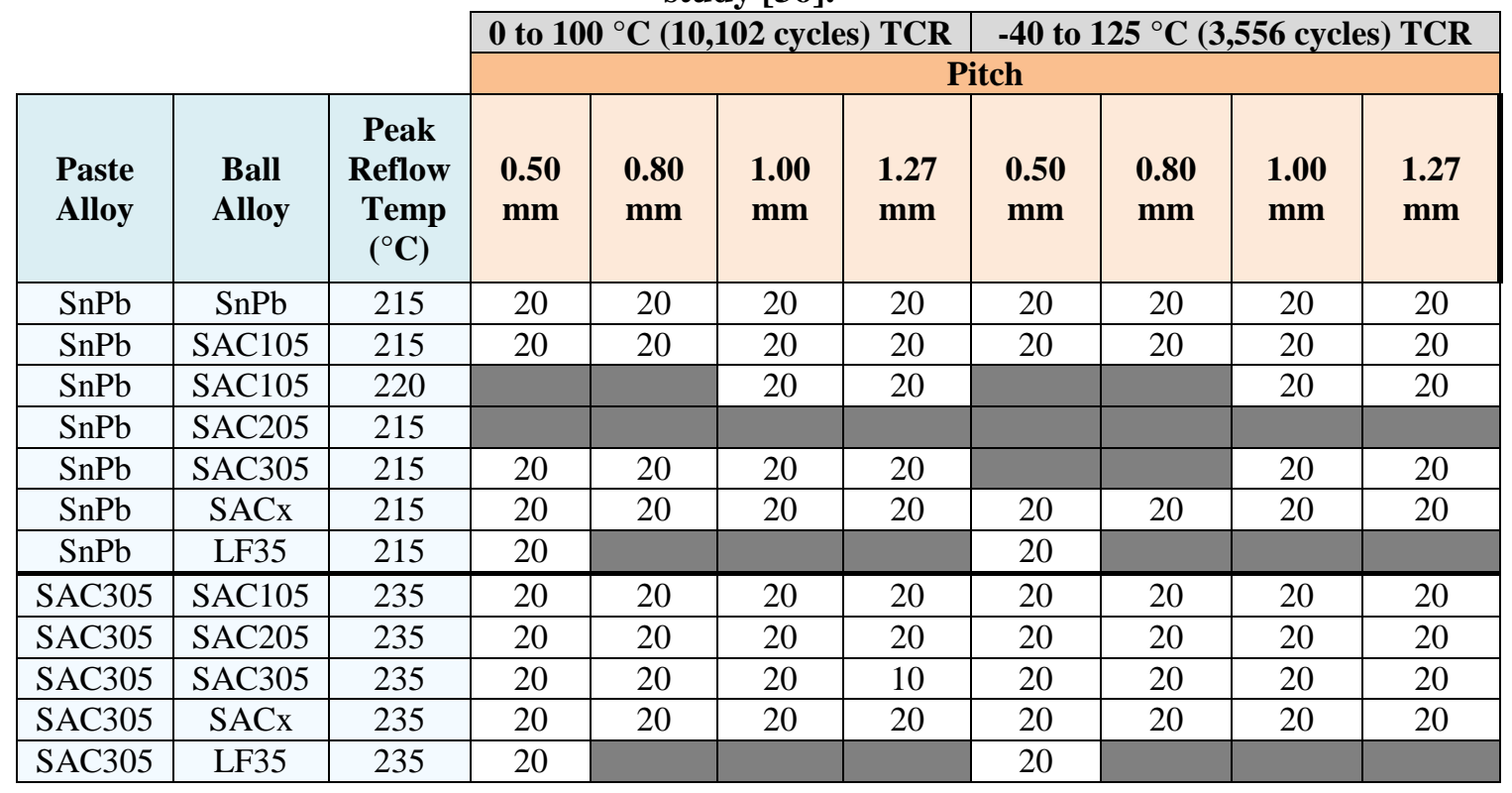




\section{Chapter 4. Analysis and Results: Comparison of Four Failure Criteria}

The accelerated thermal cycling data from the Low-Ag BGA Assembly Study were analyzed accordingly:

1. Failure detection and failure criteria comparison using four failure criteria: Cycles-to-failure for the low-Ag BGA accelerated thermal cycling data was determined using four failure criteria. The sensitivity of the four failure criteria was then compared.

2. Reliability analysis of low-Ag BGA assembly accelerated thermal cycling (ATC) data: The failure data for the $\bar{X}$ and $\mathrm{R}$ failure criteria was fit to the Weibull lifetime distribution in order to estimate the Weibull characteristic life $(\alpha)$ and slope $(\beta)$ parameters. Analysis of variance (ANOVA) was used to see if package construction and solder joint composition had a statistically significant effect on the characteristic life and slope of the BGA assemblies.

This chapter includes the analysis and results for the failure detection and failure criteria comparison, while the following chapter includes the analysis and results of the reliability analysis. 


\subsection{Comparison of Four Failure Criteria}

The objective of this study is to compare the effect of failure criteria in reliability life estimation for low-silver BGA data. The four failure criteria are:

1. $\bar{X}$ and R chart method

2. IPC-9701A: Cycle exceeding a $20 \%$ increase in resistance, where $R(T)>1.2 \cdot R_{0}(T)$, and $R_{0}(T)=$ resistance measured during the first cycle at temperature $\mathrm{T}$.

3. Resistance $>500 \Omega$ : Cycle of first resistance reading greater than $500 \Omega$

4. Infinite Resistance: Cycle of first infinite resistance reading

\subsubsection{Selection of Failure Criteria}

The failure criteria selected to evaluate the low-silver BGA data were selected from the failure criteria used in the thermal fatigue study of SAC105, Sn-3.5Ag, and SAC305 BGA by Henshall et al.[35]. Henshall et al. used the IPC-9701A failure criteria, $500 \Omega$ threshold, and infinite resistance (hard open) as failure criteria, and concluded that IPC9701A was the most sensitive failure criterion of the three. The same failure criteria were selected for this study in order to compare this conclusion to a different and larger set of accelerated thermal cycling data (from the low-silver BGA study). These three failure

criteria were compared with the $\bar{X}$ and $\mathrm{R}$ chart method proposed by Pan and Silk. Prior to this study, the $\bar{X}$ and $\mathrm{R}$ failure criterion had not been applied to any other accelerated testing data beyond the 39 packages evaluated in the study by Pan and Silk. 


\subsection{2 $\quad \bar{X}$ and $\mathrm{R}$ chart Failure Criterion}

The methodology for the $\bar{X}$ and $\mathrm{R}$ failure criterion proposed by Pan and Silk is described in the Literature Review. $\bar{X}$ and $\mathrm{R}$ charts were created for each component in the lowsilver BGA study (total of 720 connections) using JMP software. The control limits of $\bar{X}$ chart are defined as:

Control Limits : $\overline{\bar{X}} \pm \frac{k \sigma}{\sqrt{n}}$

Where $\overline{\bar{X}}$ is the average resistance of the first 40 cycles, $\sigma=$ standard deviation of resistance due to natural variation, and $n=$ rational subgroup size (the average number of readings in each temperature cycle).

In this study, $\mathrm{k}=3$ is used, which minimizes "false positive" failure detection. A $\mathrm{k}$ value of 3 is the accepted industry standard for statistical process control. When $k=3$, the probability of an encountering an observation beyond three standard deviations from the center line is $0.3 \%$. Therefore, a point outside the control limits indicates the process has shifted and is no longer in control [11]. The control limits of $\mathrm{R}$ chart are defined as:

Control Limits: $L C L_{R}=D_{3} \bar{R}$ and $U C L_{R}=D_{4} \bar{R}$

Where $R=X_{\max }-X_{\min }$ (sample range), and

$D_{3}$ and $D_{4}$ are sample anti-biasing constants. 
A control chart for a single BGA package ( $\mathrm{SnPb}$ ball alloy, SAC105 paste alloy, 1.0mm pitch, peak reflow temperature of $220^{\circ} \mathrm{C}$, and temperature cycling range of 0 to $100^{\circ} \mathrm{C}$ ) is shown in Figure 5. The $\bar{X}$ chart indicates failure 5375 cycles.

\subsubsection{IPC-9701A, 500 Ohm, and Infinite Resistance Failure Criteria}

\section{$\bar{X}$ Chart}
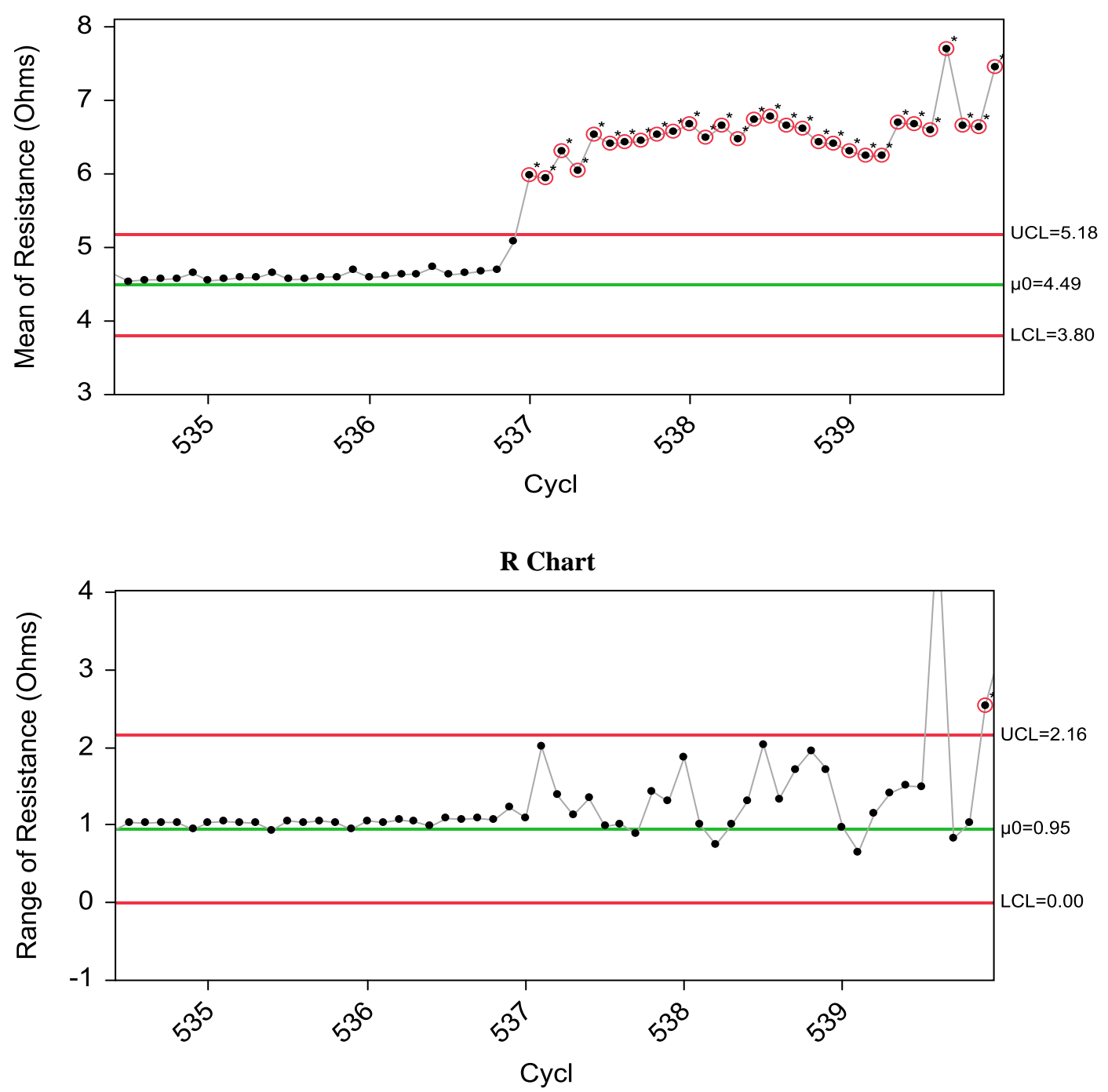

Figure 5. $\bar{X}$ and $\mathrm{R}$ chart for a BGA package 
Throughout the accelerated thermal cycling of the packages, the daisy chain resistance was monitored continuously. The data acquisition software detected failure from the IPC9701A standard for a $20 \%$ increase in resistance from the initial value. The resistance was monitored for the remainder of the accelerated thermal cycling $(10,102$ cycles for the 0 to $100{ }^{\circ} \mathrm{C}$ temperature cycling range, and 3,556 cycles for the -40 to $125{ }^{\circ} \mathrm{C}$ temperature cycling range). From this data, the cycles to failure for the $500 \mathrm{Ohm}$ and Infinite Resistance failure criteria were identified.

\subsection{Results: Comparison of Failure Criteria}

Failure data (cycles-to-failure) for the $\bar{X}$ and R, IPC-9701A, $500 \Omega$, and Infinite Resistance failure criteria are seen in Appendix A. The number of components meeting each failure criterion is shown in Table 4. A total of 720 components were analyzed for both temperature cycling ranges. Any package that did not meet a failure criterion was considered as right-censored for the reliability analysis. Appendix A includes this rightcensored data, which are indicated by having no failure (n.f.).

Table 4. Number of components meeting each failure criterion with \% out of 720 total components

\begin{tabular}{|l|c|c|}
\cline { 2 - 3 } \multicolumn{1}{c|}{} & $\begin{array}{c}\mathbf{0}^{\circ} \mathbf{C} \text { to } 100 \\
(\mathbf{1 0 , 1 0 2} \text { cycles })\end{array}$ & $\begin{array}{c}-40^{\circ} \mathbf{C} \text { to } 125 \\
(\mathbf{3 , 5 5 6} \text { cycles })\end{array}$ \\
\hline $\bar{X}$ and R & $687(95 \%)$ & $710(99 \%)$ \\
\hline IPC-9701A & $687(95 \%)$ & $710(99 \%)$ \\
\hline $\mathbf{5 0 0}$ Ohm & $687(95 \%)$ & $710(99 \%)$ \\
\hline Infinite Resistance & $629(88 \%)$ & $710(99 \%)$ \\
\hline
\end{tabular}

A graph of the cycles of failure for a single package ( $\mathrm{SnPb}$ ball alloy, $\mathrm{SAC105}$ paste alloy, $1.0 \mathrm{~mm}$ pitch, peak reflow temperature of $220^{\circ} \mathrm{C}$, and temperature cycling range of 0 to $100^{\circ} \mathrm{C}$ ) is shown in Figure 6 For this BGA package, both $\bar{X}$ and R failure 
criterion and IPC-9701A detected solder joint failure at 5,375 cycles, while $500 \Omega$ resistance threshold detected failure at 5,456 cycles and Infinite Resistance failure criteria detected failure at 5,504 cycles. Thus, the $\bar{X}$ and $\mathrm{R}$ and IPC-9701A failure criteria are more sensitive than the $500 \Omega$ resistance threshold and Infinite Resistance failure criterion for this package. However, most packages exhibited this general relationship amongst the failure criterion. In general, the $\bar{X}$ and R and IPC-9701A criteria had very similar cycles to failure while being more sensitive than the $500 \Omega$ resistance threshold and Infinite Resistance failure criteria.

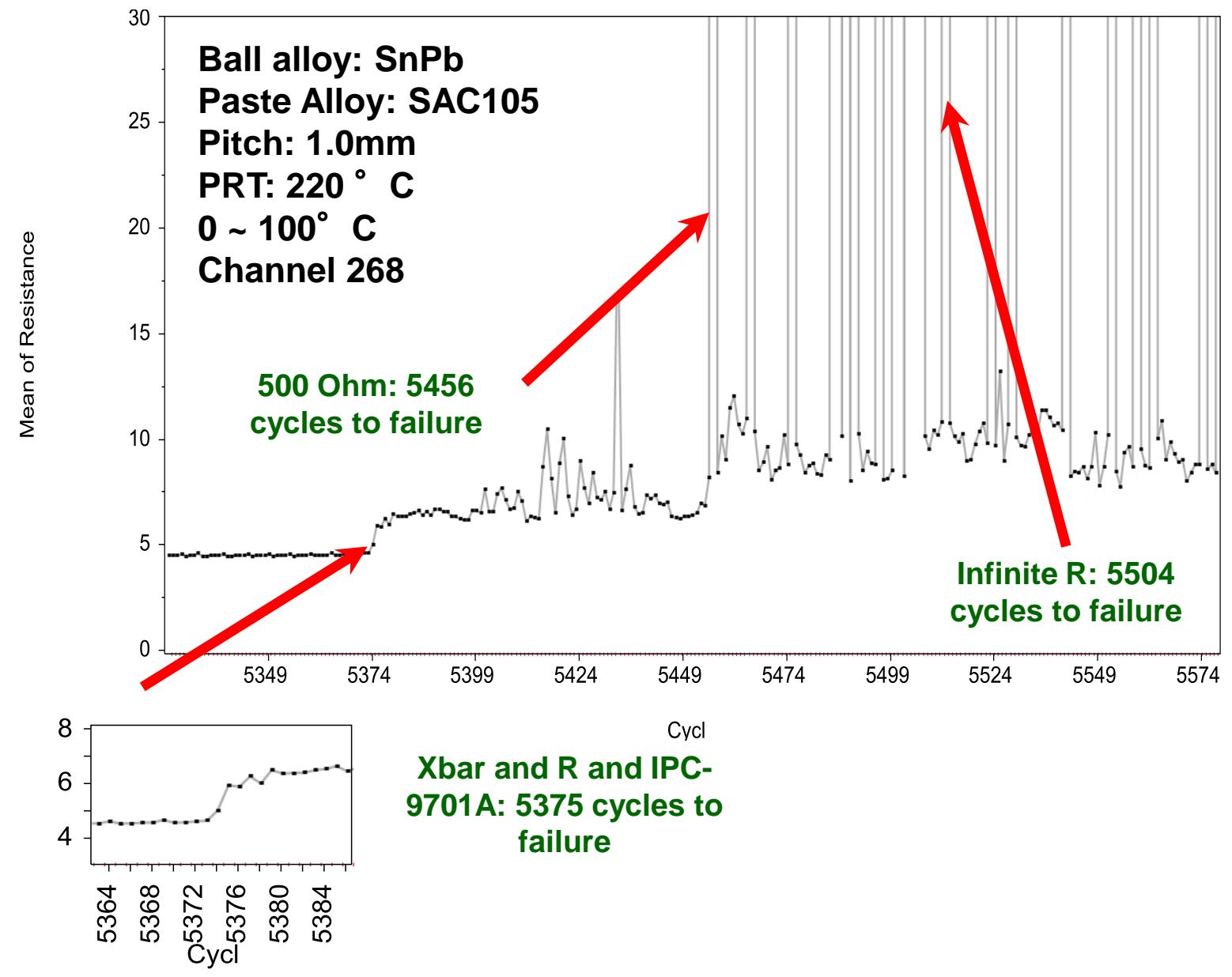

Figure 6. Cycles to failure of four failure criteria for one package 
Table 5 illustrates that $\bar{X}$ and R failure criterion and IPC-9701A detected solder joint failure at the same cycles-to-failure in most cases. The $\bar{X}$ and $\mathrm{R}$ failure criterion detected solder joint failure marginally sooner than IPC-9701A, with an average of 1.76 cycles earlier detection. Table 6 shows that $\bar{X}$ and R and IPC-9701A consistently detected failure sooner than $500 \Omega$ resistance threshold and Infinite Resistance failure criteria. The $\bar{X}$ and $\mathrm{R}$ method detected failure on average 334 cycles or $12.9 \%$ of time-tofailure earlier than $500 \Omega$ failure criterion for 0 to $100^{\circ} \mathrm{C}$ data, and 94 cycles or $10.4 \%$ of time-to-failure earlier for -40 to $125^{\circ} \mathrm{C}$ data. In addition, $\bar{X}$ and $\mathrm{R}$ failure criterion detected failure on average 822 cycles or $23.4 \%$ of time-to-failure earlier than Infinite Resistance failure criterion for 0 to $100^{\circ} \mathrm{C}$ data, and 227 cycles or $18.6 \%$ of time-tofailure earlier for -40 to $125^{\circ} \mathrm{C}$ data.

Table 5. $\bar{X}$ and R failure criterion compared to IPC-9701A

\begin{tabular}{|c|c|c|c|}
\cline { 2 - 4 } \multicolumn{1}{c|}{} & $\begin{array}{c}\text { \% Earlier } \\
\text { Detection }\end{array}$ & \% Same Detection & \% Later Detection \\
\hline $\mathbf{0}^{\circ} \mathbf{C}$ to $\mathbf{1 0 0}{ }^{\circ} \mathbf{C}$ TCR & 21.7 & 73.1 & 5.2 \\
\hline $\mathbf{- 4 0}^{\circ} \mathbf{C}$ to $\mathbf{1 2 5}^{\circ} \mathbf{C}$ TCR & 38.2 & 61.1 & 0.7 \\
\hline
\end{tabular}

Table 6. Average cycles to failure (\% Total Cycles*) for four failure criteria

\begin{tabular}{|l|c|c|c|c|}
\cline { 2 - 5 } \multicolumn{1}{c|}{} & $\bar{X} \boldsymbol{\&} \mathbf{R}$ & IPC-9701A & $\mathbf{5 0 0} \boldsymbol{\Omega}$ & Infinite Resistance \\
\hline $\mathbf{0}$ to $\mathbf{1 0 0}{ }^{\circ} \mathbf{C}$ TCR & $3883(38.4 \%)$ & $3886(38.4 \%)$ & $4217(41.7 \%)$ & $4705(46.6 \%)$ \\
\hline $\mathbf{- 4 0}$ to $\mathbf{1 2 5} \mathbf{C}^{\circ} \mathbf{C} \mathbf{T C R}$ & $1515(42.6 \%)$ & $1516(42.6 \%)$ & $1609(45.2 \%)$ & $1743(49.0 \%)$ \\
\hline
\end{tabular}

Table 7 and Table 8 show the response values for Weibull characteristic life and slope parameter estimates for each treatment, respectively. Although there was no replication in the responses, each characteristic life and slope parameter was estimated from the failure data of 20 packages. 
Table 7. Weibull characteristic life values for each treatment.

\begin{tabular}{|c|c|c|c|c|c|c|c|c|}
\hline \multirow{3}{*}{ Ball/Paste } & \multicolumn{4}{|c|}{0 to $100{ }^{\circ} \mathrm{C}$ TCR $(10,102$ cycles $)$} & \multicolumn{4}{|c|}{-40 to $125{ }^{\circ} \mathrm{C}(3556$ cycles $) \mathrm{TCR}$} \\
\hline & \multicolumn{8}{|c|}{ Pitch } \\
\hline & $0.5 \mathrm{~mm}$ & $0.8 \mathrm{~mm}$ & $1.0 \mathrm{~mm}$ & $1.27 \mathrm{~mm}$ & $0.5 \mathrm{~mm}$ & $0.8 \mathrm{~mm}$ & $1.0 \mathrm{~mm}$ & $1.27 \mathrm{~mm}$ \\
\hline $\mathrm{SnPb}$ & 1825.77 & 1065.50 & 2162.69 & 3742.99 & 1326.73 & 1293.40 & 1818.73 & 2388.38 \\
\hline $\mathrm{SAC} 305-\mathrm{SnPb}$ & 3176.21 & 2809.34 & 6485.70 & 10574.84 & 1449.72 & 1234.01 & 1657.65 & 2240.17 \\
\hline $\mathrm{SAC} 105-\mathrm{SnPb}$ & 2866.70 & 1748.73 & 4856.77 & 7141.78 & 1474.99 & 1512.24 & 1517.76 & 2190.30 \\
\hline $\mathrm{SACX}-\mathrm{SnPb}$ & 3099.28 & 1601.68 & 3808.37 & 7672.22 & 1319.55 & 1272.37 & 1721.89 & 2605.52 \\
\hline SAC305 & 3671.79 & 3320.03 & 5660.81 & 11214.19 & 1235.30 & 1037.86 & 1735.66 & 2646.72 \\
\hline SAC105-SAC305 & 3105.33 & 2069.59 & 4022.67 & 7972.19 & 1498.92 & 1472.08 & 1525.58 & 2708.53 \\
\hline SACX-SAC305 & 2975.16 & 2088.34 & 3198.30 & 5109.12 & 1337.04 & 1131.00 & 1543.17 & 2237.56 \\
\hline SAC205-SAC305 & 3394.76 & 2583.50 & 4449.32 & 6348.58 & 1479.59 & 1546.13 & 1480.78 & 2753.35 \\
\hline
\end{tabular}

Table 8. Weibull slope values for each treatment

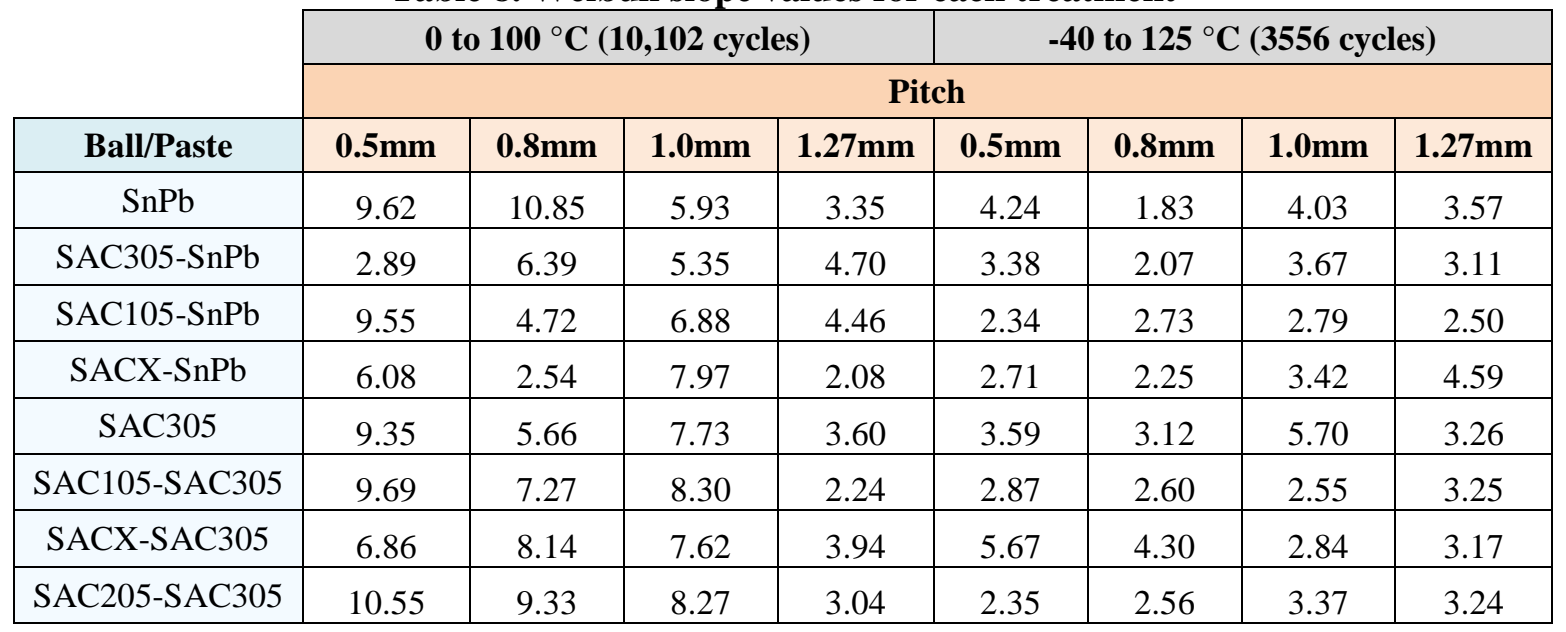




\section{Chapter 5. Analysis and Results: Reliability analysis of low-Ag BGA ATC data}

The reliability analysis of the low-Ag BGA data was performed using the $\bar{X}$ and R failure data. First, the Weibull life distribution was selected for the analysis from several distributions through the comparison of AIC values. The Weibull parameters (characteristic life $\alpha$ and slope $\beta$ ) were then estimated for each treatment. An analysis of variance (ANOVA) was performed to determine the significant factors which affect these Weibull parameters for the low-silver BGA solder joints.

\subsection{Reliability Life Distribution Fitting}

The failure data for each treatment "cell" was fit to every life distribution available on the life distribution platform using JMP statistical software. Components which did not fail by the end of the thermal cycling were right-censored. The appropriate life distribution for the failure data was selected through the comparison of the Akaike information criterion (AIC) values for the following goodness-of-fit measurement with the following equation: $A I C=2 k-2 \ln (L)$, where $k$ is the number of parameters in the model and $\underline{L}$ is the maximum likelihood function of the model. For model selection from multiple models, the preferred model has the minimum AIC value.

The AIC values for all treatments were averaged for both temperature cycling ranges. The two lifetime distribution models with the minimum average AIC values were the two-parameter Weibull distribution and Lognormal distribution. The average AIC values were very close, with the Lognormal providing a slightly better fit for the $0{ }^{\circ} \mathrm{C}$ to 
$100{ }^{\circ} \mathrm{C}$ temperature cycling range and the Weibull distribution providing a slightly better fit for the $-40{ }^{\circ} \mathrm{C}$ to $125{ }^{\circ} \mathrm{C}$ temperature cycling range (See Table 9). Although this indicates that either would have been suitable to model the data, the Weibull distribution was selected.

Table 9. Average AIC values for Weibull and Lognormal distributions for each temperature cycling range

\begin{tabular}{|c|c|c|c|}
\hline Temperature Cycling Range & Distribution & $\begin{array}{c}\text { Average } \\
\text { AIC }\end{array}$ & Better Fit (Count) \\
\hline \multirow{2}{*}{$0{ }^{\circ} \mathrm{C}$ to $100{ }^{\circ} \mathrm{C}$} & Weibull & 293.89 & 13 \\
\cline { 2 - 4 } & Lognormal & 293.09 & 23 \\
\hline \multirow{2}{*}{$-40{ }^{\circ} \mathrm{C}$ to $125^{\circ} \mathrm{C}$} & Weibull & 303.8 & 20 \\
\cline { 2 - 4 } & Lognormal & 304.42 & 16 \\
\hline
\end{tabular}

\subsubsection{Weibull Parameter Estimation}

Table 10 includes Weibull parameter estimates (the characteristic life $\alpha$ and slope $\beta$ ) for one "cell" treatment with a ball alloy of $\mathrm{SnPb}$, paste alloy of SAC105 pitch of $1.0 \mathrm{~mm}$, peak reflow temperature of $220^{\circ} \mathrm{C}$, and thermal cycling range of 0 to $100^{\circ} \mathrm{C}$. Figure 7 shows the Weibull plots for each failure criterion of the treatment. The Weibull characteristic life and slope are used as response variables for the ANOVA analysis which is described in the next section.

Table 10. Weibull parameter estimation for one cell

\begin{tabular}{|c|c|c|}
\hline Failure Criteria & Parameter & Parameter Est. \\
\hline \multirow{2}{*}{ and R } & Weibull $\alpha$ & 4646.78 \\
\cline { 2 - 3 } & Weibull $\beta$ & 6.78 \\
\hline \multirow{2}{*}{ IPC-9701A } & Weibull $\alpha$ & 4649.71 \\
\cline { 2 - 3 } & Weibull $\beta$ & 6.77 \\
\hline \multirow{2}{*}{$500 \Omega$} & Weibull $\alpha$ & 5362.38 \\
\cline { 2 - 3 } Infinite R & Weibull $\beta$ & 7.37 \\
\hline \multirow{2}{*}{} & Weibull $\alpha$ & 5455.45 \\
\cline { 2 - 3 } & Weibull $\beta$ & 7.93 \\
\hline
\end{tabular}




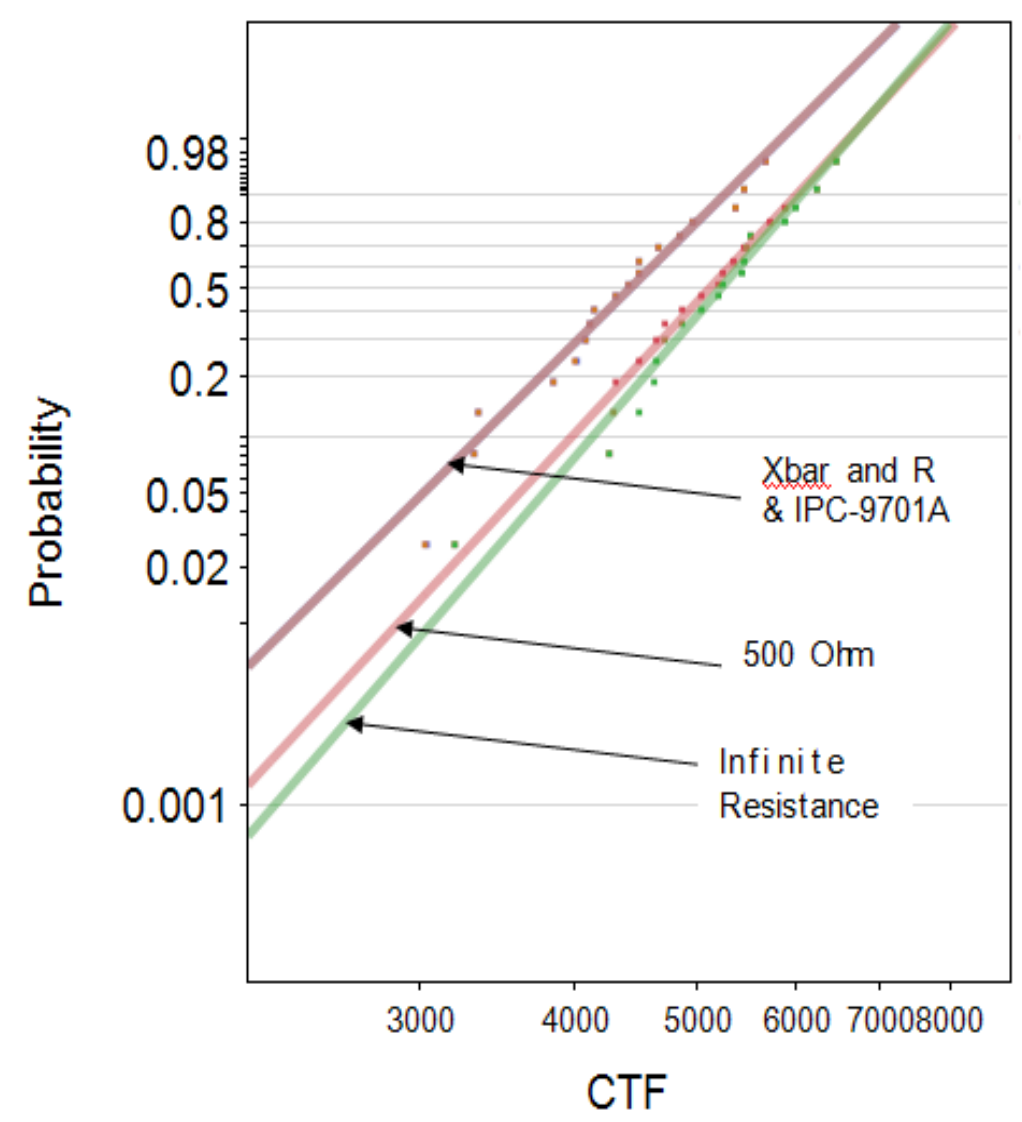

Figure 7. Weibull plot for one cell using four failure criteria

\subsection{ANOVA using $\bar{X}$ and R Failure Criterion}

Analysis of variance was used to determine the significant factors which affect the Weibull characteristic life and slope of the low-silver BGA solder joints for both temperature cycling ranges. Weibull parameter estimates from the $\bar{X}$ and $\mathrm{R}$ failure criterion were used in the ANOVA, because the $\bar{X}$ and R and IPC-9701A failure criteria were the most sensitive of the four studied, but provided very similar cycles to failure and Weibull parameter estimates. 


\subsubsection{Experimental Design}

The original experimental matrix for the accelerated thermal cycling for the low-silver BGA study is described in the literature review. Varied in the original experimental matrix for the accelerated thermal cycling were ball alloy, paste alloy, peak reflow temperature, and pitch (see Table 3). Peak reflow temperature was removed as a factor for the analysis, and the ball alloy and paste alloy were consolidated into one factor. In addition, certain treatments were removed to create a balanced model. The resulting design was a two-way ANOVA for each of the four response variables: Weibull characteristic life $(\alpha)$ for 0 to $100{ }^{\circ} \mathrm{C}$ and -40 to $125{ }^{\circ} \mathrm{C}$ temperature cycling ranges and Weibull slope ( $\beta$ ) for 0 to $100{ }^{\circ} \mathrm{C}$ and -40 to $125^{\circ} \mathrm{C}$ temperature cycling ranges.

\subsubsection{Pitch (BGA package type)}

The other factor analyzed was BGA package type, which is identified by the pitch of the package type. To review, package types included in the accelerated thermal cycling experiment:

- $1.27 \mathrm{~mm}$ pitch SuperBGA, $600 \mathrm{I} / \mathrm{O}$; solder ball volume of $0.230 \mathrm{~mm}^{3}$,

- $\mathrm{mm}$ pitch Plastic BGA, $324 \mathrm{I} / \mathrm{O}$; solder ball volume of $0.131 \mathrm{~mm}^{3}$,

- $0.8 \mathrm{~mm}$ pitch ChipArray BGA, $288 \mathrm{I} / \mathrm{O}$; solder ball volume of $0.051 \mathrm{~mm}^{3}$, and

- $0.5 \mathrm{~mm}$ pitch ChipArray Thin Core BGA, $132 \mathrm{I} / \mathrm{O}$; solder ball volume of $0.014 \mathrm{~mm}^{3}$.

Both factors were considered nominal. The response variables were Weibull characteristic life $(\alpha)$ and slope $(\beta)$. Significant factors were identified using a p-value 
approach. Further, a Tukey's test of multiple comparisons was conducted for significant factors.

\subsubsection{Paste Alloy and Ball Alloy Consolidation}

The purpose of the reflow process for BGA assemblies is to melt the solder ball alloy into the solder paste, which attaches the surface mount components to a printed circuit board (PCB) and creates electrical continuity. Although complete mixing of the solder alloy and paste alloy is not necessary to create electrical continuity, the experiment in Phase I of the low-silver BGA study identified the factors which affect the level of mixing for the solder joint after reflow. The results of this experiment were used in the selection of peak reflow temperatures for the BGA assemblies used in the accelerated thermal cycling tests. Because it is assumed that appropriate levels of solder paste and solder ball mixing were achieved, the paste and ball alloy were consolidated into one factor (See Table 11) for ANOVA.

Table 11. Ball alloy and paste alloy consolidation

\begin{tabular}{|c|c|c|}
\hline Ball Alloy & Paste Alloy & Ball/Paste \\
\hline $\mathrm{SnPb}$ & $\mathrm{SnPb}$ & $\mathrm{SnPb}$ \\
\hline SAC305 & $\mathrm{SnPb}$ & SAC305-SnPb \\
\hline SAC105 & $\mathrm{SnPb}$ & SAC105-SnPb \\
\hline SACX & $\mathrm{SnPb}$ & SACX-SnPb \\
\hline SAC305 & SAC305 & SAC305 \\
\hline SAC105 & SAC305 & SAC105-SAC305 \\
\hline SACX & SAC305 & SACX-SAC305 \\
\hline SAC205 & SAC305 & SAC205-SAC305 \\
\hline
\end{tabular}

\subsubsection{Peak Reflow Temperature}

Because peak reflow temperature for the BGA assemblies were chosen based on the results of Phase I of the low-silver BGA study, peak reflow temperature was not 
considered a factor for the ANOVA analysis. The peak reflow temperature for the solder joints with SAC305 paste alloy were consistent at $235^{\circ} \mathrm{C}$. The peak reflow temperature for solder joints with $\mathrm{SnPb}$ paste alloy was $215^{\circ} \mathrm{C}$ with the exception of $1.0 \mathrm{~mm}$ and $1.27 \mathrm{~mm}$ pitch BGAs, which were also tested at $215^{\circ} \mathrm{C}$ and $220^{\circ} \mathrm{C}$. However, failure data from these assemblies were ultimately removed for the purpose of this ANOVA (see next section).

\subsubsection{Removal of Treatments for a Balanced ANOVA}

In order to create a balanced model, treatments which included data for some BGA package types (pitches) but not all were removed for the ANOVA. This includes the following treatments from both temperature cycling ranges:

- $\quad 1.0 \mathrm{~mm}$ and $1.27 \mathrm{~mm}$ pitch, $\mathrm{SnPb}$ paste alloy, SAC105 ball alloy, and peak reflow temperature of $220^{\circ} \mathrm{C}$,

- $\quad 0.5 \mathrm{~mm}$ pitch, $\mathrm{SnPb}$ paste alloy, LF ball alloy, peak reflow temperature of $215^{\circ} \mathrm{C}$, and

- $\quad 0.5 \mathrm{~mm}$ pitch, SAC305 paste alloy, LF35ball alloy, peak reflow temperature of $215^{\circ} \mathrm{C}$.

\subsubsection{Final Experimental Matrix}

One factor included in the ANOVA are Ball/Paste with the following levels: $\mathrm{SnPb}$, SAC305-SnPb，SAC105-SnPb，SACX-SnPb，SAC305，SAC105-SAC305，SACXSAC305, and SAC205-SAC305. The other factor included in the analysis was package construction (pitch) with the following levels: $0.5 \mathrm{~mm}, 0.8 \mathrm{~mm}, 1.0 \mathrm{~mm}, 1.27 \mathrm{~mm}$. 
Response variables are the Weibull characteristic life and slope for both temperature cycling ranges $\left(0\right.$ to $100{ }^{\circ} \mathrm{C}$ and -40 to $\left.125^{\circ} \mathrm{C}\right)$.

Table 12 shows the final experimental matrix with the number of BGA packages used in the estimation of the Weibull $\alpha$ and Weibull $\beta$ for ANOVA analysis. Although there was no replication in the responses for each treatment, each characteristic life and slope parameter was estimated from the failure data of 20 packages. The parameter estimates for each treatment are shown in the Results section.

\subsubsection{ANOVA Hypotheses}

The ANOVA will test the following hypotheses for the Weibull characteristic life for the 0 to $100{ }^{\circ} \mathrm{C}$ temperature cycling range:

\section{Factor A (Ball/Paste)}

$\mathrm{H}_{0(\mathrm{~A})}: \mu_{\mathrm{A} 1}=\mu_{\mathrm{A} 2}=\mu_{\mathrm{A} 3}=\mu_{\mathrm{A} 4}=\mu_{\mathrm{A} 5}=\mu_{\mathrm{A} 6}=\mu_{\mathrm{A} 7}=\mu_{\mathrm{A} 8}$

$\mathrm{H}_{\mathrm{A}(\mathrm{A})}$ : at least one pair of the above is not equal

Table 12. Number of components for estimation of Weibull characteristic life and slope for each treatment

\begin{tabular}{|c|c|c|c|c|c|c|c|c|}
\hline & & & & & \multirow{2}{*}{\multicolumn{4}{|c|}{-40 to $125^{\circ} \mathrm{C}$ TCR $(3556$ cycles) }} \\
\hline & \multicolumn{4}{|c|}{0 to $100{ }^{\circ} \mathrm{C}$ TCR $(10,102$ cycles $)$} & & & & \\
\hline & \multicolumn{8}{|c|}{ Pitch } \\
\hline Ball/Paste & $0.5 \mathrm{~mm}$ & $0.8 \mathrm{~mm}$ & $1.0 \mathrm{~mm}$ & $1.27 \mathrm{~mm}$ & $0.5 \mathrm{~mm}$ & $0.8 \mathrm{~mm}$ & $1.0 \mathrm{~mm}$ & $1.27 \mathrm{~mm}$ \\
\hline $\mathrm{SnPb}$ & 20 & 20 & 20 & 20 & 20 & 20 & 20 & 20 \\
\hline $\mathrm{SAC} 305-\mathrm{SnPb}$ & 20 & 20 & 20 & 20 & 20 & 20 & 20 & 20 \\
\hline $\mathrm{SAC} 105-\mathrm{SnPb}$ & 20 & 20 & 20 & 20 & 20 & 20 & 20 & 20 \\
\hline $\mathrm{SACX}-\mathrm{SnPb}$ & 20 & 20 & 20 & 20 & 20 & 20 & 20 & 20 \\
\hline SAC305 & 20 & 20 & 20 & 20 & 20 & 20 & 20 & 20 \\
\hline SAC105-SAC305 & 20 & 20 & 20 & 20 & 20 & 20 & 20 & 20 \\
\hline SACX-SAC305 & 20 & 20 & 20 & 20 & 20 & 20 & 20 & 20 \\
\hline SAC205-SAC305 & 20 & 20 & 20 & 20 & 20 & 20 & 20 & 20 \\
\hline
\end{tabular}


Where $\mu_{\mathrm{A} 1}$ is the population mean characteristic life for packages with ball/paste $\mathrm{SnPb}, \mu_{\mathrm{A} 2}$ is the population mean characteristic life for packages with ball/paste $\mathrm{SAC} 305-\mathrm{SnPb},[\ldots]$, and $\mu_{\mathrm{A} 8}$ is the population mean characteristic life for packages with ball/paste SnPbSAC205-SAC305.

\section{Factor B (Pitch)}

$\mathrm{H}_{0(\mathrm{~B})}: \mu_{\mathrm{B} 1}=\mu_{\mathrm{B} 2}=\mu_{\mathrm{B} 3}=\mu_{\mathrm{B} 4}$

$\mathrm{H}_{\mathrm{A}(\mathrm{B})}$ : at least one pair of the above is not equal

Where $\mu_{\mathrm{B} 1}$ is the population mean characteristic life for packages with pitch $0.50 \mathrm{~mm}, \mu_{\mathrm{B} 2}$ is the population mean characteristic life for packages with pitch $0.80 \mathrm{~mm}, \mu_{\mathrm{B} 3}$ is the population mean characteristic life for packages with pitch $1.00 \mathrm{~mm}, \mu_{\mathrm{B} 4}$ is the population mean characteristic life for packages with pitch $1.27 \mathrm{~mm}$.

The hypotheses for the remaining two-way ANOVAs also include ball/paste and pitch as factors. The remaining three response variables for these ANOVAs are the Weibull characteristic life $(\alpha)$ for the 0 to $100^{\circ} \mathrm{C}$ temperature cycling range, Weibull slope ( $(\beta)$ for the -40 to $125^{\circ} \mathrm{C}$ and 0 to $100{ }^{\circ} \mathrm{C}$ temperature cycling range. This results in a total of four sets of hypotheses (one for each response variable). 


\subsection{ANOVA Results}

The results of the ANOVA reveal whether package construction and ball/paste has a significant effect on the characteristic life and slope of the low-Ag BGA assembly ATC data for both temperature ranges. The differentiation of the temperature ranges is important because the $40^{\circ} \mathrm{C}$ to $125{ }^{\circ} \mathrm{C}$ temperature cycling range represents harsher thermal conditions from normal component use than the $0^{\circ} \mathrm{C}$ to $100{ }^{\circ} \mathrm{C}$ temperature cycling range. Determining whether ball/paste alloys and pitch sizes will have a statistically significant effect on Weibull characteristic life has the potential to be applied to BGA package and alloy selection. Similar Weibull slopes indicate the same failure mode, while Weibull slopes which are not similar can indicate multiple failure modes. Because the failure mode of interest is a crack from thermal fatigue, it is necessary see whether other failure modes may be present.

\subsubsection{ANOVA Results: Weibull Characteristic Life: $0^{\circ} \mathrm{C}$ to $100{ }^{\circ} \mathrm{C}$ TCR}

Characteristic life for both temperature cycling ranges was examined. For 0 to $100^{\circ} \mathrm{C}$ temperature cycling range, ball/paste and pitch were both significant factors with $p$-values of 0.001 and $<0.0001$, respectively, as shown in

Table 13. The LS Means plot for pitch in Figure 8 shows that the characteristic life for $0.8 \mathrm{~mm}$ pitch is the lowest. The Tukey's test of multiple comparisons shown in Table 14 indicates that the characteristic life for $0.8 \mathrm{~mm}$ pitch is statistically significantly different from that for $1.0 \mathrm{~mm}$ and $1.27 \mathrm{~mm}$ pitch. In addition, the characteristic life for $1.27 \mathrm{~mm}$ pitch is statistically significant longer than that for other pitches.

Table 13. ANOVA Table for Weibull characteristic life (0 to $100{ }^{\circ} \mathrm{C}$ )

\begin{tabular}{|c|c|c|c|c|}
\hline Source & DF & SS & F Ratio & p-value \\
\hline pitch & 3 & $130,231,567$ & 40.95 & $<.0001$ \\
\hline
\end{tabular}




\begin{tabular}{|l|l|l|l|l|} 
ball/paste & 7 & $41,265,630$ & 5.56 & 0.001 \\
\hline
\end{tabular}

Table 14. Tukey's multiple comparisons for Weibull characteristic life of different package constructions ( 0 to $100{ }^{\circ} \mathrm{C}$ )

\begin{tabular}{|c|c|c|c|c|}
\hline Pitch Level & \multicolumn{3}{|c|}{ Group } & $\begin{array}{c}\text { Least Sq Mean } \\
\text { (cycles) }\end{array}$ \\
\hline $1.27 \mathrm{~mm}$ & $\mathrm{~A}$ & & & 7471.99 \\
\hline $1.0 \mathrm{~mm}$ & & $\mathrm{~B}$ & & 4330.58 \\
\hline $0.5 \mathrm{~mm}$ & & $\mathrm{~B}$ & $\mathrm{C}$ & 3014.37 \\
\hline $0.8 \mathrm{~mm}$ & & & $\mathrm{C}$ & 2160.84 \\
\hline
\end{tabular}

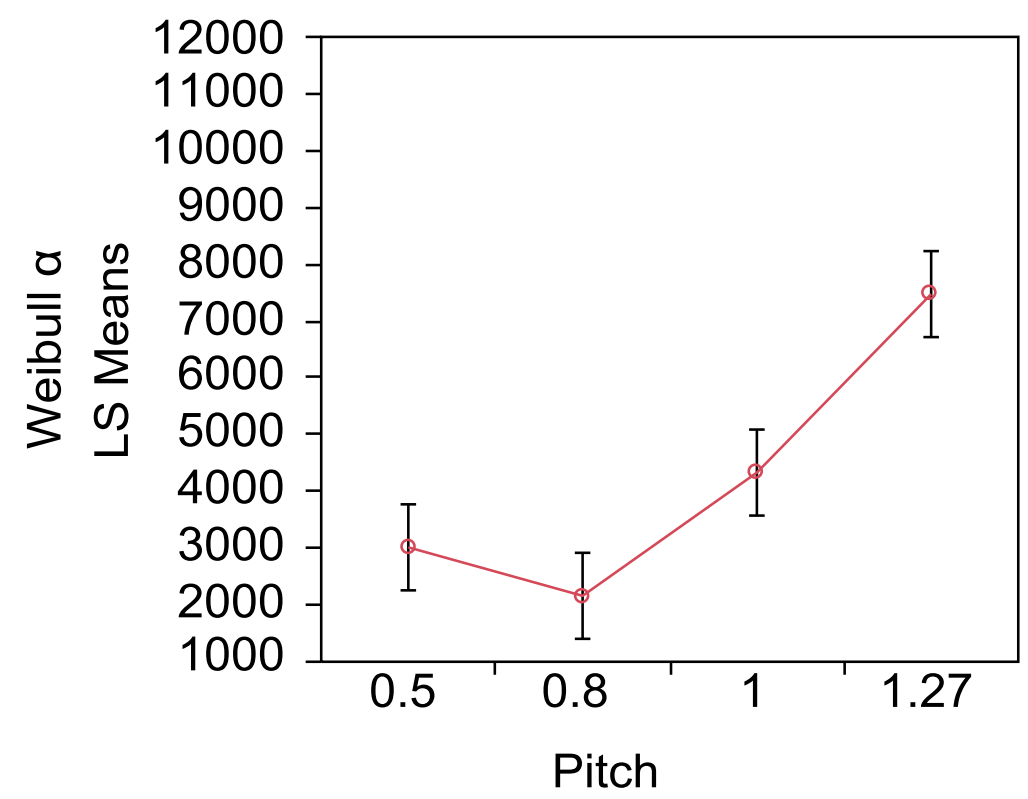

Figure 8. Weibull characteristic life LS Means for pitch $\left(0\right.$ to $\left.100{ }^{\circ} \mathrm{C}\right)$

The LS Means plot for ball/paste in Figure 9 shows that ball/paste has statistically significant effect on the characteristic life of solder joints. Table 15 shows the Tukey's multiple comparisons for Weibull characteristic life of different ball/paste (0 to $\left.100{ }^{\circ} \mathrm{C}\right)$. 


\subsubsection{ANOVA Results: Weibull Characteristic Life: $-40^{\circ} \mathrm{C}$ to $125^{\circ} \mathrm{C}$ TCR}

For the -40 to $125^{\circ} \mathrm{C}$ temperature cycling range, Table 16 shows that package construction or pitch was a significant factor for Weibull characteristic life while ball/paste was not. The LS means plot for pitch in Figure 6 shows a very similar result as the 0 to $100{ }^{\circ} \mathrm{C}$ temperature cycling range. Table 10 is the Tukey's multiple comparisons for Weibull characteristic life of different ball/paste $\left(-40\right.$ to $\left.125^{\circ} \mathrm{C}\right)$.

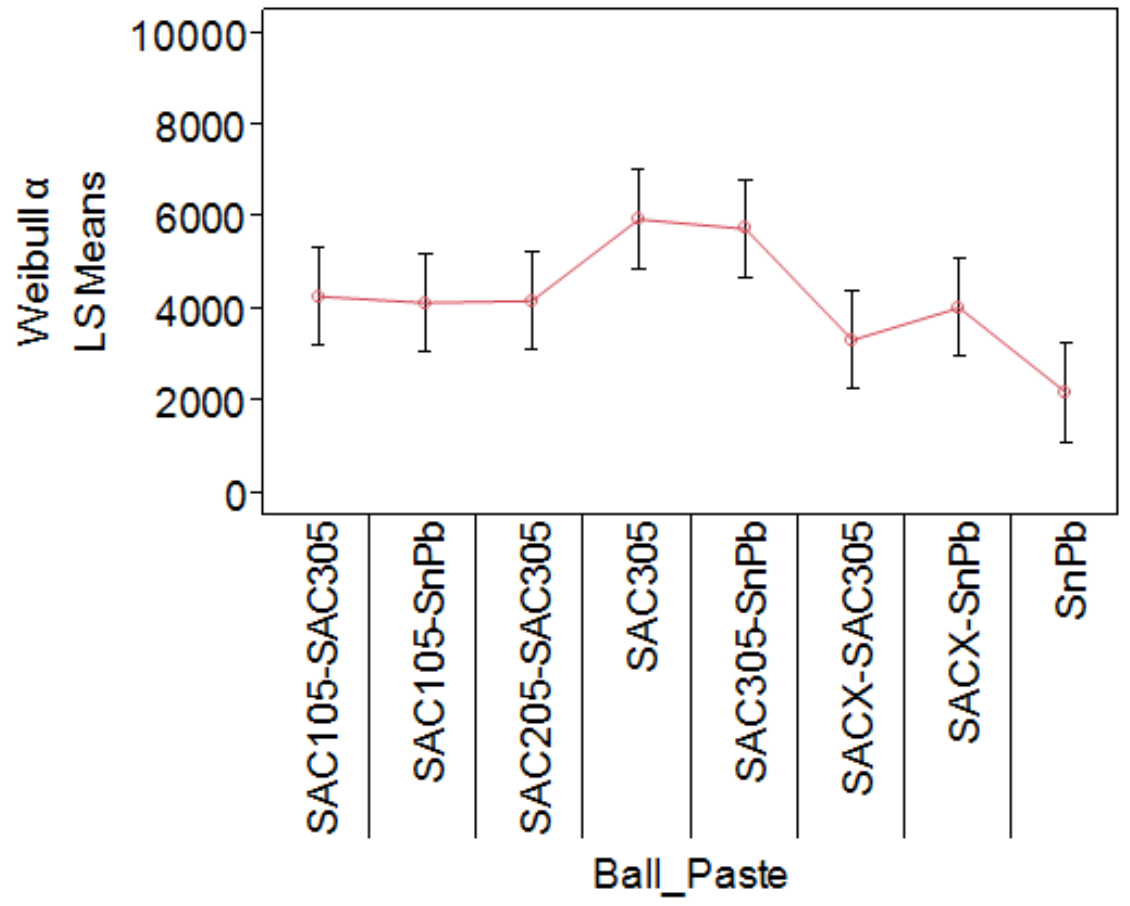

Figure 9. Weibull characteristic life LS Means for ball/paste $\left(0\right.$ to $\left.100{ }^{\circ} \mathrm{C}\right)$

Table 15. Tukey's Test for Weibull characteristic life $\alpha$ for different ball/paste $\left(0\right.$ to $\left.100{ }^{\circ} \mathrm{C}\right)$

\begin{tabular}{|c|c|c|c|c|}
\hline Level & \multicolumn{2}{|c|}{ Group } & Least Sq Mean (cycles) \\
\hline SAC305 & A & & & 5966.71 \\
\hline SAC305-SnPb & A & B & & 5761.52 \\
\hline SAC105-SAC305 & A & B & C & 4292.45 \\
\hline SAC205-SAC305 & A & B & C & 4194.04 \\
\hline SAC105-SnPb & A & B & C & 4153.49 \\
\hline SACX-SnPb & A & B & C & 4045.39 \\
\hline SACX-SAC305 & & B & C & 3342.73 \\
\hline SnPb & & & C & 2199.24 \\
\hline
\end{tabular}


Table 16. ANOVA Table for Weibull characteristic life $\alpha\left(-40\right.$ to $\left.125^{\circ} \mathrm{C}\right)$

\begin{tabular}{|l|l|l|l|l|}
\hline Source & DF & SS & F Ratio & p-value \\
\hline pitch $(\mathrm{mm})$ & 3 & 6773844 & 79.43 & $<.0001$ \\
\hline ball/paste & 7 & 193486 & 0.97 & 0.4762 \\
\hline
\end{tabular}

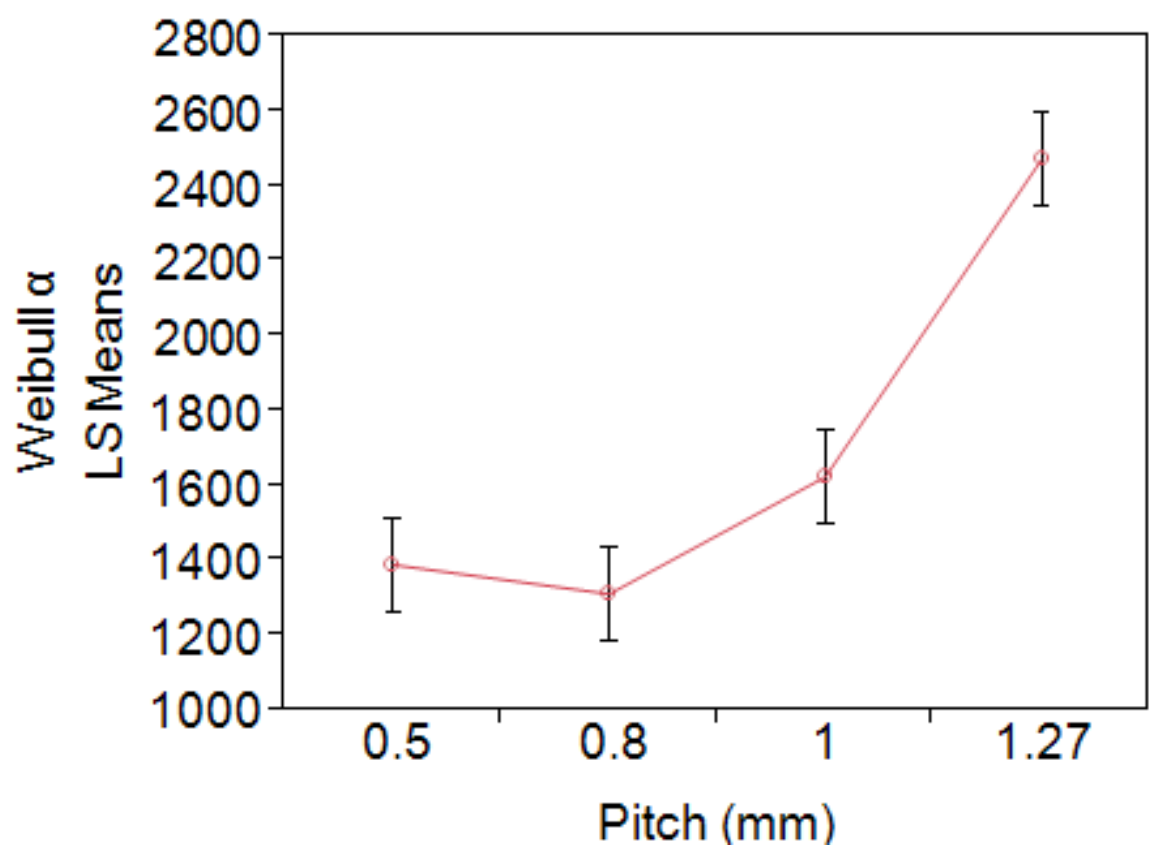

Figure 10. Weibull characteristic life LS Means for pitch $\left(-40\right.$ to $\left.125^{\circ} \mathrm{C}\right)$

Table 17. Tukey's Test for Weibull characteristic life for different package constructions (40 to $125^{\circ} \mathrm{C}$ )

\begin{tabular}{|c|c|c|c|c|}
\hline Pitch Level & \multicolumn{2}{|c|}{ Group } & Least Sq Mean (cycles) \\
\hline $1.27 \mathrm{~mm}$ & A & & & 2471.31 \\
\hline $1.0 \mathrm{~mm}$ & & B & & 1625.15 \\
\hline $0.5 \mathrm{~mm}$ & & B & C & 1390.23 \\
\hline $0.8 \mathrm{~mm}$ & & & C & 1312.39 \\
\hline
\end{tabular}

\subsubsection{ANOVA Results: Weibull Slope: $0^{\circ} \mathrm{C}$ to $100{ }^{\circ} \mathrm{C}$ TCR}

Table 18 shows that package construction or pitch has a statistically significant effect on the Weibull slope for the 0 to $100{ }^{\circ} \mathrm{C}$ temperature cycling range, while ball/paste does not have a significant effect. Tukey's test in Table 19 and the LS means plot in Figure 11. 
Weibull slope $\beta$ LS Means for pitch (0 to $100{ }^{\circ} \mathrm{C}$ ) shows that Weibull slope for package types with a $1.27 \mathrm{~mm}$ pitch is statistically significant lower than those with any other pitch size, which indicates that the failure mode of solder joints with a $1.27 \mathrm{~mm}$ pitch may be different from that packages with a $0.5 \mathrm{~mm}, 0.8 \mathrm{~mm}$, and $1.0 \mathrm{~mm}$ pitch.

Table 18. ANOVA Table for Weibull slope $\beta\left(0\right.$ to $\left.100{ }^{\circ} \mathrm{C}\right)$

\begin{tabular}{|c|c|c|c|c|}
\hline Source & DF & SS & $\begin{array}{c}\text { F } \\
\text { Ratio }\end{array}$ & $\begin{array}{c}\text { p- } \\
\text { value }\end{array}$ \\
\hline pitch & 3 & 100.76 & 9.31 & 0.0004 \\
\hline ball/paste & 7 & 35.26 & 1.49 & 0.2583 \\
\hline
\end{tabular}

Table 19. Weibull $\beta$ Tukey's Test for pitch $\left(0\right.$ to $\left.100{ }^{\circ} \mathrm{C}\right)$

\begin{tabular}{|c|c|c|c|}
\hline Pitch Level & \multicolumn{2}{|c|}{ Group } & Least Sq Mean \\
\hline $0.5 \mathrm{~mm}$ & A & & 8.07 \\
\hline $1.0 \mathrm{~mm}$ & A & & 7.26 \\
\hline $0.8 \mathrm{~mm}$ & A & & 6.86 \\
\hline $1.27 \mathrm{~mm}$ & & B & 3.43 \\
\hline
\end{tabular}

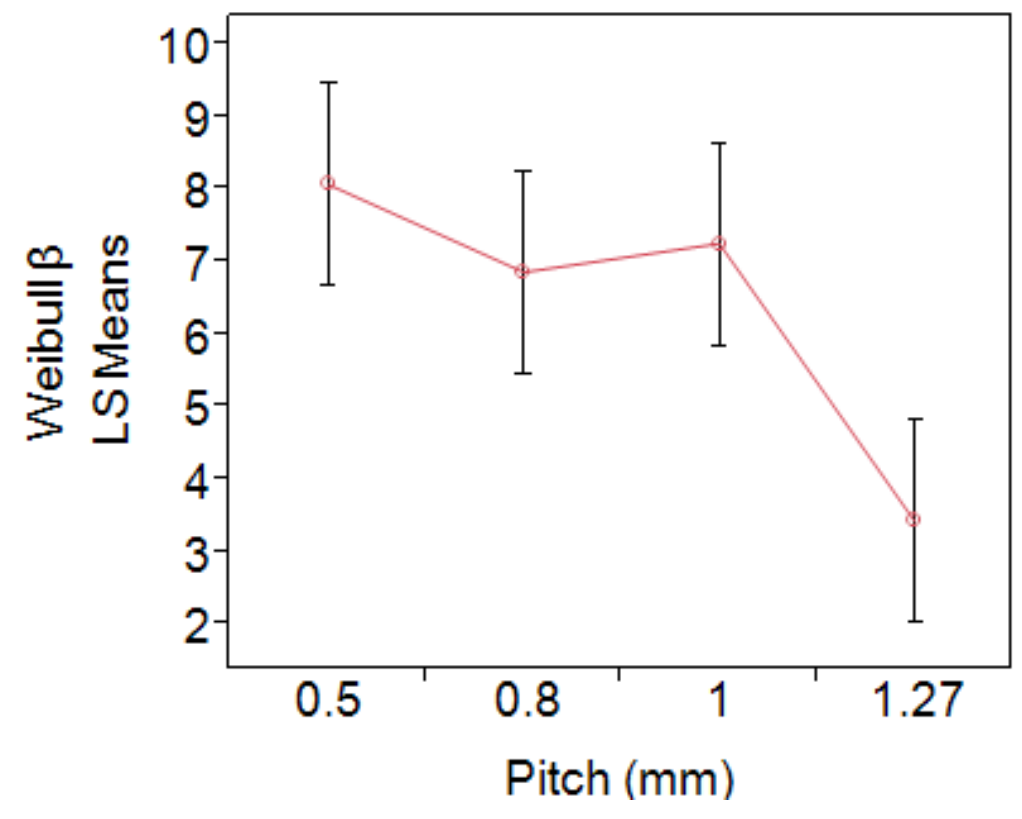

Figure 11. Weibull slope $\beta$ LS Means for pitch $\left(0\right.$ to $\left.100{ }^{\circ} \mathrm{C}\right)$

\subsubsection{ANOVA Results: Weibull Slope $-40^{\circ} \mathrm{C}$ to $125^{\circ} \mathrm{C}$ TCR}

For the -40 to $125^{\circ} \mathrm{C}$ temperature cycling range, the ANOVA shown in Table 20 shows that neither pitch nor ball/paste was significant factor for the Weibull slope. Because there is no difference in the Weibull slope due to the solder joint package type or alloy 
type, this implies that the failure mode for the solder joints is the same for the solder joints with the -40 to $125^{\circ} \mathrm{C}$ temperature cycling condition.

Table 20. ANOVA Table for Weibull characteristic life $\beta\left(-40\right.$ to $\left.125^{\circ} \mathrm{C}\right)$

\begin{tabular}{|c|c|c|c|c|}
\hline Source & DF & SS & F Ratio & p-value \\
\hline pitch & 3 & 3.52 & 1.63 & 0.2117 \\
\hline ball/paste & 7 & 7.26 & 1.44 & 0.2409 \\
\hline
\end{tabular}




\section{Chapter 6. Conclusions and Discussions}

Four failure criteria were compared in solder joint reliability life estimation. These failure criteria include a failure criterion based on $\bar{X}$ and $\mathrm{R}$ control charts, a $20 \%$ resistance increase defined in the IPC-9701A, $500 \Omega$ resistance threshold, and Infinite Resistance. Results show that $\bar{X}$ and $\mathrm{R}$ failure criterion has very similar cycles to failure as the IPC9701A failure criterion for both temperature cycling ranges. The $\bar{X}$ and $\mathrm{R}$ failure criterion detects failures marginally sooner than IPC-9701A. Both the $\bar{X}$ and R failure criterion and IPC-9701A detected failure earlier than $500 \Omega$ resistance threshold and Infinite Resistance failure criteria. In addition, when Infinite Resistance failure criterion is used, more failure data are right-censored compared to when other failure criteria are used.

The reliability of the solder joints was assessed using the $\bar{X}$ and $\mathrm{R}$ failure criterion. Pitch (package structure) had a statistically significant effect on Weibull characteristic life of low-silver BGA solder joints for data from both temperature cycling ranges, with $0.8 \mathrm{~mm}$ pitch packages having the lowest characteristic life.

Ball/paste (solder joint composition) had a statistically significant effect on Weibull characteristic life of low-silver BGA solder joints for 0 to $100^{\circ} \mathrm{C}$ thermal cycling data, but not for -40 to $125^{\circ} \mathrm{C}$ thermal cycling data. This indicates that there is no statistically significant difference in reliability life among ball/paste alloys for -40 to $125^{\circ} \mathrm{C}$ thermal cycling range data. 
Both pitch (package structure) and ball/paste (solder joint compositions) have no statistically significant effect on Weibull slope for both temperature ranges, with the exception of pitch for 0 to $100^{\circ} \mathrm{C}$ data. This indicates that the failure mode for all treatments may be the same.

\subsection{Package Construction and Weibull Characteristic Life Relationship}

A significant relationship between package construction and Weibull characteristic life is seen in both temperature ranges. Although it is known that finer pitch BGA assemblies result in fewer cycles-to-failure, the $0.8 \mathrm{~mm}$ pitch BGA joints showed the lowest Weibull

characteristic life for both temperature ranges. Although pitch varied for each BGA package studied, the BGA assemblies were not of the same package construction regardless of pitch. There are other factors which could have resulted in the lowest characteristic life for $0.8 \mathrm{~mm}$ pitch $\mathrm{BGA}$ assemblies, which are unknown. If the BGA assemblies had the same package construction of the BGA assemblies with the exception of pitch, there would have likely been an increase in characteristic life with an increase in ball pitch.

\subsection{Effect of Temperature Cycling Range on Weibull Characteristic Life}

As expected, the larger temperature cycling range resulted in a lower characteristic life for BGA packages thermally cycled at -40 to $125^{\circ} \mathrm{C}$ when compared to the packages subject to the 0 to $100^{\circ} \mathrm{C}$ temperature cycling range. The effect of ball/paste composition 
on Weibull characteristic life differed for the temperature cycling range. Ball/paste did not have a statistically significant effect on Weibull characteristic life for the -40 to $125^{\circ} \mathrm{C}$, which indicates that for BGA assemblies used for applications in which there are harsher thermal conditions, many alloys can be used without affecting the reliability life of the device. However, for less extreme conditions, which are represented at the 0 to $100^{\circ} \mathrm{C}$ temperature cycling range, solder alloy selection is important. In these cases, SAC305 would be a better solder alloy choice than $\mathrm{SnPb}$.

\subsection{Possible Further Work}

The results and conclusions from this study show the applicability of the $\bar{X}$ and $\mathrm{R}$ failure criterion to the low-silver BGA assembly ATC data. However, the $\bar{X}$ and $\mathrm{R}$ failure criterion has not been applied to any other failure data with the exception of the data from the initial proposal by Pan and Silk. It would be interesting to if the $\bar{X}$ and $\mathrm{R}$ failure criterion would yield similar results as the IPC-9701A failure criterion when applied to other types of accelerated tests.

Although the low-Ag BGA assembly study included accelerated thermal cycling, the drop-shock performance of the BGA assemblies was not evaluated in the study. Although the benefits of low-Ag alloys for drop shock performance has already been documented in previous, relationships between the other factors which were examined in the low-Ag BGA assembly study (peak reflow temperature, temperature cycling range, package construction, etc.) could have been evaluated in another design of experiment. 


\section{References}

[1] P. O'Connor, Practical Reliability Engineering, 3rd ed. New York: Wiley, 1991.

[2] H. Kim, M. Zhang, C.M. Kumar, D. Suh, P. Liu, D. Kim, M. Xie, and Z. Wang, "Improved drop reliability performance with lead free solders of low Ag content and their failure modes," Proceedings of IEEE Electronics Components and Technology Conference, 2007, pp. 962-967.

[3] R.S. Pandher, B.G. Lewis, R. Vangaveti, and B. Singh, "Drop shock reliability of lead-free alloys -- Effect of micro-additives," Proceedings of IEEE Electronics Components and Technology Conference, 2007, pp. 669-676.

[4] C. Birzer, B. Rakow, R. Steiner, and J. Walter, "Drop Test Reliability Improvement of Lead-free Fine Pitch BGA Using Different solder Ball Component," Proceedings of $7^{\text {th }}$ Electronics Packaging Technology Conference, Singapore, 2005, pp. 255-261.

[5] Y-S. Lai. P-F. Yang, and C-L. Yeh, "Experimental Studies of Board-level Reliability of Chip-scale Packages Subjected to JEDEC Drop Test Condition," Microelectronics Reliability, Vol. 46, No. 2-4, 2006, pp. 645-650.

[6] H. Qi, N.M. Vichare, M. H. Azarian, and M. Pecht, "Analysis of Solder Joint Failure Criteria and Measurement Techniques in the Qualification of Electronic Products," IEEE Transactions on Components and packaging Technologies, Vol. 31, No. 2, 2008, pp. 469-477. 
[7] J. Pan and J. Silk, "A Study of Solder Joint Failure Criteria," Proceedings of 44th International Symposium on Microelectronics, Long Beach, CA, 2011, pp. 694702.

[8] G. Henshall, C. Shea, R. Pandher, A. Syed, Q. Chu, N. Tokotch, L. Escuro, M. Lapitan, G. Ta, A. Babasa, G. Wable, "Low-Silver BGA Assembly, Phase I Reflow Considerations and Joint Homogeneity Reliability Assessment Initial Report," Proceedings of APEX, Las Vegas, NV, 2008.

[9] M. Abtew and G. Selvaduray, "Lead-Free Solders in Microelectronics," Material Science Engineering, Vol. 27, No. 5-6, 2000, pp. 95-141.

[10] H.L.J. Pang, T.H Low, B.S. Xiong and F.X. Che, "Design For Reliability (DFR) Methodology For Electronic Packaging Assemblies," Proceedings of 5th EPTC, December 10-12, Singapore, 2003, pp. 470-478.

[11] NIST/SEMATECH e-Handbook of Statistical Methods, http://www.itl.nist.gov/ div898/ handbook/.

[12] E. Suhir, "Accelerated life testing in microelectronics and photonics, its role, attributes, challenges, pitfalls and its interaction with qualification tests," Proceedings of the $2^{\text {nd }}$ International IEEE Conference on Polymers and Adhesives in Microelectronics and Photonics, Zalaegerszeg, 2002, pp. 44-48.

[13] K. Tunga, K. Kacker, R. V. Pucha, and S. K. Sitaraman, "Accelerated thermal cycling: Is it different for lead-free solder?" Proceedings of 54th ECTC Conference, 2004, pp. 1579-1585. 
[14] Y. Qi, R. Lam, R. H. Ghorbani, P. Snugovsky, and J. K. Spelt, "Temperature profile effects in accelerated thermal cycling of $\mathrm{SnPb}$ and $\mathrm{Pb}$-free solder joints," Microelectronics Reliability, Vol. 46, 2006, pp. 574-588.

[15] A. Mawer, D. Cho, and R. Darveaux, "The Effect of PBGA Solder Pad Geometry on Solder Joint Reliability,” Proceedings of SMI, 1996, pp. 127-135

[16] T. T. Mattila, H. Xu, O. Ratia, and M. Paulasto- Krackel, "Effects of thermal cycling parameters on lifetimes and failure mechanism of solder interconnections," Proceedings of the 60th Electronic Component and Technology Conference, 2010, pp. 581-590.

[17] R. Darveaus and K. Banerji, "Fatigue analysis of flip chip assemblies using thermal stress simulations and a coffin-mason relation," Proceedings of 41st Electronic Components and Technology Conference, 1991, pp. 797-805.

[18] X. W. Zhang and S. W. R. Lee, "Effects of temperature profile on the life prediction of PBGFA solder joints under thermal cycling," Key Engineering Materials, Vol. 145-149, 1998, pp. 1133-1138.

[19] A. Syed, "Reliability of Lead-Free Solder Connections for Area-Array Packages," Proceedings of IPC SMEMA Council APEX Conference, 2001.

[20] P. Rouhaud, G. Henshall, R. Bulwith, S. Prasad, F. Carson, S. Kamath, E. O'Keeffe, "Thermal Fatigue Resistance of Pb-Free Second Level Interconnect," Proceedings of 2001 SMTA International Conferences, 2001.

[21] A. Schubert, R. Dudek, R. Döring, H. Walter, E. Auerswald, A. Gollhardt, G. Schuch, H. Sitzmann, B. Michel., "Lead-free Solder Interconnects: 
Characterization, Testing and Reliability," Proceedings of $3^{\text {rd }}$ EuroSimE Conference, Paris, 2002, pp. 62-72.

[22] Meilunas, M., Primavera, A., Steven, O., Dunford., "Reliability and Failure Analysis of Lead-Free Solder Joints," Proceedings of IPC Annual Conference, New Orleans, 2001.

[23] Xie, D., Arra, M., Pan, H., Shangguan, D., Geiger, D., Yi, S., "Life Prediction of Lead Free Solder Joints for Handheld Products," Proceedings of 2002 IMAPBMTA Conference, 2002.

[24] A.R. Syed, "Thermal fatigue Reliability enhancement of plastic ball grid array (PBGA) packages," Proceedings of Electronic Components and Technology Conf., Orlando, FL, 1996, pp. 1211-1216.

[25] S. C. Bolton, A. J. Mawer, and E. Mammo, "Influence of Plastic Ball Grid Array Design Material Upon Solder Joint Reliability," The International Journal of Microcircuits and Electronic Packaging, Vol. 18, No. 2, 1995, pp109-121.

[26] T.I. Ejim, and A. Holliday, "Designed Experiment to Determine Attachment Reliability Drivers for PBGA Packages," Proceedings of Surface Mount International, 1995, pp. 385-392.

[27] Tanaka, M., Sasaki, T., Kobayashi, T., and Tatsumi, K., "Improvement in Drop Shock Reliability of Sn-i.2Ag-0.5Cu BGA Interconnects by Ni Addition," Proceedings of the 56th Electronic Component and Technology Conference, 2006, pp. 78-84. 
[28] S. Terashima and M. Tanaka, "Thermal fatigue properties of $\mathrm{Sn}-1.2 \mathrm{Ag}-0.5 \mathrm{Cu}-\mathrm{xNi}$ flip chip interconnects," Materials Transactions, Special Issue on Lead-Free Soldering in Electronics, Vol. 45, No. 3, 2004, pp. 681-688.

[29] Huang, M. L., Wang, L., "Effects of $\mathrm{Cu}, \mathrm{Bi}$ and In on Microstructure and Tensile Properties of SnAg-X (Cu, Bi, In) Solders," Metallurgical and Materials Transactions A, Vol. 36, No. 6, 2005, pp. 1439-1446.

[30] P.L. Liu and J. K. Shang, "Interfacial Segregation of Bismuth in Cu/Sn-Bi Solder Interconnect, Scripta Met. 44, 2001, pp. 1019-1023.

[31] J. Zhao, L. Qi, X. Wang, L. Wang, "Influence of Bi on microstructures evolution and mechanical properties in $\mathrm{Sn}-\mathrm{Ag}-\mathrm{Cu}$ lead-free solder," Journal of Alloys and Compounds, Vol. 375, 2004, pp. 196-201.

[32] W.W. Lee, L.T. Nguyen, G.S. Selvaduray, "Solder joint fatigue models: review and applicability to chip scale packages," Microelectronics Reliability, Vol. 40, No. 2, 2000, pp. 231-244.

[33] C. Montgomery, Introduction to Statistical Quality Control, $6^{\text {th }}$ ed., Wiley, 2009.

[34] G. Henshall, M. Fehrenbach, C. Shea, Q. Chu, G. Wable, R. Pandher, K. Hubbard, G. Ramakrishna, A. Syed, "Low-Silver BGA Assembly, Phase II - Reliability Assessment. Sixth Report: Thermal Cycling Results for Unmixed Joints," SMTA International Conference Proceedings, 2010.

[35] IPC-9701, "Performance Test Methods and Qualification Requirements for Surface Mount Solder Attachments," Association Connecting Electronics Industries, 2002. 
[36] G. Henshall, M. Fehrenbach, C. Shea, Q. Chu, G. Wable, R. Pandher, K. Hubbard, G. Ramakrishna, A. Syed, "Low-Silver BGA Assembly Phase II - Reliability Assessment Seventh Report: Mixed Metallurgy Solder Joint Thermal Cycling Results," Proceedings of IPC APEX, 2011.

[37] R. Kinyanjui, Q. Chu , P. Snugovsky , R. Coyle, "Solder Joint Reliability of PbFree Sn-Ag-Cu Ball grid Array (BGA) Components in Sn-Pb Assembly Process,” Proceedings of SMTA International, 2007. 


\section{Appendix A}

Cycles to failure for low-silver BGA data for each failure criteria

\begin{tabular}{|c|c|c|c|c|c|c|c|c|c|c|c|}
\hline \multicolumn{4}{|c|}{ Treatment } & \multicolumn{4}{|c|}{$0^{\circ} \mathrm{C}$ to $100^{\circ} \mathrm{C}$ TCR } & \multicolumn{4}{|c|}{$-40{ }^{\circ} \mathrm{C}$ to $125^{\circ} \mathrm{C}$ TCR } \\
\hline $\begin{array}{c}\text { Pkg } \\
\text { Desc } \\
(\mathrm{mm}) \\
\end{array}$ & $\begin{array}{l}\text { Paste } \\
\text { Alloy }\end{array}$ & $\begin{array}{l}\text { Ball } \\
\text { Alloy }\end{array}$ & $\begin{array}{l}\text { PRT } \\
\left({ }^{\circ} \mathrm{C}\right)\end{array}$ & $\underset{\text { and } R}{\overline{\mathbf{X}}}$ & $\begin{array}{l}\text { IPC- } \\
\text { 9701A }\end{array}$ & $500 \Omega$ & $\begin{array}{c}\text { Inf. } \\
\text { Resist. }\end{array}$ & $\underset{\text { and } R}{\bar{X}}$ & $\begin{array}{c}\text { IPC- } \\
\text { 9701A }\end{array}$ & $500 \Omega$ & $\begin{array}{c}\text { Inf. } \\
\text { Resist. }\end{array}$ \\
\hline 0.50 & SAC305 & SAC305 & 235 & 3793 & 3794 & 4095 & 4095 & 1253 & 1253 & 1310 & 1363 \\
\hline 0.50 & SAC305 & SAC305 & 235 & 3842 & 3842 & 4341 & 4341 & 1705 & 1705 & 1722 & 1722 \\
\hline 0.50 & SAC305 & SAC305 & 235 & 2881 & 2891 & 3459 & 3670 & 1943 & 1943 & 1945 & 1945 \\
\hline 0.50 & SAC305 & SAC305 & 235 & 3195 & 3195 & 3240 & 3240 & 1661 & 1661 & 1691 & 1691 \\
\hline 0.50 & SAC305 & SAC305 & 235 & 3441 & 3441 & 3766 & 3766 & 1637 & 1637 & 1643 & 1867 \\
\hline 0.50 & SAC305 & SAC305 & 235 & 3692 & 3697 & 4360 & 4360 & 1101 & 1101 & 1112 & 1112 \\
\hline 0.50 & SAC305 & SAC305 & 235 & 3540 & 3540 & 3748 & 3748 & 1334 & 1334 & 1355 & 1355 \\
\hline 0.50 & SAC305 & SAC305 & 235 & 3512 & 3512 & 3965 & 3965 & 1202 & 1202 & 1550 & 1550 \\
\hline 0.50 & SAC305 & SAC305 & 235 & 3182 & 3235 & 3468 & 3468 & 1828 & 1828 & 1837 & 1839 \\
\hline 0.50 & SAC305 & SAC305 & 235 & 3542 & 3542 & 3778 & 3779 & 1222 & 1222 & 1243 & 1603 \\
\hline 0.50 & SAC305 & SAC305 & 235 & 3647 & 3654 & 4084 & 4084 & 1651 & 1651 & 1660 & 1660 \\
\hline 0.50 & SAC305 & SAC305 & 235 & 3764 & 3764 & 3897 & 3897 & 1430 & 1429 & 1510 & 1510 \\
\hline 0.50 & SAC305 & SAC305 & 235 & 3558 & 3559 & 4094 & 4094 & 975 & 975 & 1082 & 1082 \\
\hline 0.50 & SAC305 & SAC305 & 235 & 3446 & 3446 & 3593 & 3593 & 1232 & 1232 & 1429 & 1471 \\
\hline 0.50 & SAC305 & SAC305 & 235 & 3466 & 3465 & 3918 & 3918 & 1222 & 1221 & 1309 & 1309 \\
\hline 0.50 & SAC305 & SAC305 & 235 & 3646 & 3647 & 4293 & 4293 & 1548 & 1548 & 1642 & 1642 \\
\hline 0.50 & SAC305 & SAC305 & 235 & 3915 & 3915 & 4188 & 4188 & 1417 & 1417 & 1676 & 1998 \\
\hline 0.50 & SAC305 & SAC305 & 235 & 2500 & 2500 & 2515 & 2515 & 1244 & 1244 & 1406 & 1406 \\
\hline 0.50 & SAC305 & SAC305 & 235 & 4433 & 4434 & 4975 & 4975 & 1461 & 1461 & 1467 & 1467 \\
\hline 0.50 & SAC305 & SAC305 & 235 & 2899 & 2900 & 3515 & 3515 & 1360 & 1360 & 1414 & 1587 \\
\hline 0.50 & SAC305 & SAC105 & 235 & 2905 & 2915 & 3609 & 3609 & 860 & 860 & 971 & 971 \\
\hline 0.50 & SAC305 & SAC105 & 235 & 3389 & 3392 & 3684 & 3684 & 1274 & 1274 & 1347 & 1347 \\
\hline 0.50 & SAC305 & SAC105 & 235 & 2701 & 2704 & 3587 & 3587 & 1240 & 1240 & 1373 & 1408 \\
\hline 0.50 & SAC305 & SAC105 & 235 & 3456 & 3456 & 3764 & 3764 & 1199 & 1199 & 1223 & 1223 \\
\hline 0.50 & SAC305 & SAC105 & 235 & 3172 & 3174 & 3402 & 3402 & 751 & 752 & 765 & 765 \\
\hline 0.50 & SAC305 & SAC105 & 235 & 3293 & 3299 & 3375 & 3375 & 818 & 837 & 864 & 1144 \\
\hline 0.50 & SAC305 & SAC105 & 235 & 2910 & 2911 & 2940 & 2940 & 742 & 742 & 752 & 1041 \\
\hline 0.50 & SAC305 & SAC105 & 235 & 2645 & 2648 & 2651 & 2651 & 1324 & 1324 & 1496 & 1496 \\
\hline 0.50 & SAC305 & SAC105 & 235 & 2448 & 2448 & 2501 & 2501 & 1276 & 1277 & 1331 & 1331 \\
\hline 0.50 & SAC305 & SAC105 & 235 & 2733 & 2733 & 2944 & 2944 & 844 & 843 & 848 & 848 \\
\hline 0.50 & SAC305 & SAC105 & 235 & 2673 & 2697 & 3063 & 3063 & 1266 & 1266 & 1273 & 1273 \\
\hline 0.50 & SAC305 & SAC105 & 235 & 2757 & 2757 & 2992 & 2992 & 930 & 930 & 940 & 940 \\
\hline
\end{tabular}




\begin{tabular}{|c|c|c|c|c|c|c|c|c|c|c|c|}
\hline \multicolumn{4}{|c|}{ Treatment } & \multicolumn{4}{|c|}{$0^{\circ} \mathrm{C}$ to $100^{\circ} \mathrm{C}$ TCR } & \multicolumn{4}{|c|}{$-40{ }^{\circ} \mathrm{C}$ to $125^{\circ} \mathrm{C}$ TCR } \\
\hline $\begin{array}{l}\text { Pkg } \\
\text { Desc } \\
(\mathrm{mm})\end{array}$ & $\begin{array}{l}\text { Paste } \\
\text { Alloy }\end{array}$ & $\begin{array}{l}\text { Ball } \\
\text { Alloy }\end{array}$ & $\begin{array}{l}\text { PRT } \\
\left({ }^{\circ} \mathbf{C}\right)\end{array}$ & $\begin{array}{c}\bar{X} \\
\text { and } R\end{array}$ & $\begin{array}{l}\text { IPC- } \\
\text { 9701A }\end{array}$ & $500 \Omega$ & $\begin{array}{l}\text { Inf. } \\
\text { Resist. }\end{array}$ & $\underset{\text { and } R}{\bar{X}}$ & $\begin{array}{l}\text { IPC- } \\
\text { 9701A }\end{array}$ & $500 \Omega$ & $\begin{array}{l}\text { Inf. } \\
\text { Resist. }\end{array}$ \\
\hline 0.50 & SAC305 & SAC105 & 235 & 3102 & 3102 & 3483 & 3483 & 1390 & 1390 & 1415 & 1420 \\
\hline 0.50 & SAC305 & SAC105 & 235 & 2216 & 2216 & 3140 & 3140 & 1017 & 1017 & 1048 & 1048 \\
\hline 0.50 & SAC305 & SAC105 & 235 & 3232 & 3232 & 3495 & 3495 & 1527 & 1527 & 1534 & 1534 \\
\hline 0.50 & SAC305 & SAC105 & 235 & 3170 & 3171 & 3797 & 3797 & 1534 & 1535 & 1602 & 1602 \\
\hline 0.50 & SAC305 & SAC105 & 235 & 2599 & 2599 & 2978 & 2978 & 1326 & 1326 & 1728 & 1728 \\
\hline 0.50 & SAC305 & SAC105 & 235 & 3512 & 3514 & 3911 & 4087 & 1036 & 1036 & 1046 & 1156 \\
\hline 0.50 & SAC305 & SAC105 & 235 & 3310 & 3310 & 3648 & 3648 & 1435 & 1435 & 1444 & 1446 \\
\hline 0.50 & SAC305 & SAC105 & 235 & 2770 & 2770 & 3033 & 3033 & 973 & 973 & 1055 & 1055 \\
\hline 0.50 & SAC305 & SACX & 235 & 3069 & 3070 & 3229 & 3229 & 1016 & 1016 & 1202 & 1357 \\
\hline 0.50 & SAC305 & SACX & 235 & 2267 & 2267 & 2545 & 2545 & 1566 & 1567 & 1603 & 1603 \\
\hline 0.50 & SAC305 & SACX & 235 & 2896 & 2899 & 2978 & 2978 & 1183 & 1183 & 1367 & 1367 \\
\hline 0.50 & SAC305 & SACX & 235 & 3384 & 3384 & 3602 & 3602 & 1368 & 1368 & 1410 & 1410 \\
\hline 0.50 & SAC305 & SACX & 235 & 2463 & 2463 & 3083 & 3083 & 1304 & 1307 & 1312 & 1314 \\
\hline 0.50 & SAC305 & SACX & 235 & 3752 & 3752 & 4033 & 4033 & 1187 & 1196 & 1216 & 1216 \\
\hline 0.50 & SAC305 & SACX & 235 & 2954 & 2968 & 3498 & 3498 & 1551 & 1551 & 1577 & 1593 \\
\hline 0.50 & SAC305 & SACX & 235 & 2572 & 2572 & 3142 & 3142 & 1568 & 1568 & 1577 & 1599 \\
\hline 0.50 & SAC305 & SACX & 235 & 2694 & 2694 & 2981 & 3263 & 1294 & 1295 & 1365 & 1451 \\
\hline 0.50 & SAC305 & SACX & 235 & 2398 & 2398 & 3033 & 3033 & 1247 & 1247 & 1261 & 1262 \\
\hline 0.50 & SAC305 & SACX & 235 & 3235 & 3235 & 3274 & 3592 & 1090 & 1090 & 1111 & 1111 \\
\hline 0.50 & SAC305 & SACX & 235 & 1811 & 1829 & 2830 & 3335 & 1059 & 1060 & 1060 & 1061 \\
\hline 0.50 & SAC305 & SACX & 235 & 2676 & 2677 & 2704 & 2704 & 1204 & 1204 & 1255 & 1273 \\
\hline 0.50 & SAC305 & SACX & 235 & 2820 & 2820 & 3679 & 3850 & 1282 & 1282 & 1283 & 1334 \\
\hline 0.50 & SAC305 & SACX & 235 & 2720 & 2721 & 2880 & 2880 & 1389 & 1389 & 1389 & 1389 \\
\hline 0.50 & SAC305 & SACX & 235 & 3332 & 3332 & 3458 & 3458 & 1534 & 1534 & 1627 & 1627 \\
\hline 0.50 & SAC305 & SACX & 235 & 2183 & 2201 & 2991 & 3023 & 846 & 846 & 1242 & 1311 \\
\hline 0.50 & SAC305 & SACX & 235 & 2626 & 2632 & 3224 & 3224 & 1117 & 1117 & 1344 & 1344 \\
\hline 0.50 & SAC305 & SACX & 235 & 2910 & 2910 & 3447 & 3447 & 1314 & 1314 & 1455 & 1471 \\
\hline 0.50 & SAC305 & SACX & 235 & 2981 & 2982 & 3277 & 3277 & 1219 & 1219 & 1271 & 1300 \\
\hline 0.50 & SAC305 & SAC205 & 235 & 2757 & 2757 & 2558 & 3190 & 1294 & 1294 & 1303 & 1303 \\
\hline 0.50 & SAC305 & SAC205 & 235 & 3393 & 3393 & 4093 & 4093 & 1301 & 1301 & 1328 & 1328 \\
\hline 0.50 & SAC305 & SAC205 & 235 & 2457 & 2458 & 3378 & 3378 & 1416 & 1416 & 1429 & 1448 \\
\hline 0.50 & SAC305 & SAC205 & 235 & 3919 & 3919 & 4391 & 4391 & 1411 & 1442 & 1471 & 1471 \\
\hline 0.50 & SAC305 & SAC205 & 235 & 3532 & 3532 & 4291 & 4291 & 1485 & 1485 & 1486 & 1488 \\
\hline 0.50 & SAC305 & SAC205 & 235 & 3578 & 3578 & 3580 & 4291 & 1051 & 1052 & 1077 & 1436 \\
\hline 0.50 & SAC305 & SAC205 & 235 & 2861 & 2861 & 3156 & 3156 & 1439 & 1439 & 1460 & 1461 \\
\hline 0.50 & SAC305 & SAC205 & 235 & 3398 & 3398 & 3798 & 3798 & 1415 & 1415 & 1420 & 1420 \\
\hline
\end{tabular}




\begin{tabular}{|c|c|c|c|c|c|c|c|c|c|c|c|}
\hline \multicolumn{4}{|c|}{ Treatment } & \multicolumn{4}{|c|}{$0^{\circ} \mathrm{C}$ to $100{ }^{\circ} \mathrm{C}$ TCR } & \multicolumn{4}{|c|}{$-40{ }^{\circ} \mathrm{C}$ to $125^{\circ} \mathrm{C}$ TCR } \\
\hline $\begin{array}{l}\text { Pkg } \\
\text { Desc } \\
(\mathrm{mm})\end{array}$ & $\begin{array}{l}\text { Paste } \\
\text { Alloy }\end{array}$ & $\begin{array}{c}\text { Ball } \\
\text { Alloy }\end{array}$ & $\begin{array}{l}\text { PRT } \\
\left({ }^{\circ} \mathbf{C}\right)\end{array}$ & $\underset{\text { and } R}{\overline{\mathbf{X}}}$ & $\begin{array}{l}\text { IPC- } \\
\text { 9701A }\end{array}$ & $500 \Omega$ & $\begin{array}{l}\text { Inf. } \\
\text { Resist. }\end{array}$ & $\underset{\text { and } R}{\overline{\mathbf{X}}}$ & $\begin{array}{l}\text { IPC- } \\
9701 \mathrm{~A}\end{array}$ & $500 \Omega$ & $\begin{array}{c}\text { Inf. } \\
\text { Resist. }\end{array}$ \\
\hline 0.50 & SAC305 & SAC205 & 235 & 3165 & 3165 & 3319 & 3319 & 1507 & 1507 & 1526 & 1526 \\
\hline 0.50 & SAC305 & SAC205 & 235 & 3791 & 3793 & 4130 & 4130 & 1273 & 1273 & 1290 & 1290 \\
\hline 0.50 & SAC305 & SAC205 & 235 & 3367 & 3368 & 4422 & 4422 & 1461 & 1462 & 1551 & 1575 \\
\hline 0.50 & SAC305 & SAC205 & 235 & 3281 & 3289 & 3495 & 3495 & 967 & 967 & 1030 & 1030 \\
\hline 0.50 & SAC305 & SAC205 & 235 & 3437 & 3438 & 3759 & 3759 & 1236 & 1236 & 1251 & 1251 \\
\hline 0.50 & SAC305 & SAC205 & 235 & 3336 & 3342 & 3866 & 3866 & 1060 & 1060 & 1095 & 1158 \\
\hline 0.50 & SAC305 & SAC205 & 235 & 3107 & 3108 & 3369 & 3369 & 1260 & 1260 & 1520 & 1520 \\
\hline 0.50 & SAC305 & SAC205 & 235 & 3309 & 3309 & 3965 & 3965 & 1677 & 1676 & 1712 & 1752 \\
\hline 0.50 & SAC305 & SAC205 & 235 & 3200 & 3200 & 3980 & 4059 & 1295 & 1295 & 1381 & 1381 \\
\hline 0.50 & SAC305 & SAC205 & 235 & 3224 & 3225 & 4061 & 4061 & 1361 & 1361 & 1366 & 1366 \\
\hline 0.50 & SAC305 & SAC205 & 235 & 2864 & 2865 & 3175 & 3175 & 1617 & 1617 & 1638 & 1680 \\
\hline 0.50 & SAC305 & SAC205 & 235 & 2869 & 2869 & 3454 & 3454 & 1481 & 1481 & 1500 & 1501 \\
\hline 0.50 & SAC305 & LF35 & 235 & 2811 & 2811 & 3000 & 3000 & 1555 & 1555 & 1555 & 1555 \\
\hline 0.50 & SAC305 & LF35 & 235 & 3375 & 3376 & 3906 & 3960 & 1409 & 1409 & 1452 & 1452 \\
\hline 0.50 & SAC305 & LF35 & 235 & 3457 & 3457 & 4030 & 4083 & 1447 & 1447 & 1453 & 1455 \\
\hline 0.50 & SAC305 & LF35 & 235 & 3020 & 3020 & 3788 & 3788 & 1353 & 1353 & 1353 & 1353 \\
\hline 0.50 & SAC305 & LF35 & 235 & 3194 & 3194 & 3533 & 3533 & 1168 & 1168 & 1177 & 1177 \\
\hline 0.50 & SAC305 & LF35 & 235 & 2834 & 2834 & 2733 & 2733 & 1077 & 1078 & 1104 & 1478 \\
\hline 0.50 & SAC305 & LF35 & 235 & 3482 & 3482 & 3634 & 3674 & 1748 & 1748 & 1749 & 1755 \\
\hline 0.50 & SAC305 & LF35 & 235 & 3229 & 3229 & 3695 & 3695 & 1677 & 1678 & 1681 & 1736 \\
\hline 0.50 & SAC305 & LF35 & 235 & 3069 & 3071 & 3685 & 3685 & 1709 & 1709 & 1726 & 1969 \\
\hline 0.50 & SAC305 & LF35 & 235 & 3237 & 3238 & 3742 & 3759 & 1420 & 1421 & 1428 & 1428 \\
\hline 0.50 & SAC305 & LF35 & 235 & 2819 & 2835 & 3073 & 3073 & 1402 & 1402 & 1427 & 1427 \\
\hline 0.50 & SAC305 & LF35 & 235 & 3200 & 3200 & 3771 & 3771 & 1288 & 1288 & 1336 & 1362 \\
\hline 0.50 & SAC305 & LF35 & 235 & 3259 & 3259 & 3500 & 3500 & 1455 & 1455 & 1468 & 1514 \\
\hline 0.50 & SAC305 & LF35 & 235 & 3931 & 3932 & 4042 & 4067 & 1028 & 1029 & 1032 & 1427 \\
\hline 0.50 & SAC305 & LF35 & 235 & 3205 & 3205 & 3354 & 3406 & 1386 & 1386 & 1389 & 1389 \\
\hline 0.50 & SAC305 & LF35 & 235 & 2948 & 2948 & 3557 & 3557 & 1167 & 1167 & 1183 & 1183 \\
\hline 0.50 & SAC305 & LF35 & 235 & 3331 & 3331 & 3473 & 3473 & 1352 & 1352 & 1370 & 1566 \\
\hline 0.50 & SAC305 & LF35 & 235 & 2669 & 2669 & 2779 & 2779 & 1376 & 1376 & 1378 & 1378 \\
\hline 0.50 & SAC305 & LF35 & 235 & 3334 & 3360 & 3507 & 3717 & 1595 & 1595 & 1599 & 1603 \\
\hline 0.50 & SAC305 & LF35 & 235 & 3009 & 3009 & 3654 & 3777 & 1375 & 1375 & 1536 & 1610 \\
\hline 0.80 & SAC305 & SAC305 & 235 & 3328 & 3328 & 3778 & 3778 & 664 & 667 & 780 & 1564 \\
\hline 0.80 & SAC305 & SAC305 & 235 & 2837 & 2838 & 3089 & 3364 & 1133 & 1133 & 1146 & 1389 \\
\hline 0.80 & SAC305 & SAC305 & 235 & 3127 & 3128 & 3662 & 4138 & 1697 & 1697 & 1789 & 1789 \\
\hline 0.80 & SAC305 & SAC305 & 235 & 3746 & 3746 & 3753 & 4387 & 927 & 927 & 960 & 1691 \\
\hline
\end{tabular}




\begin{tabular}{|c|c|c|c|c|c|c|c|c|c|c|c|}
\hline \multicolumn{4}{|c|}{ Treatment } & \multicolumn{4}{|c|}{$0^{\circ} \mathrm{C}$ to $100{ }^{\circ} \mathrm{C}$ TCR } & \multicolumn{4}{|c|}{$-40^{\circ} \mathrm{C}$ to $125^{\circ} \mathrm{C}$ TCR } \\
\hline $\begin{array}{c}\text { Pkg } \\
\text { Desc } \\
(\mathrm{mm})\end{array}$ & $\begin{array}{l}\text { Paste } \\
\text { Alloy }\end{array}$ & $\begin{array}{c}\text { Ball } \\
\text { Alloy }\end{array}$ & $\begin{array}{l}\text { PRT } \\
\left({ }^{\circ} \mathrm{C}\right)\end{array}$ & $\underset{\text { and } R}{\overline{\mathbf{X}}}$ & $\begin{array}{l}\text { IPC- } \\
\text { 9701A }\end{array}$ & $500 \Omega$ & $\begin{array}{l}\text { Inf. } \\
\text { Resist. }\end{array}$ & $\underset{\text { and } R}{\overline{\mathbf{X}}}$ & $\begin{array}{l}\text { IPC- } \\
\text { 9701A }\end{array}$ & $500 \Omega$ & $\begin{array}{l}\text { Inf. } \\
\text { Resist. }\end{array}$ \\
\hline 0.80 & SAC305 & SAC305 & 235 & 3717 & 3718 & 3918 & 4110 & 1137 & 1137 & 1141 & 1533 \\
\hline 0.80 & SAC305 & SAC305 & 235 & 4430 & 4430 & 4590 & 4954 & 1531 & 1531 & 1579 & 1881 \\
\hline 0.80 & SAC305 & SAC305 & 235 & 2456 & 2458 & 3273 & 3717 & 1255 & 1255 & 1298 & 1590 \\
\hline 0.80 & SAC305 & SAC305 & 235 & 1698 & 1698 & 2109 & 2905 & 999 & 999 & 1048 & 1692 \\
\hline 0.80 & SAC305 & SAC305 & 235 & 3114 & 3114 & 3445 & 3445 & 1530 & 1530 & 1647 & 1647 \\
\hline 0.80 & SAC305 & SAC305 & 235 & 2385 & 2385 & 2590 & 3782 & 1278 & 1278 & 1355 & 1364 \\
\hline 0.80 & SAC305 & SAC305 & 235 & 2766 & 2776 & 2846 & 3556 & 985 & 985 & 1257 & 1587 \\
\hline 0.80 & SAC305 & SAC305 & 235 & 3128 & 3128 & 3532 & 4025 & 1809 & 1807 & 1818 & 1818 \\
\hline 0.80 & SAC305 & SAC305 & 235 & 2804 & 2804 & 3540 & 3540 & 1356 & 1356 & 1366 & 1504 \\
\hline 0.80 & SAC305 & SAC305 & 235 & 3593 & 3593 & 4115 & 4316 & 1291 & 1290 & 1348 & 1403 \\
\hline 0.80 & SAC305 & SAC305 & 235 & 3086 & 3086 & 3486 & 3722 & 1398 & 1398 & 1588 & 1778 \\
\hline 0.80 & SAC305 & SAC305 & 235 & 2869 & 2869 & 3347 & 3428 & 1499 & 1499 & 1699 & 1699 \\
\hline 0.80 & SAC305 & SAC 305 & 235 & 2927 & 2927 & 3748 & 3748 & 1440 & 1439 & 1765 & 1765 \\
\hline 0.80 & SAC305 & SAC 305 & 235 & 2962 & 2962 & 2998 & 3285 & 1370 & 1370 & 1404 & 1404 \\
\hline 0.80 & SAC305 & SAC305 & 235 & 2783 & 2783 & 3474 & 3739 & 785 & 784 & 885 & 1528 \\
\hline 0.80 & SAC305 & SAC305 & 235 & 3852 & 3852 & 3938 & 4268 & 1716 & 1716 & 1779 & 1805 \\
\hline 0.80 & SAC305 & SAC105 & 235 & 2101 & 2101 & 2158 & 2158 & 708 & 708 & 720 & 720 \\
\hline 0.80 & SAC305 & SAC105 & 235 & 1921 & 1921 & 2058 & 2058 & 736 & 736 & 753 & 753 \\
\hline 0.80 & SAC305 & SAC105 & 235 & 2206 & 2207 & 2660 & 2684 & 831 & 831 & 841 & 841 \\
\hline 0.80 & SAC305 & SAC105 & 235 & 2178 & 2178 & 2417 & 2417 & 589 & 589 & 591 & 591 \\
\hline 0.80 & SAC305 & SAC105 & 235 & 1324 & 1324 & 1853 & 1853 & 1416 & 1416 & 1428 & 1428 \\
\hline 0.80 & SAC305 & SAC105 & 235 & 2603 & 2603 & 3024 & 3034 & 775 & 775 & 782 & 782 \\
\hline 0.80 & SAC305 & SAC105 & 235 & 1997 & 1997 & 2060 & 2060 & 585 & 585 & 637 & 757 \\
\hline 0.80 & SAC305 & SAC105 & 235 & 1686 & 1686 & 1777 & 1777 & 619 & 618 & 709 & 709 \\
\hline 0.80 & SAC305 & SAC105 & 235 & 1742 & 1742 & 2123 & 2123 & 792 & 792 & 794 & 794 \\
\hline 0.80 & SAC305 & SAC105 & 235 & 1974 & 1974 & 2271 & 2271 & 668 & 668 & 677 & 677 \\
\hline 0.80 & SAC305 & SAC105 & 235 & 1439 & 1439 & 1564 & 1564 & 679 & 679 & 682 & 682 \\
\hline 0.80 & SAC305 & SAC105 & 235 & 2050 & 2050 & 2094 & 2094 & 673 & 673 & 724 & 724 \\
\hline 0.80 & SAC305 & SAC105 & 235 & 1528 & 1528 & 1886 & 1886 & 689 & 689 & 740 & 748 \\
\hline 0.80 & SAC305 & SAC105 & 235 & 2285 & 2285 & 2619 & 2619 & 673 & 673 & 697 & 697 \\
\hline 0.80 & SAC305 & SAC105 & 235 & 1933 & 1933 & 2312 & 2312 & 661 & 661 & 688 & 688 \\
\hline 0.80 & SAC305 & SAC105 & 235 & 1928 & 1928 & 2457 & 2457 & 812 & 812 & 966 & 966 \\
\hline 0.80 & SAC305 & SAC105 & 235 & 2247 & 2247 & 2340 & 2340 & 816 & 816 & 937 & 937 \\
\hline 0.80 & SAC305 & SAC105 & 235 & 1866 & 1866 & 1969 & 2005 & 671 & 671 & 682 & 682 \\
\hline 0.80 & SAC305 & SAC105 & 235 & 1987 & 1987 & 2010 & 2010 & 631 & 631 & 635 & 635 \\
\hline 0.80 & SAC305 & SAC105 & 235 & 1897 & 1897 & 2292 & 2292 & 702 & 702 & 729 & 729 \\
\hline
\end{tabular}




\begin{tabular}{|c|c|c|c|c|c|c|c|c|c|c|c|}
\hline \multicolumn{4}{|c|}{ Treatment } & \multicolumn{4}{|c|}{$0^{\circ} \mathrm{C}$ to $100^{\circ} \mathrm{C}$ TCR } & \multicolumn{4}{|c|}{$-40{ }^{\circ} \mathrm{C}$ to $125^{\circ} \mathrm{C}$ TCR } \\
\hline $\begin{array}{l}\text { Pkg } \\
\text { Desc } \\
(\mathrm{mm})\end{array}$ & $\begin{array}{l}\text { Paste } \\
\text { Alloy }\end{array}$ & $\begin{array}{c}\text { Ball } \\
\text { Alloy }\end{array}$ & $\begin{array}{l}\text { PRT } \\
\left({ }^{\circ} \mathbf{C}\right)\end{array}$ & $\underset{\text { and } R}{\overline{\mathbf{X}}}$ & $\begin{array}{l}\text { IPC- } \\
\text { 9701A }\end{array}$ & $500 \Omega$ & $\begin{array}{c}\text { Inf. } \\
\text { Resist. }\end{array}$ & $\underset{\text { and } R}{\overline{\mathbf{X}}}$ & $\begin{array}{c}\text { IPC- } \\
\text { 9701A }\end{array}$ & $500 \Omega$ & $\begin{array}{c}\text { Inf. } \\
\text { Resist. }\end{array}$ \\
\hline 0.80 & SAC305 & SACX & 235 & 1726 & 1726 & 1776 & 1776 & 735 & 734 & 779 & 779 \\
\hline 0.80 & SAC305 & SACX & 235 & 1785 & 1785 & 1914 & 1914 & 863 & 863 & 881 & 887 \\
\hline 0.80 & SAC305 & SACX & 235 & 1852 & 1852 & 2035 & 2035 & 833 & 833 & 838 & 838 \\
\hline 0.80 & SAC305 & SACX & 235 & 2482 & 2482 & 2577 & 2577 & 675 & 675 & 679 & 679 \\
\hline 0.80 & SAC305 & SACX & 235 & 1882 & 1882 & 1923 & 1923 & 783 & 783 & 784 & 784 \\
\hline 0.80 & SAC305 & SACX & 235 & 2202 & 2202 & 2679 & 2679 & 788 & 787 & 809 & 809 \\
\hline 0.80 & SAC305 & SACX & 235 & 2263 & 2263 & 2506 & 2506 & 603 & 603 & 824 & 824 \\
\hline 0.80 & SAC305 & SACX & 235 & 2024 & 2024 & 2311 & 2311 & 697 & 697 & 706 & 706 \\
\hline 0.80 & SAC305 & SACX & 235 & 1887 & 1887 & 2264 & 2264 & 934 & 934 & 975 & 1049 \\
\hline 0.80 & SAC305 & SACX & 235 & 1781 & 1781 & 2168 & 2205 & 720 & 720 & 729 & 729 \\
\hline 0.80 & SAC305 & SACX & 235 & 1968 & 1968 & 2024 & 2024 & 629 & 629 & 701 & 701 \\
\hline 0.80 & SAC305 & SACX & 235 & 1799 & 1799 & 2080 & 2080 & 849 & 858 & 944 & 945 \\
\hline 0.80 & SAC305 & SACX & 235 & 1680 & 1682 & 2124 & 2124 & 586 & 586 & 590 & 591 \\
\hline 0.80 & SAC305 & SACX & 235 & 2499 & 2499 & 2695 & 2695 & 710 & 710 & 732 & 732 \\
\hline 0.80 & SAC305 & SACX & 235 & 1978 & 1979 & 2312 & 2312 & 833 & 833 & 948 & 948 \\
\hline 0.80 & SAC305 & SACX & 235 & 2020 & 2020 & 2143 & 2143 & 884 & 884 & 898 & 901 \\
\hline 0.80 & SAC305 & SACX & 235 & 2215 & 2216 & 2541 & 2541 & 950 & 950 & 1023 & 1077 \\
\hline 0.80 & SAC305 & SACX & 235 & 1812 & 1812 & 2072 & 2072 & 602 & 602 & 608 & 613 \\
\hline 0.80 & SAC305 & SACX & 235 & 1695 & 1696 & 2180 & 2180 & 644 & 644 & 653 & 653 \\
\hline 0.80 & SAC305 & SACX & 235 & 2018 & 2018 & 2297 & 2297 & 866 & 865 & 885 & 885 \\
\hline 0.80 & SAC305 & SAC205 & 235 & 2464 & 2464 & 4196 & 2979 & 663 & 662 & 718 & 718 \\
\hline 0.80 & SAC305 & SAC205 & 235 & 2243 & 2245 & 2709 & 2717 & 679 & 679 & 716 & 716 \\
\hline 0.80 & SAC305 & SAC205 & 235 & 2677 & 2677 & 3017 & 3181 & 858 & 858 & 897 & 930 \\
\hline 0.80 & SAC305 & SAC205 & 235 & 1850 & 1850 & 3327 & 3327 & 769 & 769 & 770 & 803 \\
\hline 0.80 & SAC305 & SAC205 & 235 & 2520 & 2520 & 2684 & 4423 & 874 & 874 & 880 & 904 \\
\hline 0.80 & SAC305 & SAC205 & 235 & 1992 & 1992 & 2002 & 2098 & 689 & 689 & 702 & 702 \\
\hline 0.80 & SAC305 & SAC205 & 235 & 2486 & 2486 & 2593 & 2593 & 752 & 752 & 817 & 817 \\
\hline 0.80 & SAC305 & SAC205 & 235 & 2129 & 2130 & 2525 & 2582 & 913 & 913 & 948 & 966 \\
\hline 0.80 & SAC305 & SAC205 & 235 & 2416 & 2416 & 2622 & 2622 & 1028 & 1028 & 1065 & 1066 \\
\hline 0.80 & SAC305 & SAC205 & 235 & 2886 & 2886 & 2988 & 2988 & 674 & 764 & 829 & 840 \\
\hline 0.80 & SAC305 & SAC205 & 235 & 2106 & 2106 & 2189 & 2565 & 883 & 883 & 885 & 892 \\
\hline 0.80 & SAC305 & SAC205 & 235 & 2511 & 2511 & 3097 & 3166 & 956 & 956 & 971 & 1162 \\
\hline 0.80 & SAC305 & SAC205 & 235 & 2873 & 2875 & 3175 & 3175 & 680 & 680 & 695 & 695 \\
\hline 0.80 & SAC305 & SAC205 & 235 & 2971 & 2971 & 3429 & 3429 & 830 & 830 & 869 & 869 \\
\hline 0.80 & SAC305 & SAC205 & 235 & 2214 & 2215 & 2451 & 2451 & 807 & 807 & 862 & 862 \\
\hline 0.80 & SAC305 & SAC205 & 235 & 2760 & 2761 & 2984 & 2984 & 852 & 852 & 892 & 915 \\
\hline
\end{tabular}




\begin{tabular}{|c|c|c|c|c|c|c|c|c|c|c|c|}
\hline \multicolumn{4}{|c|}{ Treatment } & \multicolumn{4}{|c|}{$0^{\circ} \mathrm{C}$ to $100{ }^{\circ} \mathrm{C}$ TCR } & \multicolumn{4}{|c|}{$-40{ }^{\circ} \mathrm{C}$ to $125^{\circ} \mathrm{C}$ TCR } \\
\hline $\begin{array}{l}\text { Pkg } \\
\text { Desc } \\
(\mathrm{mm})\end{array}$ & $\begin{array}{l}\text { Paste } \\
\text { Alloy }\end{array}$ & $\begin{array}{c}\text { Ball } \\
\text { Alloy }\end{array}$ & $\begin{array}{l}\text { PRT } \\
\left({ }^{\circ} \mathbf{C}\right)\end{array}$ & $\underset{\text { and } R}{\overline{\mathbf{X}}}$ & $\begin{array}{l}\text { IPC- } \\
\text { 9701A }\end{array}$ & $500 \Omega$ & $\begin{array}{l}\text { Inf. } \\
\text { Resist. }\end{array}$ & $\underset{\text { and } R}{\overline{\mathbf{X}}}$ & $\begin{array}{c}\text { IPC- } \\
\text { 9701A }\end{array}$ & $500 \Omega$ & $\begin{array}{c}\text { Inf. } \\
\text { Resist. }\end{array}$ \\
\hline 0.80 & SAC305 & SAC205 & 235 & 2591 & 2591 & 3230 & 3230 & 715 & 714 & 733 & 733 \\
\hline 0.80 & SAC305 & SAC205 & 235 & 2551 & 2554 & 2651 & 2954 & 601 & 600 & 668 & 676 \\
\hline 0.80 & SAC305 & SAC205 & 235 & 2185 & 2186 & 2958 & 2958 & 750 & 750 & 754 & 779 \\
\hline 0.80 & SAC305 & SAC205 & 235 & 2599 & 2599 & 3394 & 3394 & 769 & 767 & 789 & 793 \\
\hline 1.00 & SAC305 & SAC305 & 235 & 6030 & 6031 & 6371 & 6708 & 1967 & 1967 & 1972 & 2008 \\
\hline 1.00 & SAC305 & SAC305 & 235 & 6288 & 6288 & 6323 & 7080 & 2182 & 2182 & 2191 & 2348 \\
\hline 1.00 & SAC305 & SAC305 & 235 & 6323 & 6325 & 6386 & 6885 & 2084 & 2085 & 2086 & 2136 \\
\hline 1.00 & SAC305 & SAC305 & 235 & 6684 & 6684 & 6738 & 7493 & 2034 & 2034 & 2035 & 2117 \\
\hline 1.00 & SAC305 & SAC305 & 235 & 5447 & 5452 & 5902 & 7340 & 1497 & 1497 & 1516 & 1781 \\
\hline 1.00 & SAC305 & SAC305 & 235 & 5792 & 5795 & 6366 & 7284 & 2093 & 2093 & 2097 & 2232 \\
\hline 1.00 & SAC305 & SAC305 & 235 & 5494 & 5494 & 5579 & 5757 & 2021 & 2021 & 2077 & 2235 \\
\hline 1.00 & SAC305 & SAC305 & 235 & 4557 & 4557 & 4661 & 5173 & 2024 & 2024 & 2048 & 2263 \\
\hline 1.00 & SAC305 & SAC305 & 235 & 3999 & 3999 & 4807 & 4807 & 1955 & 1955 & 2031 & 2031 \\
\hline 1.00 & SAC305 & SAC305 & 235 & 4282 & 4282 & 4406 & 4598 & 2123 & 2123 & 2123 & 2174 \\
\hline 1.00 & SAC305 & SAC305 & 235 & 5470 & 5471 & 5621 & 6012 & 2036 & 2036 & 2067 & 2423 \\
\hline 1.00 & SAC305 & SAC305 & 235 & 3715 & 3715 & 4650 & 5118 & 2333 & 2333 & 2406 & 2406 \\
\hline 1.00 & SAC305 & SAC305 & 235 & 5872 & 5873 & 5987 & 6311 & 1876 & 1876 & 1915 & 2133 \\
\hline 1.00 & SAC305 & SAC305 & 235 & 4831 & 4831 & 5515 & 5515 & 1772 & 1773 & 1785 & 1785 \\
\hline 1.00 & SAC305 & SAC305 & 235 & 5339 & 5339 & 5727 & 6912 & 2394 & 2394 & 2517 & 2564 \\
\hline 1.00 & SAC305 & SAC305 & 235 & 4425 & 4425 & 5157 & 6122 & 1861 & 1862 & 2073 & 2309 \\
\hline 1.00 & SAC305 & SAC305 & 235 & 4651 & 4652 & 6065 & 6702 & 1505 & 1505 & 1928 & 2290 \\
\hline 1.00 & SAC305 & SAC305 & 235 & 6220 & 6222 & 6290 & 7201 & 2152 & 2152 & 2166 & 2256 \\
\hline 1.00 & SAC305 & SAC305 & 235 & 5688 & 5689 & 6368 & 6864 & 1839 & 1839 & 1916 & 2420 \\
\hline 1.00 & SAC305 & SAC305 & 235 & 5192 & 5192 & 5843 & 5849 & 1859 & 1859 & 1979 & 2066 \\
\hline 1.00 & SAC305 & SAC105 & 235 & 2967 & 2967 & 2990 & 5055 & 1867 & 1867 & 1870 & 2113 \\
\hline 1.00 & SAC305 & SAC105 & 235 & 4846 & 4846 & 4933 & 5091 & 1437 & 1437 & 1439 & 1689 \\
\hline 1.00 & SAC305 & SAC105 & 235 & 4021 & 4021 & 4137 & 4658 & 1798 & 1798 & 1823 & 1873 \\
\hline 1.00 & SAC305 & SAC105 & 235 & 3790 & 3790 & 3821 & 5503 & 1052 & 1052 & 1057 & 1726 \\
\hline 1.00 & SAC305 & SAC105 & 235 & 3827 & 3827 & 3891 & 4370 & 1307 & 1307 & 1477 & 1547 \\
\hline 1.00 & SAC305 & SAC105 & 235 & 4437 & 4437 & 4943 & 5207 & 1480 & 1480 & 1504 & 1516 \\
\hline 1.00 & SAC305 & SAC105 & 235 & 4242 & 4242 & 4283 & 4847 & 1872 & 1872 & 1889 & 2036 \\
\hline 1.00 & SAC305 & SAC105 & 235 & 3581 & 3581 & 3727 & 3727 & 1587 & 1588 & 1679 & 1726 \\
\hline 1.00 & SAC305 & SAC105 & 235 & 2764 & 2764 & 3416 & 3661 & 1535 & 1535 & 1563 & 1563 \\
\hline 1.00 & SAC305 & SAC105 & 235 & 3867 & 3867 & 3880 & 4082 & 1822 & 1823 & 1837 & 2101 \\
\hline 1.00 & SAC305 & SAC105 & 235 & 3259 & 3260 & 3761 & 3761 & 1599 & 1599 & 1611 & 1735 \\
\hline 1.00 & SAC305 & SAC105 & 235 & 3590 & 3590 & 3830 & 3830 & 1238 & 1237 & 1301 & 1483 \\
\hline
\end{tabular}




\begin{tabular}{|c|c|c|c|c|c|c|c|c|c|c|c|}
\hline \multicolumn{4}{|c|}{ Treatment } & \multicolumn{4}{|c|}{$0^{\circ} \mathrm{C}$ to $100{ }^{\circ} \mathrm{C}$ TCR } & \multicolumn{4}{|c|}{$-40{ }^{\circ} \mathrm{C}$ to $125^{\circ} \mathrm{C}$ TCR } \\
\hline $\begin{array}{l}\text { Pkg } \\
\text { Desc } \\
(\mathrm{mm})\end{array}$ & $\begin{array}{l}\text { Paste } \\
\text { Alloy }\end{array}$ & $\begin{array}{c}\text { Ball } \\
\text { Alloy }\end{array}$ & $\begin{array}{l}\text { PRT } \\
\left({ }^{\circ} \mathbf{C}\right)\end{array}$ & $\underset{\text { and } R}{\overline{\mathbf{X}}}$ & $\begin{array}{l}\text { IPC- } \\
\text { 9701A }\end{array}$ & $500 \Omega$ & $\begin{array}{l}\text { Inf. } \\
\text { Resist. }\end{array}$ & $\underset{\text { and } R}{\overline{\mathbf{X}}}$ & $\begin{array}{l}\text { IPC- } \\
9701 \mathrm{~A}\end{array}$ & $500 \Omega$ & $\begin{array}{c}\text { Inf. } \\
\text { Resist. }\end{array}$ \\
\hline 1.00 & SAC305 & SAC105 & 235 & 3396 & 3396 & 3769 & 4187 & 1649 & 1649 & 1690 & 1787 \\
\hline 1.00 & SAC305 & SAC105 & 235 & 3977 & 3977 & 4268 & 4578 & 1471 & 1471 & 1481 & 1610 \\
\hline 1.00 & SAC305 & SAC105 & 235 & 3421 & 3421 & 3586 & 4669 & 1721 & 1721 & 1726 & 1913 \\
\hline 1.00 & SAC305 & SAC105 & 235 & 3795 & 3795 & 3982 & 5050 & 1721 & 1727 & 1763 & 2065 \\
\hline 1.00 & SAC305 & SAC105 & 235 & 3829 & 3829 & 4082 & 4272 & 1751 & 1751 & 1848 & 1891 \\
\hline 1.00 & SAC305 & SAC105 & 235 & 4418 & 4419 & 4419 & 4673 & 1673 & 1673 & 1678 & 1820 \\
\hline 1.00 & SAC305 & SAC105 & 235 & 3622 & 3622 & 3719 & 4957 & 1741 & 1741 & 1742 & 1826 \\
\hline 1.00 & SAC305 & SAC105 & 235 & 4412 & 4412 & 4721 & 4837 & 1399 & 1399 & 1428 & 1585 \\
\hline 1.00 & SAC305 & SACX & 235 & 3625 & 3625 & 3629 & 3783 & 1420 & 1420 & 1441 & 1521 \\
\hline 1.00 & SAC305 & SACX & 235 & 2484 & 2484 & 2551 & 2551 & 1111 & 1111 & 1281 & 1335 \\
\hline 1.00 & SAC305 & SACX & 235 & 3071 & 3071 & 3395 & 3395 & 1177 & 1177 & 1231 & 1343 \\
\hline 1.00 & SAC305 & SACX & 235 & 3957 & 3957 & 4027 & 4233 & 697 & 697 & 699 & 754 \\
\hline 1.00 & SAC305 & SACX & 235 & 3439 & 3440 & 4653 & 4653 & 1048 & 1048 & 1065 & 1097 \\
\hline 1.00 & SAC305 & SACX & 235 & 3571 & 3571 & 4071 & 4071 & 888 & 888 & 1036 & 1054 \\
\hline 1.00 & SAC305 & SACX & 235 & 3106 & 3106 & 3255 & 3562 & 1031 & 1031 & 1046 & 1413 \\
\hline 1.00 & SAC305 & SACX & 235 & 3023 & 3023 & 3157 & 3636 & 1117 & 1117 & 1144 & 1342 \\
\hline 1.00 & SAC305 & SACX & 235 & 2595 & 2595 & 2855 & 2855 & 995 & 995 & 1078 & 1273 \\
\hline 1.00 & SAC305 & SACX & 235 & 2783 & 2786 & 2839 & 3278 & 1248 & 1248 & 1254 & 1279 \\
\hline 1.00 & SAC305 & SACX & 235 & 2718 & 2719 & 2808 & 2808 & 1382 & 1383 & 1388 & 1437 \\
\hline 1.00 & SAC305 & SACX & 235 & 2680 & 2680 & 2736 & 2736 & 926 & 926 & 960 & 960 \\
\hline 1.00 & SAC305 & SACX & 235 & 3124 & 3125 & 3213 & 3551 & 1283 & 1287 & 1306 & 1410 \\
\hline 1.00 & SAC305 & SACX & 235 & 2965 & 2965 & 3545 & 3545 & 1179 & 1179 & 1185 & 1191 \\
\hline 1.00 & SAC305 & SACX & 235 & 2217 & 2217 & 2454 & 3317 & 1263 & 1263 & 1285 & 1429 \\
\hline 1.00 & SAC305 & SACX & 235 & 3326 & 3326 & 3571 & 3571 & 1178 & 1177 & 1306 & 1375 \\
\hline 1.00 & SAC305 & SACX & 235 & 2802 & 2802 & 2893 & 2893 & 1278 & 1278 & 1442 & 1442 \\
\hline 1.00 & SAC305 & SACX & 235 & 2814 & 2814 & 2900 & 3927 & 1248 & 1248 & 1263 & 1319 \\
\hline 1.00 & SAC305 & SACX & 235 & 3087 & 3087 & 3809 & 3861 & 1160 & 1160 & 1189 & 1198 \\
\hline 1.00 & SAC305 & SACX & 235 & 2951 & 2952 & 3373 & 3373 & 1158 & 1158 & 1202 & 1262 \\
\hline 1.00 & SAC305 & SAC205 & 235 & 4159 & 4164 & 4622 & 5271 & 1735 & 1735 & 1761 & 1998 \\
\hline 1.00 & SAC305 & SAC205 & 235 & 4455 & 4456 & 4586 & 5229 & 1700 & 1700 & 1706 & 1792 \\
\hline 1.00 & SAC305 & SAC205 & 235 & 3656 & 3659 & 4406 & 4406 & 1243 & 1243 & 1273 & 1424 \\
\hline 1.00 & SAC305 & SAC205 & 235 & 5018 & 5018 & 5608 & 5849 & 1822 & 1822 & 1823 & 2130 \\
\hline 1.00 & SAC305 & SAC205 & 235 & 128 & 129 & 139 & 223 & 1630 & 1630 & 1674 & 1839 \\
\hline 1.00 & SAC305 & SAC205 & 235 & 4297 & 4297 & 4321 & 6880 & 1392 & 1392 & 1394 & 1508 \\
\hline 1.00 & SAC305 & SAC205 & 235 & 3979 & 3979 & 4066 & 4422 & 1060 & 1060 & 1149 & 2098 \\
\hline 1.00 & SAC305 & SAC205 & 235 & 3335 & 3336 & 3630 & 4115 & 1716 & 1717 & 1749 & 2202 \\
\hline
\end{tabular}




\begin{tabular}{|c|c|c|c|c|c|c|c|c|c|c|c|}
\hline \multicolumn{4}{|c|}{ Treatment } & \multicolumn{4}{|c|}{$0^{\circ} \mathrm{C}$ to $100{ }^{\circ} \mathrm{C}$ TCR } & \multicolumn{4}{|c|}{$-40{ }^{\circ} \mathrm{C}$ to $125^{\circ} \mathrm{C}$ TCR } \\
\hline $\begin{array}{l}\text { Pkg } \\
\text { Desc } \\
(\mathrm{mm})\end{array}$ & $\begin{array}{l}\text { Paste } \\
\text { Alloy }\end{array}$ & $\begin{array}{c}\text { Ball } \\
\text { Alloy }\end{array}$ & $\begin{array}{l}\text { PRT } \\
\left({ }^{\circ} \mathbf{C}\right)\end{array}$ & $\underset{\text { and } R}{\bar{X}}$ & $\begin{array}{c}\text { IPC- } \\
\text { 9701A }\end{array}$ & $500 \Omega$ & $\begin{array}{l}\text { Inf. } \\
\text { Resist. }\end{array}$ & $\underset{\text { and } R}{\overline{\mathbf{X}}}$ & $\begin{array}{c}\text { IPC- } \\
\text { 9701A }\end{array}$ & $500 \Omega$ & $\begin{array}{c}\text { Inf. } \\
\text { Resist. }\end{array}$ \\
\hline 1.00 & SAC305 & SAC205 & 235 & 3436 & 3436 & 3956 & 4094 & 1414 & 1416 & 1474 & 1834 \\
\hline 1.00 & SAC305 & SAC205 & 235 & 4257 & 4257 & 4361 & 5102 & 1682 & 1682 & 1686 & 1860 \\
\hline 1.00 & SAC305 & SAC205 & 235 & 4015 & 4015 & 4085 & 5119 & 1701 & 1702 & 1773 & 2075 \\
\hline 1.00 & SAC305 & SAC205 & 235 & 4182 & 4182 & 4457 & 4458 & 1787 & 1787 & 1854 & 1863 \\
\hline 1.00 & SAC305 & SAC205 & 235 & 3911 & 3912 & 4382 & 5270 & 1199 & 1199 & 1207 & 1560 \\
\hline 1.00 & SAC305 & SAC205 & 235 & 4041 & 4042 & 4383 & 4791 & 1448 & 1448 & 1460 & 1583 \\
\hline 1.00 & SAC305 & SAC205 & 235 & 4898 & 4898 & 5087 & 5229 & 2075 & 2075 & 2076 & 2229 \\
\hline 1.00 & SAC305 & SAC205 & 235 & 5185 & 5185 & 5237 & 5467 & 1584 & 1585 & 1606 & 1609 \\
\hline 1.00 & SAC305 & SAC205 & 235 & 3717 & 3717 & 3892 & 4515 & 1391 & 1391 & 1405 & 1635 \\
\hline 1.00 & SAC305 & SAC205 & 235 & 4507 & 4507 & 4549 & 5087 & 1923 & 1923 & 1923 & 2078 \\
\hline 1.00 & SAC305 & SAC205 & 235 & 5139 & 5145 & 5630 & 5630 & 1748 & 1748 & 1750 & 1897 \\
\hline 1.00 & SAC305 & SAC205 & 235 & 3761 & 3761 & 4821 & 4905 & 1485 & 1485 & 1502 & 1727 \\
\hline 1.27 & SAC305 & SAC305 & 235 & n.f. & n.f. & n.f. & n.f. & 2497 & 2496 & 2497 & 2497 \\
\hline 1.27 & SAC305 & SAC305 & 235 & n.f. & n.f. & n.f. & n.f. & 2699 & 2698 & 2699 & 3497 \\
\hline 1.27 & SAC305 & SAC305 & 235 & 5178 & 5178 & 5208 & n.f. & 1447 & 1447 & 1454 & 2807 \\
\hline 1.27 & SAC305 & SAC305 & 235 & 9390 & 9390 & 9407 & n.f. & 3333 & 3333 & 3357 & 3365 \\
\hline 1.27 & SAC305 & SAC305 & 235 & 7059 & 7059 & 7059 & n.f. & 2333 & 2333 & 2340 & 2764 \\
\hline 1.27 & SAC305 & SAC305 & 235 & 7215 & 7215 & 7344 & n.f. & 3444 & 3444 & 3481 & 3513 \\
\hline 1.27 & SAC305 & SAC305 & 235 & n.f. & n.f. & n.f. & n.f. & 3401 & 3402 & 3402 & 3529 \\
\hline 1.27 & SAC305 & SAC305 & 235 & 10019 & 10022 & 10023 & n.f. & 2906 & 2906 & 2906 & 3508 \\
\hline 1.27 & SAC305 & SAC305 & 235 & 9444 & 9444 & 9484 & n.f. & n.f. & n.f. & n.f. & n.f. \\
\hline 1.27 & SAC305 & SAC305 & 235 & n.f. & n.f. & n.f. & n.f. & 1997 & 1999 & 2010 & 3281 \\
\hline 1.27 & SAC305 & SAC305 & 235 & 5558 & 5558 & 5601 & n.f. & 1919 & 1919 & 1946 & 3076 \\
\hline 1.27 & SAC305 & SAC305 & 235 & 5768 & 5768 & 5907 & n.f. & 3327 & 3327 & 3340 & 3521 \\
\hline 1.27 & SAC305 & SAC305 & 235 & n.f. & n.f. & n.f. & n.f. & 2741 & 2741 & 2770 & 3550 \\
\hline 1.27 & SAC305 & SAC305 & 235 & 10012 & 10016 & 10076 & n.f. & 2342 & 2342 & 2349 & 3531 \\
\hline 1.27 & SAC305 & SAC305 & 235 & n.f. & n.f. & n.f. & n.f. & 3378 & 3378 & 3489 & 3489 \\
\hline 1.27 & SAC305 & SAC305 & 235 & n.f. & n.f. & n.f. & n.f. & 2012 & 2012 & 2109 & 2882 \\
\hline 1.27 & SAC305 & SAC305 & 235 & n.f. & n.f. & n.f. & n.f. & 2630 & 2630 & 2718 & 3357 \\
\hline 1.27 & SAC305 & SAC305 & 235 & n.f. & n.f. & n.f. & n.f. & 3117 & 3117 & 3117 & 3482 \\
\hline 1.27 & SAC305 & SAC305 & 235 & 6008 & 6014 & 6074 & n.f. & 1939 & 1939 & 1942 & 3457 \\
\hline 1.27 & SAC305 & SAC305 & 235 & n.f. & n.f. & n.f. & n.f. & 2750 & 2750 & 2750 & 3090 \\
\hline 1.27 & SAC305 & SAC105 & 235 & 6525 & 6527 & 6534 & n.f. & 3464 & 3464 & 3467 & 3548 \\
\hline 1.27 & SAC305 & SAC105 & 235 & 4347 & 4347 & 4365 & 4785 & 654 & 654 & 664 & 1567 \\
\hline 1.27 & SAC305 & SAC105 & 235 & 4239 & 4239 & 4277 & n.f. & 2050 & 2050 & 2058 & 3007 \\
\hline 1.27 & SAC305 & SAC105 & 235 & 7434 & 7434 & 7436 & n.f. & 2405 & 2405 & 2413 & 3555 \\
\hline
\end{tabular}




\begin{tabular}{|c|c|c|c|c|c|c|c|c|c|c|c|}
\hline \multicolumn{4}{|c|}{ Treatment } & \multicolumn{4}{|c|}{$0^{\circ} \mathrm{C}$ to $100{ }^{\circ} \mathrm{C}$ TCR } & \multicolumn{4}{|c|}{$-40{ }^{\circ} \mathrm{C}$ to $125^{\circ} \mathrm{C}$ TCR } \\
\hline $\begin{array}{l}\text { Pkg } \\
\text { Desc } \\
(\mathrm{mm})\end{array}$ & $\begin{array}{l}\text { Paste } \\
\text { Alloy }\end{array}$ & $\begin{array}{c}\text { Ball } \\
\text { Alloy }\end{array}$ & $\begin{array}{l}\text { PRT } \\
\left({ }^{\circ} \mathbf{C}\right)\end{array}$ & $\underset{\text { and } R}{\overline{\mathbf{X}}}$ & $\begin{array}{l}\text { IPC- } \\
\text { 9701A }\end{array}$ & $500 \Omega$ & $\begin{array}{l}\text { Inf. } \\
\text { Resist. }\end{array}$ & $\underset{\text { and } R}{\overline{\mathbf{X}}}$ & $\begin{array}{c}\text { IPC- } \\
\text { 9701A }\end{array}$ & $500 \Omega$ & $\begin{array}{c}\text { Inf. } \\
\text { Resist. }\end{array}$ \\
\hline 1.27 & SAC305 & SAC105 & 235 & 5386 & 5386 & 5388 & 9174 & n.f. & n.f. & n.f. & n.f. \\
\hline 1.27 & SAC305 & SAC105 & 235 & 8789 & 8789 & 8789 & n.f. & n.f. & n.f. & n.f. & n.f. \\
\hline 1.27 & SAC305 & SAC105 & 235 & 5326 & 5326 & 5326 & n.f. & 2868 & 2868 & 2888 & 3551 \\
\hline 1.27 & SAC305 & SAC105 & 235 & 4990 & 4990 & 4991 & n.f. & 1873 & 1873 & 1876 & 1884 \\
\hline 1.27 & SAC305 & SAC105 & 235 & 5071 & 5071 & 5073 & n.f. & 2528 & 2529 & 2532 & 3488 \\
\hline 1.27 & SAC305 & SAC105 & 235 & n.f. & n.f. & n.f. & n.f. & 2590 & 2591 & 2591 & 3138 \\
\hline 1.27 & SAC305 & SAC105 & 235 & 4953 & 4953 & 4964 & n.f. & 2170 & 2170 & 2173 & 3247 \\
\hline 1.27 & SAC305 & SAC105 & 235 & 5013 & 5013 & 5095 & n.f. & 1379 & 1379 & 1384 & 3295 \\
\hline 1.27 & SAC305 & SAC105 & 235 & 4243 & 4242 & 4253 & n.f. & 1907 & 1907 & 1908 & 3235 \\
\hline 1.27 & SAC305 & SAC105 & 235 & 3465 & 3465 & 3502 & n.f. & 945 & 945 & 948 & 967 \\
\hline 1.27 & SAC305 & SAC105 & 235 & n.f. & n.f. & n.f. & n.f. & 1976 & 1976 & 1984 & 3327 \\
\hline 1.27 & SAC305 & SAC105 & 235 & 3939 & 3939 & 3968 & 4999 & 1961 & 1961 & 1964 & 3428 \\
\hline 1.27 & SAC305 & SAC105 & 235 & n.f. & n.f. & n.f. & n.f. & 1435 & 1435 & 1436 & 1616 \\
\hline 1.27 & SAC305 & SAC105 & 235 & n.f. & n.f. & n.f. & n.f. & 2032 & 2033 & 2033 & 3542 \\
\hline 1.27 & SAC305 & SAC105 & 235 & 5459 & 5459 & 5579 & n.f. & 1291 & 1290 & 1300 & 1357 \\
\hline 1.27 & SAC305 & SAC105 & 235 & n.f. & n.f. & n.f. & n.f. & 2207 & 2207 & 2207 & 3387 \\
\hline 1.27 & SAC305 & SACX & 235 & 6113 & 6113 & 6113 & n.f. & 1208 & 1208 & 1209 & 2794 \\
\hline 1.27 & SAC305 & SACX & 235 & 2891 & 2890 & 2910 & 3021 & 1547 & 1547 & 1548 & 1591 \\
\hline 1.27 & SAC305 & SACX & 235 & 3634 & 3634 & 3639 & 3891 & 1219 & 1219 & 1220 & 1616 \\
\hline 1.27 & SAC305 & SACX & 235 & n.f. & n.f. & n.f. & n.f. & 1620 & 1620 & 1621 & 1754 \\
\hline 1.27 & SAC305 & SACX & 235 & 5110 & 5110 & 5114 & n.f. & 1375 & 1375 & 1377 & 1694 \\
\hline 1.27 & SAC305 & SACX & 235 & 6366 & 6397 & 6404 & n.f. & 1957 & 1957 & 1961 & 2251 \\
\hline 1.27 & SAC305 & SACX & 235 & 3889 & 3889 & 3891 & n.f. & 2955 & 2954 & 2955 & 3003 \\
\hline 1.27 & SAC305 & SACX & 235 & 4443 & 4443 & 4447 & 7414 & 1608 & 1608 & 1608 & 2360 \\
\hline 1.27 & SAC305 & SACX & 235 & 4050 & 4050 & 4065 & 5005 & 1047 & 1047 & 1058 & 1926 \\
\hline 1.27 & SAC305 & SACX & 235 & 6159 & 6159 & 6159 & 8437 & 2100 & 2100 & 2104 & 2477 \\
\hline 1.27 & SAC305 & SACX & 235 & 3719 & 3719 & 3730 & 6092 & 1932 & 1933 & 1933 & 2674 \\
\hline 1.27 & SAC305 & SACX & 235 & 4720 & 4720 & 4794 & 4873 & 1115 & 1116 & 1116 & 1322 \\
\hline 1.27 & SAC305 & SACX & 235 & 4533 & 4533 & 4533 & 7622 & 823 & 823 & 823 & 1545 \\
\hline 1.27 & SAC305 & SACX & 235 & 5351 & 5351 & 5367 & 5675 & 1242 & 1242 & 1243 & 2259 \\
\hline 1.27 & SAC305 & SACX & 235 & 7553 & 7553 & 7605 & 10046 & 1674 & 1674 & 1690 & 2872 \\
\hline 1.27 & SAC305 & SACX & 235 & 3754 & 3754 & 3758 & 4203 & 1341 & 1341 & 1366 & 1482 \\
\hline 1.27 & SAC305 & SACX & 235 & 3809 & 3809 & 3092 & 3410 & 1973 & 1973 & 1980 & 2101 \\
\hline 1.27 & SAC305 & SACX & 235 & 5516 & 5516 & 5516 & 6340 & 1759 & 1760 & 1760 & 3310 \\
\hline 1.27 & SAC305 & SACX & 235 & 2733 & 2733 & 2745 & 3505 & 1551 & 1551 & 1552 & 1676 \\
\hline 1.27 & SAC305 & SACX & 235 & 3656 & 3656 & 3683 & 6361 & 1021 & 1020 & 1023 & 1149 \\
\hline
\end{tabular}




\begin{tabular}{|c|c|c|c|c|c|c|c|c|c|c|c|}
\hline \multicolumn{4}{|c|}{ Treatment } & \multicolumn{4}{|c|}{$0^{\circ} \mathrm{C}$ to $100^{\circ} \mathrm{C}$ TCR } & \multicolumn{4}{|c|}{$-40^{\circ} \mathrm{C}$ to $125^{\circ} \mathrm{C}$ TCR } \\
\hline $\begin{array}{c}\text { Pkg } \\
\text { Desc } \\
(\mathrm{mm})\end{array}$ & $\begin{array}{l}\text { Paste } \\
\text { Alloy }\end{array}$ & $\begin{array}{c}\text { Ball } \\
\text { Alloy }\end{array}$ & $\begin{array}{l}\text { PRT } \\
\left({ }^{\circ} \mathrm{C}\right)\end{array}$ & $\underset{\text { and } R}{\overline{\mathbf{X}}}$ & $\begin{array}{l}\text { IPC- } \\
\text { 9701A }\end{array}$ & $500 \Omega$ & $\begin{array}{l}\text { Inf. } \\
\text { Resist. }\end{array}$ & $\underset{\text { and } R}{\bar{X}}$ & $\begin{array}{c}\text { IPC- } \\
9701 \mathrm{~A}\end{array}$ & $500 \Omega$ & $\begin{array}{c}\text { Inf. } \\
\text { Resist. }\end{array}$ \\
\hline 1.27 & SAC305 & SAC205 & 235 & 6005 & 6005 & 6005 & n.f. & 3348 & 3348 & 3349 & 3379 \\
\hline 1.27 & SAC305 & SAC205 & 235 & 4616 & 4616 & 4622 & n.f. & 3059 & 3059 & 3059 & 3059 \\
\hline 1.27 & SAC305 & SAC205 & 235 & 4968 & 4970 & 4980 & n.f. & 2975 & 2976 & 3002 & 3112 \\
\hline 1.27 & SAC305 & SAC205 & 235 & 6123 & 6123 & 6125 & n.f. & 2877 & 2877 & 2877 & 3541 \\
\hline 1.27 & SAC305 & SAC205 & 235 & 3619 & 3619 & 3638 & n.f. & 1738 & 1738 & 1743 & 3118 \\
\hline 1.27 & SAC305 & SAC205 & 235 & 3789 & 3789 & 3799 & 9170 & 2154 & 2154 & 2154 & 2796 \\
\hline 1.27 & SAC305 & SAC205 & 235 & n.f. & n.f. & n.f. & n.f. & 3498 & 3499 & 3504 & 3542 \\
\hline 1.27 & SAC305 & SAC205 & 235 & 3945 & 3945 & 3950 & n.f. & 1352 & 1352 & 1355 & 2949 \\
\hline 1.27 & SAC305 & SAC205 & 235 & 9624 & 9627 & 9649 & n.f. & 1233 & 1233 & 1233 & 1264 \\
\hline 1.27 & SAC305 & SAC205 & 235 & 5389 & 5390 & 5428 & n.f. & 3183 & 3184 & 3184 & 3518 \\
\hline 1.27 & SAC305 & SAC205 & 235 & 5004 & 5004 & 5007 & n.f. & 1754 & 1754 & 1755 & 3534 \\
\hline 1.27 & SAC305 & SAC205 & 235 & 6697 & 6697 & 6711 & n.f. & 3061 & 3061 & 3069 & 3522 \\
\hline 1.27 & SAC305 & SAC205 & 235 & 8041 & 8042 & 8101 & n.f. & 2656 & 2654 & 2671 & 2803 \\
\hline 1.27 & SAC305 & SAC205 & 235 & 4482 & 4482 & 4563 & 6736 & 1481 & 1481 & 1483 & 3546 \\
\hline 1.27 & SAC305 & SAC205 & 235 & 6574 & 6574 & 6584 & 7582 & 3364 & 3364 & 3364 & 3550 \\
\hline 1.27 & SAC305 & SAC205 & 235 & 5100 & 5100 & 5179 & 6279 & 2716 & 2717 & 2722 & 3512 \\
\hline 1.27 & SAC305 & SAC205 & 235 & 3145 & 3145 & 3148 & 3346 & 3130 & 3130 & 3132 & 3525 \\
\hline 1.27 & SAC305 & SAC205 & 235 & 4835 & 4835 & 4847 & n.f. & 3072 & 3072 & 3073 & 3543 \\
\hline 1.27 & SAC305 & SAC205 & 235 & 6111 & 6111 & 6119 & n.f. & 2282 & 2282 & 2285 & 2765 \\
\hline 1.27 & SAC305 & SAC205 & 235 & 4726 & 4726 & 4734 & 5719 & 1757 & 1757 & 1758 & 2599 \\
\hline 0.50 & $\mathrm{SnPb}$ & $\mathrm{SnPb}$ & 215 & 1581 & 1582 & 1743 & 1743 & 915 & 915 & 928 & 928 \\
\hline 0.50 & $\mathrm{SnPb}$ & $\mathrm{SnPb}$ & 215 & 1688 & 1688 & 1996 & 1996 & 989 & 989 & 1062 & 1062 \\
\hline 0.50 & $\mathrm{SnPb}$ & $\mathrm{SnPb}$ & 215 & 1410 & 1411 & 1453 & 1453 & 724 & 724 & 735 & 735 \\
\hline 0.50 & $\mathrm{SnPb}$ & $\mathrm{SnPb}$ & 215 & 1774 & 1774 & 1867 & 1867 & 956 & 955 & 972 & 972 \\
\hline 0.50 & $\mathrm{SnPb}$ & $\mathrm{SnPb}$ & 215 & 1843 & 1844 & 1970 & 1970 & 1094 & 1094 & 1163 & 1163 \\
\hline 0.50 & $\mathrm{SnPb}$ & $\mathrm{SnPb}$ & 215 & n.f. & n.f. & n.f. & n.f. & 689 & 689 & 739 & 739 \\
\hline 0.50 & $\mathrm{SnPb}$ & $\mathrm{SnPb}$ & 215 & 1847 & 1847 & 1983 & 1983 & 957 & 957 & 1006 & 1006 \\
\hline 0.50 & $\mathrm{SnPb}$ & $\mathrm{SnPb}$ & 215 & 1900 & 1900 & 2075 & 2075 & 885 & 886 & 895 & 895 \\
\hline 0.50 & $\mathrm{SnPb}$ & $\mathrm{SnPb}$ & 215 & 1542 & 1542 & 1733 & 1733 & 840 & 840 & 868 & 868 \\
\hline 0.50 & $\mathrm{SnPb}$ & $\mathrm{SnPb}$ & 215 & 2071 & 2071 & 2224 & 2224 & 946 & 946 & 966 & 966 \\
\hline 0.50 & $\mathrm{SnPb}$ & $\mathrm{SnPb}$ & 215 & 1721 & 1722 & 1769 & 1769 & 989 & 989 & 1004 & 1004 \\
\hline 0.50 & $\mathrm{SnPb}$ & $\mathrm{SnPb}$ & 215 & 1547 & 1548 & 1647 & 1647 & 956 & 955 & 998 & 998 \\
\hline 0.50 & $\mathrm{SnPb}$ & $\mathrm{SnPb}$ & 215 & 1770 & 1770 & 1813 & 1813 & 1257 & 1257 & 1325 & 1325 \\
\hline 0.50 & $\mathrm{SnPb}$ & $\mathrm{SnPb}$ & 215 & 1355 & 1355 & 1471 & 1471 & 1059 & 1059 & 1075 & 1075 \\
\hline 0.50 & $\mathrm{SnPb}$ & $\mathrm{SnPb}$ & 215 & 1709 & 1709 & 1766 & 1766 & 972 & 972 & 1042 & 1042 \\
\hline 0.50 & $\mathrm{SnPb}$ & $\mathrm{SnPb}$ & 215 & 2072 & 2072 & 2235 & 2235 & 1173 & 1173 & 1223 & 1223 \\
\hline
\end{tabular}




\begin{tabular}{|c|c|c|c|c|c|c|c|c|c|c|c|}
\hline \multicolumn{4}{|c|}{ Treatment } & \multicolumn{4}{|c|}{$0^{\circ} \mathrm{C}$ to $100{ }^{\circ} \mathrm{C}$ TCR } & \multicolumn{4}{|c|}{$-40{ }^{\circ} \mathrm{C}$ to $125^{\circ} \mathrm{C}$ TCR } \\
\hline $\begin{array}{l}\text { Pkg } \\
\text { Desc } \\
(\mathrm{mm})\end{array}$ & $\begin{array}{l}\text { Paste } \\
\text { Alloy }\end{array}$ & $\begin{array}{c}\text { Ball } \\
\text { Alloy }\end{array}$ & $\begin{array}{l}\text { PRT } \\
\left({ }^{\circ} \mathbf{C}\right)\end{array}$ & $\underset{\text { and } R}{\overline{\mathbf{X}}}$ & $\begin{array}{l}\text { IPC- } \\
\text { 9701A }\end{array}$ & $500 \Omega$ & $\begin{array}{l}\text { Inf. } \\
\text { Resist. }\end{array}$ & $\underset{\text { and } R}{\overline{\mathbf{X}}}$ & $\begin{array}{c}\text { IPC- } \\
\text { 9701A }\end{array}$ & $500 \Omega$ & $\begin{array}{l}\text { Inf. } \\
\text { Resist. }\end{array}$ \\
\hline 0.50 & $\mathrm{SnPb}$ & $\mathrm{SnPb}$ & 215 & 1639 & 1639 & 1848 & 1848 & 901 & 901 & 985 & 985 \\
\hline 0.50 & $\mathrm{SnPb}$ & $\mathrm{SnPb}$ & 215 & 2008 & 2008 & 2172 & 2172 & 950 & 950 & 1003 & 1003 \\
\hline 0.50 & $\mathrm{SnPb}$ & $\mathrm{SnPb}$ & 215 & 1919 & 1919 & 2038 & 2038 & 1083 & 1084 & 1109 & 1109 \\
\hline 0.50 & $\mathrm{SnPb}$ & $\mathrm{SnPb}$ & 215 & 1585 & 1585 & 1731 & 1731 & 717 & 717 & 740 & 740 \\
\hline 0.50 & $\mathrm{SnPb}$ & SAC305 & 215 & 2581 & 2581 & 3210 & 3210 & 861 & 867 & 1416 & 1416 \\
\hline 0.50 & $\mathrm{SnPb}$ & SAC305 & 215 & 3019 & 3025 & 3777 & 3777 & 1401 & 1401 & 1523 & 1523 \\
\hline 0.50 & $\mathrm{SnPb}$ & SAC305 & 215 & 2653 & 2658 & 3706 & 3706 & 509 & 509 & 928 & 928 \\
\hline 0.50 & $\mathrm{SnPb}$ & SAC305 & 215 & 2586 & 2590 & 3282 & 3282 & 1166 & 1167 & 1710 & 1710 \\
\hline 0.50 & $\mathrm{SnPb}$ & SAC305 & 215 & 2750 & 2751 & 3499 & 3499 & 623 & 629 & 1393 & 1393 \\
\hline 0.50 & $\mathrm{SnPb}$ & SAC305 & 215 & 2394 & 2406 & 3448 & 3448 & 933 & 933 & 1606 & 1606 \\
\hline 0.50 & $\mathrm{SnPb}$ & SAC305 & 215 & 2590 & 2596 & 3488 & 3488 & 1120 & 1121 & 1488 & 1488 \\
\hline 0.50 & $\mathrm{SnPb}$ & SAC305 & 215 & 3493 & 3493 & 3500 & 4291 & 628 & 641 & 938 & 938 \\
\hline 0.50 & $\mathrm{SnPb}$ & SAC305 & 215 & 2724 & 2725 & 2727 & 4423 & 1066 & 1066 & 1255 & 1255 \\
\hline 0.50 & $\mathrm{SnPb}$ & SAC305 & 215 & 2714 & 2714 & 3477 & 3477 & 997 & 998 & 1511 & 1511 \\
\hline 0.50 & $\mathrm{SnPb}$ & SAC305 & 215 & 2861 & 2861 & 3881 & 3881 & 1532 & 1552 & 1939 & 1939 \\
\hline 0.50 & $\mathrm{SnPb}$ & SAC305 & 215 & 2214 & 2214 & 3454 & 3454 & 1266 & 1266 & 1728 & 1728 \\
\hline 0.50 & $\mathrm{SnPb}$ & SAC305 & 215 & 2125 & 2127 & 3082 & 3082 & 985 & 985 & 1035 & 1035 \\
\hline 0.50 & $\mathrm{SnPb}$ & SAC305 & 215 & 2103 & 2103 & 3092 & 3092 & 944 & 950 & 1304 & 1304 \\
\hline 0.50 & $\mathrm{SnPb}$ & SAC305 & 215 & 2647 & 2723 & 3012 & 3012 & 1156 & 1156 & 1460 & 1460 \\
\hline 0.50 & $\mathrm{SnPb}$ & SAC305 & 215 & 6524 & 6525 & 6888 & 7528 & 1127 & 1127 & 1194 & 1194 \\
\hline 0.50 & $\mathrm{SnPb}$ & SAC305 & 215 & 3263 & 3264 & 3777 & 3777 & 1182 & 1182 & 1377 & 1377 \\
\hline 0.50 & $\mathrm{SnPb}$ & SAC305 & 215 & 2811 & 2814 & 3353 & 3353 & 1674 & 1675 & 1880 & 2020 \\
\hline 0.50 & $\mathrm{SnPb}$ & SAC305 & 215 & 2920 & 2922 & 3326 & 3467 & 1668 & 1668 & 1784 & 1784 \\
\hline 0.50 & $\mathrm{SnPb}$ & SAC305 & 215 & 2184 & 2185 & 3358 & 3358 & 1241 & 1242 & 1488 & 1488 \\
\hline 0.50 & $\mathrm{SnPb}$ & SAC105 & 215 & 2738 & 2745 & 2959 & 2959 & 1003 & 1005 & 1786 & 1786 \\
\hline 0.50 & $\mathrm{SnPb}$ & SAC105 & 215 & 3069 & 3069 & 3424 & 3424 & 1251 & 1251 & 1634 & 1634 \\
\hline 0.50 & $\mathrm{SnPb}$ & SAC105 & 215 & 2762 & 2763 & 3157 & 3157 & 1512 & 1512 & 1724 & 1724 \\
\hline 0.50 & $\mathrm{SnPb}$ & SAC105 & 215 & 2247 & 2247 & 2804 & 2804 & 1183 & 1184 & 1472 & 1472 \\
\hline 0.50 & $\mathrm{SnPb}$ & SAC105 & 215 & 2650 & 2654 & 3156 & 3156 & 1287 & 1290 & 1430 & 1430 \\
\hline 0.50 & $\mathrm{SnPb}$ & SAC105 & 215 & 2907 & 2907 & 3499 & 3499 & 991 & 992 & 1499 & 1499 \\
\hline 0.50 & $\mathrm{SnPb}$ & SAC105 & 215 & 3060 & 3061 & 3619 & 3619 & 852 & 852 & 1115 & 1115 \\
\hline 0.50 & $\mathrm{SnPb}$ & SAC105 & 215 & 3028 & 3050 & 3648 & 3648 & 671 & 692 & 1553 & 1553 \\
\hline 0.50 & $\mathrm{SnPb}$ & SAC105 & 215 & 2513 & 2513 & 2983 & 2983 & 1302 & 1308 & 1677 & 1694 \\
\hline 0.50 & $\mathrm{SnPb}$ & SAC105 & 215 & 2552 & 2552 & 3167 & 3167 & 1437 & 1437 & 1528 & 1528 \\
\hline 0.50 & $\mathrm{SnPb}$ & SAC105 & 215 & 2351 & 2352 & 2714 & 2714 & 1243 & 1243 & 1590 & 1590 \\
\hline 0.50 & $\mathrm{SnPb}$ & SAC105 & 215 & 2736 & 2736 & 3370 & 3370 & 737 & 744 & 1255 & 1255 \\
\hline
\end{tabular}




\begin{tabular}{|c|c|c|c|c|c|c|c|c|c|c|c|}
\hline \multicolumn{4}{|c|}{ Treatment } & \multicolumn{4}{|c|}{$0^{\circ} \mathrm{C}$ to $100{ }^{\circ} \mathrm{C}$ TCR } & \multicolumn{4}{|c|}{$-40{ }^{\circ} \mathrm{C}$ to $125^{\circ} \mathrm{C}$ TCR } \\
\hline $\begin{array}{l}\text { Pkg } \\
\text { Desc } \\
(\mathrm{mm})\end{array}$ & $\begin{array}{l}\text { Paste } \\
\text { Alloy }\end{array}$ & $\begin{array}{c}\text { Ball } \\
\text { Alloy }\end{array}$ & $\begin{array}{l}\text { PRT } \\
\left({ }^{\circ} \mathbf{C}\right)\end{array}$ & $\underset{\text { and } R}{\overline{\mathbf{X}}}$ & $\begin{array}{l}\text { IPC- } \\
\text { 9701A }\end{array}$ & $500 \Omega$ & $\begin{array}{l}\text { Inf. } \\
\text { Resist. }\end{array}$ & $\underset{\text { and } R}{\overline{\mathbf{X}}}$ & $\begin{array}{l}\text { IPC- } \\
9701 \mathrm{~A}\end{array}$ & $500 \Omega$ & $\begin{array}{c}\text { Inf. } \\
\text { Resist. }\end{array}$ \\
\hline 0.50 & $\mathrm{SnPb}$ & SAC105 & 215 & 2771 & 2848 & 3017 & 3017 & 1294 & 1294 & 1429 & 1576 \\
\hline 0.50 & $\mathrm{SnPb}$ & SAC105 & 215 & 2725 & 2725 & 3394 & 3394 & 994 & 994 & 1161 & 1161 \\
\hline 0.50 & $\mathrm{SnPb}$ & SAC105 & 215 & 3432 & 3432 & 4139 & 4139 & 1096 & 1096 & 1617 & 1617 \\
\hline 0.50 & $\mathrm{SnPb}$ & SAC105 & 215 & 2790 & 2813 & 3500 & 3500 & 1245 & 1245 & 1377 & 1377 \\
\hline 0.50 & $\mathrm{SnPb}$ & SAC105 & 215 & 2478 & 2479 & 2927 & 2927 & 714 & 720 & 1157 & 1157 \\
\hline 0.50 & $\mathrm{SnPb}$ & SAC105 & 215 & 2805 & 2805 & 3454 & 3454 & 1885 & 1886 & 2102 & 2102 \\
\hline 0.50 & $\mathrm{SnPb}$ & SAC105 & 215 & 2941 & 2943 & 3467 & 3467 & 1239 & 1239 & 1638 & 1638 \\
\hline 0.50 & $\mathrm{SnPb}$ & SAC105 & 215 & 2069 & 2070 & 3081 & 3081 & 1208 & 1208 & 1318 & 1318 \\
\hline 0.50 & $\mathrm{SnPb}$ & SACX & 215 & 3176 & 3176 & 4175 & 4175 & 1443 & 1444 & 1722 & 1997 \\
\hline 0.50 & $\mathrm{SnPb}$ & SACX & 215 & 3316 & 3324 & 3827 & 4266 & 1062 & 1063 & 1805 & 1805 \\
\hline 0.50 & $\mathrm{SnPb}$ & SACX & 215 & 2570 & 2571 & 3504 & 3504 & 241 & 246 & 635 & 635 \\
\hline 0.50 & $\mathrm{SnPb}$ & SACX & 215 & 3852 & 3854 & 4652 & 4652 & 1166 & 1170 & 1855 & 1855 \\
\hline 0.50 & $\mathrm{SnPb}$ & SACX & 215 & 3623 & 3627 & 4618 & 4618 & 979 & 981 & 1925 & 2034 \\
\hline 0.50 & $\mathrm{SnPb}$ & SACX & 215 & 2811 & 2839 & 3666 & 3666 & 223 & 231 & 643 & 643 \\
\hline 0.50 & $\mathrm{SnPb}$ & SACX & 215 & 2802 & 2802 & 3363 & 3363 & 1176 & 1190 & 1894 & 1894 \\
\hline 0.50 & $\mathrm{SnPb}$ & SACX & 215 & 2735 & 2738 & 3777 & 3777 & 1441 & 1457 & 1913 & 1957 \\
\hline 0.50 & $\mathrm{SnPb}$ & SACX & 215 & 2249 & 2249 & 3528 & 3528 & 668 & 668 & 2064 & 2064 \\
\hline 0.50 & $\mathrm{SnPb}$ & SACX & 215 & 2887 & 2893 & 3514 & 3514 & 1846 & 1848 & 2212 & 2212 \\
\hline 0.50 & $\mathrm{SnPb}$ & SACX & 215 & 3289 & 3289 & 3381 & 3706 & 1614 & 1614 & 1846 & 1846 \\
\hline 0.50 & $\mathrm{SnPb}$ & SACX & 215 & 2131 & 2193 & 3219 & 3219 & 753 & 753 & 1657 & 1657 \\
\hline 0.50 & $\mathrm{SnPb}$ & SACX & 215 & 2460 & 2465 & 3300 & 3300 & 997 & 997 & 1364 & 1364 \\
\hline 0.50 & $\mathrm{SnPb}$ & SACX & 215 & 2476 & 2476 & 3289 & 3289 & 1083 & 1085 & 1377 & 1377 \\
\hline 0.50 & $\mathrm{SnPb}$ & SACX & 215 & 3406 & 3413 & 3747 & 3747 & 1677 & 1682 & 1984 & 1984 \\
\hline 0.50 & $\mathrm{SnPb}$ & SACX & 215 & 2825 & 2826 & 4100 & 4100 & 593 & 597 & 1626 & 1827 \\
\hline 0.50 & $\mathrm{SnPb}$ & SACX & 215 & 2014 & 2125 & 4473 & 4473 & 1477 & 1489 & 1861 & 1923 \\
\hline 0.50 & $\mathrm{SnPb}$ & SACX & 215 & 3488 & 3492 & 4083 & 4083 & 1892 & 1892 & 2179 & 2179 \\
\hline 0.50 & $\mathrm{SnPb}$ & SACX & 215 & 3400 & 3410 & 4596 & 4596 & 1989 & 1992 & 2189 & 2402 \\
\hline 0.50 & $\mathrm{SnPb}$ & SACX & 215 & 1985 & 1994 & 3660 & 3660 & 535 & 536 & 1135 & 1135 \\
\hline 0.50 & $\mathrm{SnPb}$ & LF35 & 215 & 3456 & 3459 & 3589 & 3738 & 1177 & 1180 & 1470 & 1618 \\
\hline 0.50 & $\mathrm{SnPb}$ & LF35 & 215 & 2568 & 2573 & 4433 & 4433 & 645 & 646 & 1683 & 1683 \\
\hline 0.50 & $\mathrm{SnPb}$ & LF35 & 215 & 2812 & 2812 & 3737 & 3737 & 1358 & 1362 & 1839 & 1839 \\
\hline 0.50 & $\mathrm{SnPb}$ & LF35 & 215 & 2517 & 2518 & 3934 & 4382 & 1252 & 1252 & 1608 & 1608 \\
\hline 0.50 & $\mathrm{SnPb}$ & LF35 & 215 & 3380 & 3393 & 4382 & 4382 & 1711 & 1719 & 1810 & 1810 \\
\hline 0.50 & $\mathrm{SnPb}$ & LF35 & 215 & 3009 & 3133 & 4462 & 4462 & 1451 & 1453 & 2069 & 2069 \\
\hline 0.50 & $\mathrm{SnPb}$ & LF35 & 215 & 2542 & 2543 & 3510 & 3510 & 735 & 739 & 1418 & 1478 \\
\hline 0.50 & $\mathrm{SnPb}$ & LF35 & 215 & 3205 & 3206 & 3928 & 4482 & 1124 & 1124 & 1166 & 1166 \\
\hline
\end{tabular}




\begin{tabular}{|c|c|c|c|c|c|c|c|c|c|c|c|}
\hline \multicolumn{4}{|c|}{ Treatment } & \multicolumn{4}{|c|}{$0^{\circ} \mathrm{C}$ to $100{ }^{\circ} \mathrm{C}$ TCR } & \multicolumn{4}{|c|}{$-40{ }^{\circ} \mathrm{C}$ to $125^{\circ} \mathrm{C}$ TCR } \\
\hline $\begin{array}{l}\text { Pkg } \\
\text { Desc } \\
(\mathrm{mm})\end{array}$ & $\begin{array}{l}\text { Paste } \\
\text { Alloy }\end{array}$ & $\begin{array}{l}\text { Ball } \\
\text { Alloy }\end{array}$ & $\begin{array}{l}\text { PRT } \\
\left({ }^{\circ} \mathrm{C}\right)\end{array}$ & $\underset{\text { and } R}{\overline{\mathbf{X}}}$ & $\begin{array}{c}\text { IPC- } \\
9701 A\end{array}$ & $500 \Omega$ & $\begin{array}{l}\text { Inf. } \\
\text { Resist. }\end{array}$ & $\underset{\text { and } R}{\overline{\mathbf{X}}}$ & $\begin{array}{c}\text { IPC- } \\
9701 \mathrm{~A}\end{array}$ & $500 \Omega$ & $\begin{array}{l}\text { Inf. } \\
\text { Resist. }\end{array}$ \\
\hline 0.50 & $\mathrm{SnPb}$ & LF35 & 215 & 3608 & 3636 & 4770 & 4882 & 1019 & 1024 & 1326 & 1326 \\
\hline 0.50 & $\mathrm{SnPb}$ & LF35 & 215 & 3599 & 3601 & 3844 & 4049 & 1554 & 1556 & 1738 & 1906 \\
\hline 0.50 & $\mathrm{SnPb}$ & LF35 & 215 & 3693 & 3693 & 3885 & 4567 & 1430 & 1430 & 1624 & 1624 \\
\hline 0.50 & $\mathrm{SnPb}$ & LF35 & 215 & 2621 & 2632 & 3972 & 3972 & 998 & 998 & 1548 & 1548 \\
\hline 0.50 & $\mathrm{SnPb}$ & LF35 & 215 & 1579 & 1579 & 2772 & 2772 & 1418 & 1418 & 1799 & 1875 \\
\hline 0.50 & $\mathrm{SnPb}$ & LF35 & 215 & 2802 & 2804 & 3188 & 3188 & 1029 & 1030 & 1280 & 1280 \\
\hline 0.50 & $\mathrm{SnPb}$ & LF35 & 215 & 2278 & 2280 & 3223 & 3223 & 1062 & 1063 & 1587 & 1819 \\
\hline 0.50 & $\mathrm{SnPb}$ & SAC105 & 220 & 8799 & 8800 & 8800 & n.f. & 1956 & 1956 & 1959 & 2027 \\
\hline 0.50 & $\mathrm{SnPb}$ & SAC105 & 220 & 8427 & 8427 & 8430 & n.f. & 2079 & 2079 & 2154 & 2363 \\
\hline 0.80 & $\mathrm{SnPb}$ & $\mathrm{SnPb}$ & 215 & 1025 & 1025 & 1100 & 1100 & 618 & 618 & 629 & 629 \\
\hline 0.80 & $\mathrm{SnPb}$ & $\mathrm{SnPb}$ & 215 & 1049 & 1050 & 1113 & 1113 & 637 & 638 & 647 & 647 \\
\hline 0.80 & $\mathrm{SnPb}$ & $\mathrm{SnPb}$ & 215 & 1128 & 1130 & 1211 & 1211 & 699 & 699 & 708 & 708 \\
\hline 0.80 & $\mathrm{SnPb}$ & $\mathrm{SnPb}$ & 215 & 1005 & 1005 & 1159 & 1159 & 609 & 609 & 627 & 627 \\
\hline 0.80 & $\mathrm{SnPb}$ & $\mathrm{SnPb}$ & 215 & 1172 & 1172 & 1194 & 1194 & 576 & 576 & 602 & 602 \\
\hline 0.80 & $\mathrm{SnPb}$ & $\mathrm{SnPb}$ & 215 & 1242 & 1242 & 1305 & 1305 & 542 & 542 & 575 & 575 \\
\hline 0.80 & $\mathrm{SnPb}$ & $\mathrm{SnPb}$ & 215 & 1085 & 1086 & 1114 & 1114 & 611 & 611 & 665 & 665 \\
\hline 0.80 & $\mathrm{SnPb}$ & $\mathrm{SnPb}$ & 215 & 1000 & 1000 & 1080 & 1080 & 593 & 594 & 595 & 595 \\
\hline 0.80 & $\mathrm{SnPb}$ & $\mathrm{SnPb}$ & 215 & 1055 & 1055 & 1251 & 1251 & 692 & 697 & 780 & 780 \\
\hline 0.80 & $\mathrm{SnPb}$ & $\mathrm{SnPb}$ & 215 & 888 & 888 & 966 & 966 & 646 & 646 & 665 & 665 \\
\hline 0.80 & $\mathrm{SnPb}$ & $\mathrm{SnPb}$ & 215 & 941 & 942 & 1065 & 1065 & 534 & 534 & 566 & 566 \\
\hline 0.80 & $\mathrm{SnPb}$ & $\mathrm{SnPb}$ & 215 & 1044 & 1058 & 1118 & 1118 & 711 & 711 & 780 & 780 \\
\hline 0.80 & $\mathrm{SnPb}$ & $\mathrm{SnPb}$ & 215 & 958 & 966 & 1015 & 1015 & 778 & 778 & 788 & 788 \\
\hline 0.80 & $\mathrm{SnPb}$ & $\mathrm{SnPb}$ & 215 & 1102 & 1102 & 1125 & 1125 & 688 & 687 & 761 & 761 \\
\hline 0.80 & $\mathrm{SnPb}$ & $\mathrm{SnPb}$ & 215 & 901 & 901 & 919 & 919 & 609 & 609 & 621 & 621 \\
\hline 0.80 & $\mathrm{SnPb}$ & $\mathrm{SnPb}$ & 215 & 1036 & 1036 & 1110 & 1110 & 608 & 608 & 618 & 618 \\
\hline 0.80 & $\mathrm{SnPb}$ & $\mathrm{SnPb}$ & 215 & 1061 & 1069 & 1159 & 1159 & 714 & 714 & 724 & 724 \\
\hline 0.80 & $\mathrm{SnPb}$ & $\mathrm{SnPb}$ & 215 & 950 & 950 & 1016 & 1016 & 463 & 463 & 476 & 476 \\
\hline 0.80 & $\mathrm{SnPb}$ & $\mathrm{SnPb}$ & 215 & 851 & 860 & 927 & 927 & 639 & 639 & 645 & 645 \\
\hline 0.80 & $\mathrm{SnPb}$ & $\mathrm{SnPb}$ & 215 & 926 & 927 & 1026 & 1026 & 610 & 610 & 624 & 624 \\
\hline 0.80 & $\mathrm{SnPb}$ & SAC305 & 215 & 2660 & 2664 & 3131 & 3131 & 530 & 530 & 856 & 856 \\
\hline 0.80 & $\mathrm{SnPb}$ & SAC305 & 215 & 1841 & 1842 & 2665 & 2665 & 959 & 959 & 1086 & 1086 \\
\hline 0.80 & $\mathrm{SnPb}$ & SAC305 & 215 & 2992 & 2993 & 3119 & 3119 & 1370 & 1370 & 1522 & 1649 \\
\hline 0.80 & $\mathrm{SnPb}$ & SAC305 & 215 & 2756 & 2759 & 3432 & 3497 & 746 & 746 & 905 & 905 \\
\hline 0.80 & $\mathrm{SnPb}$ & SAC305 & 215 & 2245 & 2245 & 3537 & 3632 & 887 & 887 & 1047 & 1047 \\
\hline 0.80 & $\mathrm{SnPb}$ & SAC305 & 215 & 3088 & 3088 & 3716 & 3716 & 1001 & 1009 & 1371 & 1371 \\
\hline 0.80 & $\mathrm{SnPb}$ & SAC305 & 215 & 2915 & 2922 & 3402 & 3402 & 571 & 571 & 643 & 643 \\
\hline
\end{tabular}




\begin{tabular}{|c|c|c|c|c|c|c|c|c|c|c|c|}
\hline \multicolumn{4}{|c|}{ Treatment } & \multicolumn{4}{|c|}{$0^{\circ} \mathrm{C}$ to $100{ }^{\circ} \mathrm{C}$ TCR } & \multicolumn{4}{|c|}{$-40{ }^{\circ} \mathrm{C}$ to $125^{\circ} \mathrm{C}$ TCR } \\
\hline $\begin{array}{l}\text { Pkg } \\
\text { Desc } \\
(\mathrm{mm})\end{array}$ & $\begin{array}{l}\text { Paste } \\
\text { Alloy }\end{array}$ & $\begin{array}{c}\text { Ball } \\
\text { Alloy }\end{array}$ & $\begin{array}{l}\text { PRT } \\
\left({ }^{\circ} \mathbf{C}\right)\end{array}$ & $\underset{\text { and } R}{\overline{\mathbf{X}}}$ & $\begin{array}{l}\text { IPC- } \\
\text { 9701A }\end{array}$ & $500 \Omega$ & $\begin{array}{l}\text { Inf. } \\
\text { Resist. }\end{array}$ & $\underset{\text { and } R}{\overline{\mathbf{X}}}$ & $\begin{array}{c}\text { IPC- } \\
\text { 9701A }\end{array}$ & $500 \Omega$ & $\begin{array}{c}\text { Inf. } \\
\text { Resist. }\end{array}$ \\
\hline 0.80 & $\mathrm{SnPb}$ & SAC305 & 215 & 1907 & 1912 & 1930 & 4291 & 1114 & 1115 & 1173 & 1173 \\
\hline 0.80 & $\mathrm{SnPb}$ & SAC305 & 215 & 3303 & 3303 & 3322 & 4423 & 1214 & 1221 & 1367 & 1367 \\
\hline 0.80 & $\mathrm{SnPb}$ & SAC305 & 215 & 2073 & 2076 & 3379 & 3379 & 1192 & 1192 & 1230 & 1230 \\
\hline 0.80 & $\mathrm{SnPb}$ & SAC305 & 215 & 2512 & 2515 & 3106 & 3106 & 989 & 996 & 1308 & 1308 \\
\hline 0.80 & $\mathrm{SnPb}$ & SAC305 & 215 & 2937 & 2938 & 3369 & 3369 & 1333 & 1333 & 1523 & 1523 \\
\hline 0.80 & $\mathrm{SnPb}$ & SAC305 & 215 & 1532 & 1534 & 2415 & 2415 & 955 & 955 & 1118 & 1272 \\
\hline 0.80 & $\mathrm{SnPb}$ & SAC305 & 215 & 2082 & 2082 & 3294 & 3294 & 1191 & 1194 & 1284 & 1284 \\
\hline 0.80 & $\mathrm{SnPb}$ & SAC305 & 215 & 3314 & 3314 & 3348 & 3348 & 651 & 651 & 949 & 949 \\
\hline 0.80 & $\mathrm{SnPb}$ & SAC305 & 215 & 2808 & 2808 & 3166 & 3166 & 1483 & 1483 & 1532 & 1532 \\
\hline 0.80 & $\mathrm{SnPb}$ & SAC305 & 215 & 3055 & 3055 & 3530 & 3530 & 952 & 952 & 1211 & 1211 \\
\hline 0.80 & $\mathrm{SnPb}$ & SAC305 & 215 & 2365 & 2371 & 2550 & 2550 & 1331 & 1331 & 1448 & 1448 \\
\hline 0.80 & $\mathrm{SnPb}$ & SAC305 & 215 & 2630 & 2630 & 2822 & 2822 & 878 & 878 & 1246 & 1246 \\
\hline 0.80 & $\mathrm{SnPb}$ & SAC305 & 215 & 3112 & 3113 & 3463 & 3463 & 784 & 787 & 1522 & 1522 \\
\hline 0.80 & $\mathrm{SnPb}$ & SAC105 & 215 & 1132 & 1132 & 1875 & 1875 & 708 & 708 & 718 & 718 \\
\hline 0.80 & $\mathrm{SnPb}$ & SAC105 & 215 & 1126 & 1127 & 1740 & 1740 & 688 & 688 & 708 & 708 \\
\hline 0.80 & $\mathrm{SnPb}$ & SAC105 & 215 & 1784 & 1784 & 2076 & 2076 & 821 & 821 & 831 & 831 \\
\hline 0.80 & $\mathrm{SnPb}$ & SAC105 & 215 & 1320 & 1323 & 1786 & 1786 & 330 & 333 & 403 & 403 \\
\hline 0.80 & $\mathrm{SnPb}$ & SAC105 & 215 & 1139 & 1148 & 1729 & 1729 & 481 & 481 & 513 & 513 \\
\hline 0.80 & $\mathrm{SnPb}$ & SAC105 & 215 & 1920 & 1920 & 1996 & 1996 & 641 & 641 & 670 & 670 \\
\hline 0.80 & $\mathrm{SnPb}$ & SAC105 & 215 & 1685 & 1690 & 2158 & 2158 & 657 & 657 & 941 & 941 \\
\hline 0.80 & $\mathrm{SnPb}$ & SAC105 & 215 & 1824 & 1824 & 2138 & 2138 & 370 & 370 & 546 & 754 \\
\hline 0.80 & $\mathrm{SnPb}$ & SAC105 & 215 & 2232 & 2232 & 2315 & 2315 & 902 & 902 & 967 & 967 \\
\hline 0.80 & $\mathrm{SnPb}$ & SAC105 & 215 & 1475 & 1479 & 1733 & 1733 & 567 & 567 & 676 & 676 \\
\hline 0.80 & $\mathrm{SnPb}$ & SAC105 & 215 & 1803 & 1804 & 1854 & 1854 & 671 & 673 & 725 & 725 \\
\hline 0.80 & $\mathrm{SnPb}$ & SAC105 & 215 & 2010 & 2010 & 2180 & 2180 & 852 & 852 & 872 & 872 \\
\hline 0.80 & $\mathrm{SnPb}$ & SAC105 & 215 & 1332 & 1332 & 1806 & 1806 & 222 & 222 & 636 & 636 \\
\hline 0.80 & $\mathrm{SnPb}$ & SAC105 & 215 & 2267 & 2267 & 2421 & 2421 & 800 & 802 & 838 & 838 \\
\hline 0.80 & $\mathrm{SnPb}$ & SAC105 & 215 & 1381 & 1382 & 1705 & 1705 & 524 & 524 & 622 & 622 \\
\hline 0.80 & $\mathrm{SnPb}$ & SAC105 & 215 & 1508 & 1511 & 2052 & 2052 & 472 & 476 & 754 & 754 \\
\hline 0.80 & $\mathrm{SnPb}$ & SAC105 & 215 & 1922 & 1922 & 2220 & 2220 & 998 & 998 & 1004 & 1004 \\
\hline 0.80 & $\mathrm{SnPb}$ & SAC105 & 215 & 851 & 851 & 1490 & 1490 & 362 & 362 & 563 & 563 \\
\hline 0.80 & $\mathrm{SnPb}$ & SAC105 & 215 & 1311 & 1311 & 1606 & 1606 & 625 & 625 & 705 & 705 \\
\hline 0.80 & $\mathrm{SnPb}$ & SAC105 & 215 & 1929 & 1929 & 2079 & 2079 & 824 & 824 & 868 & 868 \\
\hline 0.80 & $\mathrm{SnPb}$ & SACX & 215 & 957 & 957 & 1502 & 1502 & 406 & 407 & 742 & 742 \\
\hline 0.80 & $\mathrm{SnPb}$ & SACX & 215 & 1398 & 1400 & 2101 & 2101 & 543 & 543 & 793 & 793 \\
\hline 0.80 & $\mathrm{SnPb}$ & SACX & 215 & 2233 & 2233 & 2693 & 2693 & 532 & 535 & 877 & 877 \\
\hline
\end{tabular}




\begin{tabular}{|c|c|c|c|c|c|c|c|c|c|c|c|}
\hline \multicolumn{4}{|c|}{ Treatment } & \multicolumn{4}{|c|}{$0^{\circ} \mathrm{C}$ to $100^{\circ} \mathrm{C}$ TCR } & \multicolumn{4}{|c|}{$-40{ }^{\circ} \mathrm{C}$ to $125^{\circ} \mathrm{C}$ TCR } \\
\hline $\begin{array}{l}\text { Pkg } \\
\text { Desc } \\
(\mathrm{mm})\end{array}$ & $\begin{array}{l}\text { Paste } \\
\text { Alloy }\end{array}$ & $\begin{array}{l}\text { Ball } \\
\text { Alloy }\end{array}$ & $\begin{array}{l}\text { PRT } \\
\left({ }^{\circ} \mathbf{C}\right)\end{array}$ & $\underset{\text { and } R}{\overline{\mathbf{X}}}$ & $\begin{array}{l}\text { IPC- } \\
9701 \mathrm{~A}\end{array}$ & $500 \Omega$ & $\begin{array}{l}\text { Inf. } \\
\text { Resist. }\end{array}$ & $\underset{\text { and } R}{\overline{\mathbf{X}}}$ & $\begin{array}{l}\text { IPC- } \\
9701 \mathrm{~A}\end{array}$ & $500 \Omega$ & $\begin{array}{c}\text { Inf. } \\
\text { Resist. }\end{array}$ \\
\hline 0.80 & $\mathrm{SnPb}$ & SACX & 215 & 1366 & 1366 & 2466 & 2466 & 546 & 546 & 839 & 839 \\
\hline 0.80 & $\mathrm{SnPb}$ & SACX & 215 & 915 & 915 & 1544 & 1544 & 535 & 535 & 817 & 817 \\
\hline 0.80 & $\mathrm{SnPb}$ & SACX & 215 & 2848 & 2848 & 2933 & 2933 & 832 & 832 & 929 & 933 \\
\hline 0.80 & $\mathrm{SnPb}$ & SACX & 215 & 1381 & 1383 & 2447 & 2447 & 519 & 520 & 813 & 813 \\
\hline 0.80 & $\mathrm{SnPb}$ & SACX & 215 & 808 & 809 & 1500 & 1500 & 810 & 810 & 909 & 909 \\
\hline 0.80 & $\mathrm{SnPb}$ & SACX & 215 & 2255 & 2255 & 2819 & 2819 & 1182 & 1182 & 1350 & 1350 \\
\hline 0.80 & $\mathrm{SnPb}$ & SACX & 215 & 882 & 882 & 1233 & 1233 & 256 & 255 & 428 & 428 \\
\hline 0.80 & $\mathrm{SnPb}$ & SACX & 215 & 871 & 872 & 1593 & 1593 & 762 & 766 & 866 & 866 \\
\hline 0.80 & $\mathrm{SnPb}$ & SACX & 215 & 1862 & 1862 & 2408 & 2408 & 886 & 887 & 920 & 920 \\
\hline 0.80 & $\mathrm{SnPb}$ & SACX & 215 & 1311 & 1314 & 2120 & 2120 & 762 & 762 & 1081 & 1081 \\
\hline 0.80 & $\mathrm{SnPb}$ & SACX & 215 & 1970 & 1970 & 2393 & 2393 & 1248 & 1248 & 1396 & 1396 \\
\hline 0.80 & $\mathrm{SnPb}$ & SACX & 215 & 777 & 782 & 1876 & 1876 & 372 & 372 & 474 & 474 \\
\hline 0.80 & $\mathrm{SnPb}$ & SACX & 215 & 789 & 831 & 1765 & 1765 & 436 & 436 & 732 & 732 \\
\hline 0.80 & $\mathrm{SnPb}$ & SACX & 215 & 1940 & 1943 & 2680 & 2680 & 998 & 999 & 1232 & 1232 \\
\hline 0.80 & $\mathrm{SnPb}$ & SACX & 215 & 873 & 873 & 1577 & 1577 & 493 & 493 & 898 & 898 \\
\hline 0.80 & $\mathrm{SnPb}$ & SACX & 215 & 953 & 953 & 1813 & 1813 & 372 & 374 & 791 & 791 \\
\hline 0.80 & $\mathrm{SnPb}$ & SACX & 215 & 1920 & 1924 & 2897 & 2897 & 692 & 692 & 1113 & 1113 \\
\hline 0.80 & $\mathrm{SnPb}$ & LF35 & 215 & 3334 & 3337 & 4281 & 4443 & 1062 & 1066 & 1645 & 1781 \\
\hline 0.80 & $\mathrm{SnPb}$ & SAC105 & 220 & 4203 & 4203 & 4442 & 4442 & 2052 & 2052 & 2133 & 2147 \\
\hline 0.80 & $\mathrm{SnPb}$ & SAC105 & 220 & 3495 & 3495 & 4302 & 4306 & 1585 & 1585 & 1638 & 1638 \\
\hline 1.00 & $\mathrm{SnPb}$ & $\mathrm{SnPb}$ & 215 & 2806 & 2809 & 2960 & 3036 & 1232 & 1233 & 1248 & 1248 \\
\hline 1.00 & $\mathrm{SnPb}$ & $\mathrm{SnPb}$ & 215 & 2088 & 2090 & 2747 & 2747 & 1313 & 1313 & 1336 & 1336 \\
\hline 1.00 & $\mathrm{SnPb}$ & $\mathrm{SnPb}$ & 215 & 1388 & 1389 & 1390 & 1390 & 1388 & 1389 & 1390 & 1390 \\
\hline 1.00 & $\mathrm{SnPb}$ & $\mathrm{SnPb}$ & 215 & 1690 & 1690 & 1866 & 1866 & 1258 & 1258 & 1270 & 1281 \\
\hline 1.00 & $\mathrm{SnPb}$ & $\mathrm{SnPb}$ & 215 & 2705 & 2706 & 2810 & 2810 & 1339 & 1340 & 1372 & 1372 \\
\hline 1.00 & $\mathrm{SnPb}$ & $\mathrm{SnPb}$ & 215 & 2480 & 2480 & 2765 & 2765 & 1440 & 1440 & 1644 & 1644 \\
\hline 1.00 & $\mathrm{SnPb}$ & $\mathrm{SnPb}$ & 215 & 2210 & 2210 & 2300 & 2300 & 1366 & 1366 & 1379 & 1391 \\
\hline 1.00 & $\mathrm{SnPb}$ & $\mathrm{SnPb}$ & 215 & 1801 & 1801 & 2020 & 2020 & 1299 & 1300 & 1322 & 1322 \\
\hline 1.00 & $\mathrm{SnPb}$ & $\mathrm{SnPb}$ & 215 & 1882 & 1887 & 2098 & 2098 & 1328 & 1328 & 1356 & 1356 \\
\hline 1.00 & $\mathrm{SnPb}$ & $\mathrm{SnPb}$ & 215 & 1812 & 1812 & 1962 & 1962 & 1261 & 1261 & 1264 & 1264 \\
\hline 1.00 & $\mathrm{SnPb}$ & $\mathrm{SnPb}$ & 215 & 2225 & 2226 & 2269 & 2269 & 1469 & 1479 & 1561 & 1561 \\
\hline 1.00 & $\mathrm{SnPb}$ & $\mathrm{SnPb}$ & 215 & 1753 & 1753 & 2015 & 2015 & 1090 & 1090 & 1198 & 1198 \\
\hline 1.00 & $\mathrm{SnPb}$ & $\mathrm{SnPb}$ & 215 & 1840 & 1842 & 2077 & 2077 & 1605 & 1605 & 1663 & 1663 \\
\hline 1.00 & $\mathrm{SnPb}$ & $\mathrm{SnPb}$ & 215 & 1980 & 1985 & 2172 & 2172 & 1538 & 1540 & 1622 & 1622 \\
\hline 1.00 & $\mathrm{SnPb}$ & $\mathrm{SnPb}$ & 215 & 2102 & 2102 & 2126 & 2260 & 1420 & 1425 & 1459 & 1459 \\
\hline 1.00 & $\mathrm{SnPb}$ & $\mathrm{SnPb}$ & 215 & 1975 & 1975 & 2439 & 2439 & 1396 & 1396 & 1485 & 1485 \\
\hline
\end{tabular}




\begin{tabular}{|c|c|c|c|c|c|c|c|c|c|c|c|}
\hline \multicolumn{4}{|c|}{ Treatment } & \multicolumn{4}{|c|}{$0^{\circ} \mathrm{C}$ to $100{ }^{\circ} \mathrm{C}$ TCR } & \multicolumn{4}{|c|}{$-40{ }^{\circ} \mathrm{C}$ to $125^{\circ} \mathrm{C}$ TCR } \\
\hline $\begin{array}{l}\text { Pkg } \\
\text { Desc } \\
(\mathrm{mm})\end{array}$ & $\begin{array}{l}\text { Paste } \\
\text { Alloy }\end{array}$ & $\begin{array}{c}\text { Ball } \\
\text { Alloy }\end{array}$ & $\begin{array}{l}\text { PRT } \\
\left({ }^{\circ} \mathbf{C}\right)\end{array}$ & $\underset{\text { and } R}{\overline{\mathbf{X}}}$ & $\begin{array}{l}\text { IPC- } \\
\text { 9701A }\end{array}$ & $500 \Omega$ & $\begin{array}{l}\text { Inf. } \\
\text { Resist. }\end{array}$ & $\underset{\text { and } R}{\overline{\mathbf{X}}}$ & $\begin{array}{c}\text { IPC- } \\
\text { 9701A }\end{array}$ & $500 \Omega$ & $\begin{array}{c}\text { Inf. } \\
\text { Resist. }\end{array}$ \\
\hline 1.00 & $\mathrm{SnPb}$ & $\mathrm{SnPb}$ & 215 & 1639 & 1640 & 1818 & 1818 & 974 & 981 & 1442 & 1442 \\
\hline 1.00 & $\mathrm{SnPb}$ & $\mathrm{SnPb}$ & 215 & 2125 & 2125 & 2161 & 2292 & 1307 & 1307 & 1315 & 1315 \\
\hline 1.00 & $\mathrm{SnPb}$ & $\mathrm{SnPb}$ & 215 & 1936 & 1968 & 2292 & 2292 & 1353 & 1353 & 1379 & 1379 \\
\hline 1.00 & $\mathrm{SnPb}$ & $\mathrm{SnPb}$ & 215 & 1871 & 1871 & 2152 & 2152 & 1050 & 1051 & 1123 & 1123 \\
\hline 1.00 & $\mathrm{SnPb}$ & SAC305 & 215 & 6747 & 6747 & 6748 & 7101 & 2266 & 2266 & 2349 & 2622 \\
\hline 1.00 & $\mathrm{SnPb}$ & SAC305 & 215 & 5672 & 5672 & 6409 & 6409 & 2502 & 2502 & 2808 & 2808 \\
\hline 1.00 & $\mathrm{SnPb}$ & SAC305 & 215 & 6033 & 6037 & 6624 & 6742 & 2857 & 2857 & 3074 & 3074 \\
\hline 1.00 & $\mathrm{SnPb}$ & SAC305 & 215 & 8232 & 8232 & 8233 & 8709 & 1368 & 1368 & 1410 & 1423 \\
\hline 1.00 & $\mathrm{SnPb}$ & SAC305 & 215 & 7770 & 7771 & 9085 & 9166 & 1932 & 1934 & 2021 & 2021 \\
\hline 1.00 & $\mathrm{SnPb}$ & SAC305 & 215 & 6635 & 6636 & 7307 & 7895 & 2122 & 2122 & 2174 & 2174 \\
\hline 1.00 & $\mathrm{SnPb}$ & SAC305 & 215 & 6673 & 6675 & 6780 & 8991 & 2435 & 2435 & 2442 & 2447 \\
\hline 1.00 & $\mathrm{SnPb}$ & SAC305 & 215 & 6793 & 6793 & 7853 & 8488 & 2181 & 2181 & 2270 & 2270 \\
\hline 1.00 & $\mathrm{SnPb}$ & SAC305 & 215 & 4495 & 4495 & 4518 & 6045 & 1606 & 1606 & 1628 & 1628 \\
\hline 1.00 & $\mathrm{SnPb}$ & SAC305 & 215 & 5754 & 5754 & 5798 & 5886 & 2480 & 2480 & 2521 & 2524 \\
\hline 1.00 & $\mathrm{SnPb}$ & SAC305 & 215 & 5539 & 5540 & 6533 & 6533 & 2583 & 2587 & 2657 & 2657 \\
\hline 1.00 & $\mathrm{SnPb}$ & SAC305 & 215 & 4872 & 4872 & 5581 & 5581 & 2202 & 2202 & 2447 & 2447 \\
\hline 1.00 & $\mathrm{SnPb}$ & SAC305 & 215 & 4545 & 4545 & 5108 & 5147 & 2252 & 2252 & 2316 & 2316 \\
\hline 1.00 & $\mathrm{SnPb}$ & SAC305 & 215 & 4543 & 4543 & 4888 & 4888 & 2186 & 2186 & 2213 & 2213 \\
\hline 1.00 & $\mathrm{SnPb}$ & SAC305 & 215 & 5920 & 5920 & 6323 & 7773 & 2598 & 2598 & 2623 & 2917 \\
\hline 1.00 & $\mathrm{SnPb}$ & SAC305 & 215 & 2706 & 2708 & 3368 & 3368 & 2466 & 2467 & 2814 & 2814 \\
\hline 1.00 & $\mathrm{SnPb}$ & SAC305 & 215 & 5649 & 5649 & 6492 & 6553 & 2348 & 2348 & 2455 & 2455 \\
\hline 1.00 & $\mathrm{SnPb}$ & SAC305 & 215 & 7853 & 7853 & 8124 & 8874 & 2779 & 2779 & 2849 & 2858 \\
\hline 1.00 & $\mathrm{SnPb}$ & SAC305 & 215 & 7165 & 7165 & 7836 & 8293 & 2293 & 2293 & 2497 & 2506 \\
\hline 1.00 & $\mathrm{SnPb}$ & SAC305 & 215 & 5927 & 5927 & 6446 & 6446 & 2196 & 2196 & 2359 & 2359 \\
\hline 1.00 & $\mathrm{SnPb}$ & SAC105 & 215 & 5375 & 5375 & 5456 & 5504 & 1710 & 1710 & 1714 & 2056 \\
\hline 1.00 & $\mathrm{SnPb}$ & SAC105 & 215 & 4849 & 4849 & 5147 & 5147 & 1825 & 1825 & 1897 & 1898 \\
\hline 1.00 & $\mathrm{SnPb}$ & SAC105 & 215 & 4088 & 4089 & 4648 & 4648 & 1511 & 1511 & 1518 & 1857 \\
\hline 1.00 & $\mathrm{SnPb}$ & SAC105 & 215 & 5573 & 5573 & 5626 & 6113 & 1896 & 1896 & 1901 & 2043 \\
\hline 1.00 & $\mathrm{SnPb}$ & SAC105 & 215 & 3394 & 3396 & 3784 & 4041 & 1638 & 1644 & 1711 & 1854 \\
\hline 1.00 & $\mathrm{SnPb}$ & SAC105 & 215 & 3885 & 3885 & 4407 & 4423 & 1506 & 1506 & 1509 & 1521 \\
\hline 1.00 & $\mathrm{SnPb}$ & SAC105 & 215 & 5839 & 5839 & 5993 & 6415 & 1809 & 1811 & 1854 & 1964 \\
\hline 1.00 & $\mathrm{SnPb}$ & SAC105 & 215 & 5179 & 5180 & 5471 & 6087 & 1625 & 1625 & 1682 & 2218 \\
\hline 1.00 & $\mathrm{SnPb}$ & SAC105 & 215 & 4489 & 4489 & 4705 & 4705 & 1614 & 1614 & 1619 & 1620 \\
\hline 1.00 & $\mathrm{SnPb}$ & SAC105 & 215 & 3883 & 3883 & 3891 & 4059 & 2137 & 2138 & 2150 & 2185 \\
\hline 1.00 & $\mathrm{SnPb}$ & SAC105 & 215 & 4279 & 4283 & 4553 & 4913 & 2180 & 2180 & 2195 & 2195 \\
\hline 1.00 & $\mathrm{SnPb}$ & SAC105 & 215 & 4870 & 4870 & 4940 & 4940 & 1881 & 1881 & 1922 & 1971 \\
\hline
\end{tabular}




\begin{tabular}{|c|c|c|c|c|c|c|c|c|c|c|c|}
\hline \multicolumn{4}{|c|}{ Treatment } & \multicolumn{4}{|c|}{$0^{\circ} \mathrm{C}$ to $100{ }^{\circ} \mathrm{C}$ TCR } & \multicolumn{4}{|c|}{$-40{ }^{\circ} \mathrm{C}$ to $125^{\circ} \mathrm{C}$ TCR } \\
\hline $\begin{array}{l}\text { Pkg } \\
\text { Desc } \\
(\mathrm{mm})\end{array}$ & $\begin{array}{l}\text { Paste } \\
\text { Alloy }\end{array}$ & $\begin{array}{c}\text { Ball } \\
\text { Alloy }\end{array}$ & $\begin{array}{l}\text { PRT } \\
\left({ }^{\circ} \mathbf{C}\right)\end{array}$ & $\underset{\text { and } R}{\overline{\mathbf{X}}}$ & $\begin{array}{l}\text { IPC- } \\
\text { 9701A }\end{array}$ & $500 \Omega$ & $\begin{array}{l}\text { Inf. } \\
\text { Resist. }\end{array}$ & $\underset{\text { and } R}{\overline{\mathbf{X}}}$ & $\begin{array}{c}\text { IPC- } \\
\text { 9701A }\end{array}$ & $500 \Omega$ & $\begin{array}{c}\text { Inf. } \\
\text { Resist. }\end{array}$ \\
\hline 1.00 & $\mathrm{SnPb}$ & SAC105 & 215 & 4231 & 4231 & 4605 & 4605 & 1017 & 1017 & 1261 & 1409 \\
\hline 1.00 & $\mathrm{SnPb}$ & SAC105 & 215 & 3266 & 3266 & 3494 & 3494 & 1783 & 1783 & 1783 & 1783 \\
\hline 1.00 & $\mathrm{SnPb}$ & SAC105 & 215 & 5574 & 5574 & 5606 & 6122 & 1504 & 1504 & 1514 & 1789 \\
\hline 1.00 & $\mathrm{SnPb}$ & SAC105 & 215 & 5243 & 5243 & 5692 & 5692 & 1608 & 1608 & 1620 & 1620 \\
\hline 1.00 & $\mathrm{SnPb}$ & SAC105 & 215 & 4778 & 4778 & 4997 & 4997 & 1783 & 1783 & 1870 & 1996 \\
\hline 1.00 & $\mathrm{SnPb}$ & SAC105 & 215 & 4356 & 4356 & 4389 & 4893 & 1986 & 1986 & 1989 & 2041 \\
\hline 1.00 & $\mathrm{SnPb}$ & SAC105 & 215 & 3741 & 3744 & 4702 & 4719 & 1997 & 1997 & 2084 & 2143 \\
\hline 1.00 & $\mathrm{SnPb}$ & SAC105 & 215 & 3895 & 3895 & 4431 & 4431 & 1684 & 1688 & 1769 & 1810 \\
\hline 1.00 & $\mathrm{SnPb}$ & SACX & 215 & 3310 & 3310 & 3353 & 3379 & 1877 & 1886 & 1947 & 1949 \\
\hline 1.00 & $\mathrm{SnPb}$ & SACX & 215 & 2635 & 2635 & 2781 & 2787 & 2323 & 2323 & 2344 & 2344 \\
\hline 1.00 & $\mathrm{SnPb}$ & SACX & 215 & 3847 & 3847 & 3855 & 3855 & 1878 & 1878 & 1918 & 1975 \\
\hline 1.00 & $\mathrm{SnPb}$ & SACX & 215 & 3903 & 3903 & 3912 & 4785 & 1757 & 1757 & 1784 & 1968 \\
\hline 1.00 & $\mathrm{SnPb}$ & SACX & 215 & 4494 & 4495 & 4800 & 4831 & 2067 & 2067 & 2096 & 2129 \\
\hline 1.00 & $\mathrm{SnPb}$ & SACX & 215 & 4208 & 4209 & 4938 & 5067 & 1858 & 1858 & 1871 & 1904 \\
\hline 1.00 & $\mathrm{SnPb}$ & SACX & 215 & 3880 & 3881 & 3883 & 3928 & 1719 & 1719 & 1720 & 1911 \\
\hline 1.00 & $\mathrm{SnPb}$ & SACX & 215 & 3470 & 3470 & 4083 & 4083 & 2040 & 2043 & 2187 & 2223 \\
\hline 1.00 & $\mathrm{SnPb}$ & SACX & 215 & 3390 & 3391 & 3842 & 3842 & 1985 & 1985 & 2050 & 2094 \\
\hline 1.00 & $\mathrm{SnPb}$ & SACX & 215 & 2387 & 2387 & 2586 & 3043 & 1735 & 1735 & 1744 & 1766 \\
\hline 1.00 & $\mathrm{SnPb}$ & SACX & 215 & 2635 & 2640 & 2993 & 3028 & 1723 & 1724 & 1856 & 1891 \\
\hline 1.00 & $\mathrm{SnPb}$ & SACX & 215 & 16 & 16 & 16 & 16 & 1373 & 1374 & 1394 & 1394 \\
\hline 1.00 & $\mathrm{SnPb}$ & SACX & 215 & 4361 & 4361 & 4529 & 4577 & 1459 & 1460 & 1609 & 1609 \\
\hline 1.00 & $\mathrm{SnPb}$ & SACX & 215 & 3604 & 3605 & 3675 & 3675 & 1642 & 1643 & 1707 & 1707 \\
\hline 1.00 & $\mathrm{SnPb}$ & SACX & 215 & 3684 & 3694 & 3838 & 4030 & 1633 & 1633 & 1644 & 1685 \\
\hline 1.00 & $\mathrm{SnPb}$ & SACX & 215 & 3850 & 3850 & 4090 & 4351 & 1379 & 1379 & 1474 & 1474 \\
\hline 1.00 & $\mathrm{SnPb}$ & SACX & 215 & 3726 & 3726 & 3733 & 4006 & 1588 & 1588 & 1619 & 1619 \\
\hline 1.00 & $\mathrm{SnPb}$ & SACX & 215 & 3796 & 3796 & 3834 & 4059 & 1430 & 1430 & 1440 & 1485 \\
\hline 1.00 & $\mathrm{SnPb}$ & SACX & 215 & 3659 & 3659 & 4587 & 4587 & 2019 & 2020 & 2071 & 2071 \\
\hline 1.00 & $\mathrm{SnPb}$ & SACX & 215 & 3219 & 3219 & 4167 & 4227 & 1349 & 1349 & 1431 & 1431 \\
\hline 1.00 & $\mathrm{SnPb}$ & LF35 & 215 & 3476 & 3480 & 4193 & 4193 & 1402 & 1402 & 1815 & 2067 \\
\hline 1.00 & $\mathrm{SnPb}$ & LF35 & 215 & 3430 & 3434 & 4768 & 4873 & 2026 & 2045 & 2167 & 2301 \\
\hline 1.00 & $\mathrm{SnPb}$ & SAC105 & 220 & 4827 & 4827 & 5023 & 5023 & 2425 & 2431 & 2634 & 2640 \\
\hline 1.00 & $\mathrm{SnPb}$ & SAC105 & 220 & 5429 & 5442 & 5704 & 5985 & 2209 & 2209 & 2221 & 2352 \\
\hline 1.00 & $\mathrm{SnPb}$ & SAC105 & 220 & 4290 & 4293 & 5180 & 5180 & 1891 & 1891 & 1891 & 1891 \\
\hline 1.00 & $\mathrm{SnPb}$ & SAC105 & 220 & 5652 & 5658 & 6452 & 6452 & 2059 & 2059 & 2167 & 2167 \\
\hline 1.00 & $\mathrm{SnPb}$ & SAC105 & 220 & 5347 & 5348 & 6229 & 6229 & 1686 & 1686 & 2274 & 2278 \\
\hline 1.00 & $\mathrm{SnPb}$ & SAC105 & 220 & 4648 & 4648 & 5334 & 5432 & 1732 & 1733 & 1745 & 1757 \\
\hline
\end{tabular}




\begin{tabular}{|c|c|c|c|c|c|c|c|c|c|c|c|}
\hline \multicolumn{4}{|c|}{ Treatment } & \multicolumn{4}{|c|}{$0^{\circ} \mathrm{C}$ to $100^{\circ} \mathrm{C}$ TCR } & \multicolumn{4}{|c|}{$-40{ }^{\circ} \mathrm{C}$ to $125^{\circ} \mathrm{C}$ TCR } \\
\hline $\begin{array}{l}\text { Pkg } \\
\text { Desc } \\
(\mathrm{mm})\end{array}$ & $\begin{array}{l}\text { Paste } \\
\text { Alloy }\end{array}$ & $\begin{array}{l}\text { Ball } \\
\text { Alloy }\end{array}$ & $\begin{array}{l}\text { PRT } \\
\left({ }^{\circ} \mathrm{C}\right)\end{array}$ & $\underset{\text { and } R}{\overline{\mathbf{X}}}$ & $\begin{array}{c}\text { IPC- } \\
9701 A\end{array}$ & $500 \Omega$ & $\begin{array}{l}\text { Inf. } \\
\text { Resist. }\end{array}$ & $\underset{\text { and } R}{\overline{\mathbf{X}}}$ & $\begin{array}{c}\text { IPC- } \\
9701 \mathrm{~A}\end{array}$ & $500 \Omega$ & $\begin{array}{l}\text { Inf. } \\
\text { Resist. }\end{array}$ \\
\hline 1.00 & $\mathrm{SnPb}$ & SAC105 & 220 & 3013 & 3023 & 3191 & 3191 & 1979 & 1979 & 2006 & 2164 \\
\hline 1.00 & $\mathrm{SnPb}$ & SAC105 & 220 & 4942 & 4942 & 5875 & 5875 & 1987 & 1987 & 2075 & 2075 \\
\hline 1.00 & $\mathrm{SnPb}$ & SAC105 & 220 & 4119 & 4122 & 4857 & 4857 & 2513 & 2513 & 2514 & 2802 \\
\hline 1.00 & $\mathrm{SnPb}$ & SAC105 & 220 & 3298 & 3300 & 4237 & 4237 & 1904 & 1904 & 1958 & 1965 \\
\hline 1.00 & $\mathrm{SnPb}$ & SAC105 & 220 & 4085 & 4086 & 5223 & 5223 & 1869 & 1869 & 1881 & 1961 \\
\hline 1.00 & $\mathrm{SnPb}$ & SAC105 & 220 & 3982 & 3986 & 4620 & 4620 & 1529 & 1530 & 1538 & 1567 \\
\hline 1.00 & $\mathrm{SnPb}$ & SAC105 & 220 & 4482 & 4482 & 5448 & 5452 & 1844 & 1844 & 1873 & 1873 \\
\hline 1.00 & $\mathrm{SnPb}$ & SAC105 & 220 & 4054 & 4054 & 4704 & 4704 & 1793 & 1793 & 1829 & 1829 \\
\hline 1.00 & $\mathrm{SnPb}$ & SAC105 & 220 & 3827 & 3827 & 4287 & 4599 & 2094 & 2094 & 2115 & 2115 \\
\hline 1.00 & $\mathrm{SnPb}$ & SAC105 & 220 & 4395 & 4398 & 5499 & 5502 & 2197 & 2197 & 2233 & 2233 \\
\hline 1.00 & $\mathrm{SnPb}$ & SAC105 & 220 & 3328 & 3329 & 4473 & 4473 & 1655 & 1656 & 2027 & 2027 \\
\hline 1.00 & $\mathrm{SnPb}$ & SAC105 & 220 & 4471 & 4471 & 4264 & 5428 & 1909 & 1910 & 1991 & 2034 \\
\hline 1.27 & $\mathrm{SnPb}$ & $\mathrm{SnPb}$ & 215 & 5396 & 5396 & 5558 & 5558 & 1722 & 1722 & 1825 & 1825 \\
\hline 1.27 & $\mathrm{SnPb}$ & $\mathrm{SnPb}$ & 215 & 2136 & 2138 & 3463 & 2463 & 1379 & 1380 & 1388 & 1388 \\
\hline 1.27 & $\mathrm{SnPb}$ & $\mathrm{SnPb}$ & 215 & 3173 & 3175 & 3175 & 3530 & 1168 & 1168 & 1190 & 1229 \\
\hline 1.27 & $\mathrm{SnPb}$ & $\mathrm{SnPb}$ & 215 & 3127 & 3131 & 4312 & 4312 & 2790 & 2790 & 2792 & 2811 \\
\hline 1.27 & $\mathrm{SnPb}$ & $\mathrm{SnPb}$ & 215 & 2801 & 2801 & 2824 & 2855 & 2021 & 2021 & 2021 & 2022 \\
\hline 1.27 & $\mathrm{SnPb}$ & $\mathrm{SnPb}$ & 215 & 2757 & 2758 & 2952 & 3455 & 1944 & 1944 & 1949 & 1954 \\
\hline 1.27 & $\mathrm{SnPb}$ & $\mathrm{SnPb}$ & 215 & 2217 & 2217 & 2725 & 2725 & 2500 & 2499 & 2500 & 2565 \\
\hline 1.27 & $\mathrm{SnPb}$ & $\mathrm{SnPb}$ & 215 & 2504 & 2504 & 2616 & 2616 & 1809 & 1809 & 1820 & 1823 \\
\hline 1.27 & $\mathrm{SnPb}$ & $\mathrm{SnPb}$ & 215 & 5612 & 5628 & 5802 & 6310 & 1807 & 1807 & 1812 & 1837 \\
\hline 1.27 & $\mathrm{SnPb}$ & $\mathrm{SnPb}$ & 215 & 3953 & 3953 & 3962 & 3964 & 3374 & 3374 & 3394 & 3394 \\
\hline 1.27 & $\mathrm{SnPb}$ & $\mathrm{SnPb}$ & 215 & 2337 & 2337 & 2371 & 2538 & 1405 & 1405 & 1407 & 1462 \\
\hline 1.27 & $\mathrm{SnPb}$ & $\mathrm{SnPb}$ & 215 & 4544 & 4567 & 4571 & 5035 & 1398 & 1397 & 1403 & 1405 \\
\hline 1.27 & $\mathrm{SnPb}$ & $\mathrm{SnPb}$ & 215 & 2949 & 2949 & 3007 & 3007 & 1672 & 1672 & 1696 & 1696 \\
\hline 1.27 & $\mathrm{SnPb}$ & $\mathrm{SnPb}$ & 215 & 4612 & 4612 & 4722 & 4904 & 1488 & 1488 & 1511 & 1511 \\
\hline 1.27 & $\mathrm{SnPb}$ & $\mathrm{SnPb}$ & 215 & 4872 & 4879 & 5138 & 5138 & 1734 & 1734 & 1782 & 1785 \\
\hline 1.27 & $\mathrm{SnPb}$ & $\mathrm{SnPb}$ & 215 & 2600 & 2599 & 2607 & 2649 & 1752 & 1752 & 1754 & 1826 \\
\hline 1.27 & $\mathrm{SnPb}$ & $\mathrm{SnPb}$ & 215 & 2879 & 2879 & 2882 & 2980 & 1315 & 1315 & 1317 & 1317 \\
\hline 1.27 & $\mathrm{SnPb}$ & $\mathrm{SnPb}$ & 215 & 3135 & 3136 & 3521 & 3521 & 2036 & 2036 & 2177 & 2195 \\
\hline 1.27 & $\mathrm{SnPb}$ & $\mathrm{SnPb}$ & 215 & 2403 & 2403 & 2974 & 2974 & 1568 & 1568 & 1577 & 1612 \\
\hline 1.27 & $\mathrm{SnPb}$ & $\mathrm{SnPb}$ & 215 & 3163 & 3184 & 3272 & 3326 & 2345 & 2346 & 2353 & 2370 \\
\hline 1.27 & $\mathrm{SnPb}$ & SAC305 & 215 & n.f. & n.f. & n.f. & n.f. & 3388 & 3389 & 3409 & 3522 \\
\hline 1.27 & $\mathrm{SnPb}$ & SAC305 & 215 & 9879 & 9879 & 9881 & n.f. & 2906 & 2906 & 2914 & 2925 \\
\hline 1.27 & $\mathrm{SnPb}$ & SAC305 & 215 & n.f. & n.f. & n.f. & n.f. & n.f. & n.f. & n.f. & n.f. \\
\hline 1.27 & $\mathrm{SnPb}$ & SAC305 & 215 & 9748 & 9748 & 9767 & n.f. & n.f. & n.f. & n.f. & n.f. \\
\hline
\end{tabular}




\begin{tabular}{|c|c|c|c|c|c|c|c|c|c|c|c|}
\hline \multicolumn{4}{|c|}{ Treatment } & \multicolumn{4}{|c|}{$0^{\circ} \mathrm{C}$ to $100^{\circ} \mathrm{C}$ TCR } & \multicolumn{4}{|c|}{$-40{ }^{\circ} \mathrm{C}$ to $125^{\circ} \mathrm{C}$ TCR } \\
\hline $\begin{array}{c}\text { Pkg } \\
\text { Desc } \\
(\mathrm{mm})\end{array}$ & $\begin{array}{l}\text { Paste } \\
\text { Alloy }\end{array}$ & $\begin{array}{c}\text { Ball } \\
\text { Alloy }\end{array}$ & $\begin{array}{l}\text { PRT } \\
\left({ }^{\circ} \mathrm{C}\right)\end{array}$ & $\underset{\text { and } R}{\bar{X}}$ & $\begin{array}{c}\text { IPC- } \\
\text { 9701A }\end{array}$ & $500 \Omega$ & $\begin{array}{l}\text { Inf. } \\
\text { Resist. }\end{array}$ & $\underset{\text { and } R}{\overline{\mathbf{X}}}$ & $\begin{array}{c}\text { IPC- } \\
\text { 9701A }\end{array}$ & $500 \Omega$ & $\begin{array}{l}\text { Inf. } \\
\text { Resist. }\end{array}$ \\
\hline 1.27 & $\mathrm{SnPb}$ & SAC305 & 215 & 7589 & 7589 & 8577 & 9146 & 2184 & 2184 & 2186 & 3235 \\
\hline 1.27 & $\mathrm{SnPb}$ & SAC305 & 215 & 6367 & 6367 & 6486 & 6754 & 2682 & 2682 & 2699 & 2712 \\
\hline 1.27 & $\mathrm{SnPb}$ & SAC305 & 215 & n.f. & n.f. & n.f. & n.f. & 3170 & 3170 & 3271 & 3327 \\
\hline 1.27 & $\mathrm{SnPb}$ & SAC305 & 215 & n.f. & n.f. & n.f. & n.f. & 2170 & 2170 & 2312 & 2682 \\
\hline 1.27 & $\mathrm{SnPb}$ & SAC305 & 215 & n.f. & n.f. & n.f. & n.f. & 2263 & 2263 & 2273 & 2478 \\
\hline 1.27 & $\mathrm{SnPb}$ & SAC305 & 215 & 10054 & 10059 & n.f. & n.f. & n.f. & n.f. & n.f. & n.f. \\
\hline 1.27 & $\mathrm{SnPb}$ & SAC305 & 215 & 7233 & 7235 & 7278 & n.f. & 3115 & 3110 & 3152 & 3485 \\
\hline 1.27 & $\mathrm{SnPb}$ & SAC305 & 215 & n.f. & n.f. & n.f. & n.f. & 3430 & 3430 & 3445 & 3445 \\
\hline 1.27 & $\mathrm{SnPb}$ & SAC305 & 215 & 5782 & 5784 & 5801 & 6133 & 2613 & 2613 & 2618 & 2841 \\
\hline 1.27 & $\mathrm{SnPb}$ & SAC305 & 215 & 9040 & 9042 & 9062 & 9778 & 3275 & 3275 & 3312 & 3519 \\
\hline 1.27 & $\mathrm{SnPb}$ & SAC305 & 215 & n.f. & n.f. & n.f. & n.f. & n.f. & n.f. & n.f. & n.f. \\
\hline 1.27 & $\mathrm{SnPb}$ & SAC305 & 215 & 6737 & 6737 & 7267 & 9320 & 3010 & 3010 & 3010 & 3015 \\
\hline 1.27 & $\mathrm{SnPb}$ & SAC305 & 215 & n.f. & n.f. & n.f. & n.f. & 2699 & 2698 & 2810 & 2875 \\
\hline 1.27 & $\mathrm{SnPb}$ & SAC305 & 215 & n.f. & n.f. & n.f. & n.f. & n.f. & n.f. & n.f. & n.f. \\
\hline 1.27 & $\mathrm{SnPb}$ & SAC305 & 215 & 7353 & 7358 & 8515 & n.f. & 2945 & 2950 & 3050 & 3469 \\
\hline 1.27 & $\mathrm{SnPb}$ & SAC305 & 215 & 7801 & 7802 & 7896 & 9170 & n.f. & n.f. & n.f. & n.f. \\
\hline 1.27 & $\mathrm{SnPb}$ & SAC105 & 215 & 7088 & 7088 & 7325 & 9409 & 3538 & 3542 & 3548 & 3548 \\
\hline 1.27 & $\mathrm{SnPb}$ & SAC105 & 215 & 6385 & 6385 & 6385 & 7392 & 2456 & 2456 & 2459 & 2807 \\
\hline 1.27 & $\mathrm{SnPb}$ & SAC105 & 215 & 9620 & 9620 & 9620 & n.f. & 1459 & 1459 & 1528 & 1940 \\
\hline 1.27 & $\mathrm{SnPb}$ & SAC105 & 215 & 5939 & 5939 & 5942 & n.f. & 2318 & 2318 & 2321 & 2723 \\
\hline 1.27 & $\mathrm{SnPb}$ & SAC105 & 215 & 5996 & 5999 & 6004 & n.f. & 2115 & 2115 & 2117 & 2131 \\
\hline 1.27 & $\mathrm{SnPb}$ & SAC105 & 215 & 5441 & 5441 & 5491 & 5646 & 1404 & 1404 & 1407 & 1444 \\
\hline 1.27 & $\mathrm{SnPb}$ & SAC105 & 215 & 5538 & 5610 & 5807 & n.f. & 2426 & 2426 & 2426 & 2433 \\
\hline 1.27 & $\mathrm{SnPb}$ & SAC105 & 215 & 3796 & 3797 & 3822 & 4091 & 1810 & 1810 & 1837 & 1843 \\
\hline 1.27 & $\mathrm{SnPb}$ & SAC105 & 215 & 8552 & 8556 & 8587 & n.f. & 2502 & 2502 & 2634 & 3336 \\
\hline 1.27 & $\mathrm{SnPb}$ & SAC105 & 215 & 6649 & 6649 & 6649 & 8955 & 2096 & 2097 & 2097 & 3530 \\
\hline 1.27 & $\mathrm{SnPb}$ & SAC105 & 215 & 4853 & 4853 & 4859 & 5951 & 1834 & 1834 & 1836 & 1836 \\
\hline 1.27 & $\mathrm{SnPb}$ & SAC105 & 215 & 6651 & 6652 & 6662 & 8231 & n.f. & n.f. & n.f. & n.f. \\
\hline 1.27 & $\mathrm{SnPb}$ & SAC105 & 215 & 7233 & 7233 & 7242 & n.f. & 2644 & 2644 & 2651 & 3311 \\
\hline 1.27 & $\mathrm{SnPb}$ & SAC105 & 215 & 3265 & 3366 & 3508 & 4433 & 2577 & 2577 & 2579 & 2672 \\
\hline 1.27 & $\mathrm{SnPb}$ & SAC105 & 215 & 7002 & 7002 & 7002 & n.f. & 2352 & 2352 & 2357 & 2366 \\
\hline 1.27 & $\mathrm{SnPb}$ & SAC105 & 215 & 5881 & 5881 & 5882 & 9288 & 2360 & 2360 & 2366 & 2366 \\
\hline 1.27 & $\mathrm{SnPb}$ & SAC105 & 215 & 8488 & 8488 & 8488 & 9456 & 2108 & 2108 & 2156 & 2739 \\
\hline 1.27 & $\mathrm{SnPb}$ & SAC105 & 215 & 9007 & 9007 & 9007 & 9338 & 3131 & 3131 & 3132 & 3501 \\
\hline 1.27 & $\mathrm{SnPb}$ & SAC105 & 215 & 4863 & 4863 & 4867 & 4998 & 2953 & 2953 & 2956 & 2969 \\
\hline 1.27 & $\mathrm{SnPb}$ & SAC105 & 215 & 7966 & 7966 & 7966 & n.f. & 2703 & 2703 & 2710 & 3082 \\
\hline
\end{tabular}




\begin{tabular}{|c|c|c|c|c|c|c|c|c|c|c|c|}
\hline \multicolumn{4}{|c|}{ Treatment } & \multicolumn{4}{|c|}{$0^{\circ} \mathrm{C}$ to $100{ }^{\circ} \mathrm{C}$ TCR } & \multicolumn{4}{|c|}{$-40{ }^{\circ} \mathrm{C}$ to $125^{\circ} \mathrm{C}$ TCR } \\
\hline $\begin{array}{l}\text { Pkg } \\
\text { Desc } \\
(\mathrm{mm})\end{array}$ & $\begin{array}{l}\text { Paste } \\
\text { Alloy }\end{array}$ & $\begin{array}{c}\text { Ball } \\
\text { Alloy }\end{array}$ & $\begin{array}{l}\text { PRT } \\
\left({ }^{\circ} \mathbf{C}\right)\end{array}$ & $\underset{\text { and } R}{\overline{\mathbf{X}}}$ & $\begin{array}{l}\text { IPC- } \\
\text { 9701A }\end{array}$ & $500 \Omega$ & $\begin{array}{l}\text { Inf. } \\
\text { Resist. }\end{array}$ & $\underset{\text { and } R}{\overline{\mathbf{X}}}$ & $\begin{array}{c}\text { IPC- } \\
\text { 9701A }\end{array}$ & $500 \Omega$ & $\begin{array}{c}\text { Inf. } \\
\text { Resist. }\end{array}$ \\
\hline 1.27 & $\mathrm{SnPb}$ & SACX & 215 & n.f. & n.f. & n.f. & n.f. & 1663 & 1663 & 1663 & 1665 \\
\hline 1.27 & $\mathrm{SnPb}$ & SACX & 215 & 4494 & 4494 & 4476 & 4897 & 2274 & 2273 & 2281 & 2316 \\
\hline 1.27 & $\mathrm{SnPb}$ & SACX & 215 & 2470 & 2470 & 2545 & 2561 & 1444 & 1444 & 1513 & 1522 \\
\hline 1.27 & $\mathrm{SnPb}$ & SACX & 215 & 8991 & 8991 & 9010 & n.f. & 2366 & 2366 & 2367 & 3520 \\
\hline 1.27 & $\mathrm{SnPb}$ & SACX & 215 & 6240 & 6240 & 6240 & 9057 & 2541 & 2541 & 2552 & 2967 \\
\hline 1.27 & $\mathrm{SnPb}$ & SACX & 215 & 6136 & 6147 & 6223 & 7533 & 2763 & 2763 & 2763 & 2794 \\
\hline 1.27 & $\mathrm{SnPb}$ & SACX & 215 & 6346 & 6346 & 6371 & 6999 & 2468 & 2469 & 2507 & 2558 \\
\hline 1.27 & $\mathrm{SnPb}$ & SACX & 215 & 5730 & 5731 & 5731 & 6019 & 2062 & 2063 & 2203 & 2326 \\
\hline 1.27 & $\mathrm{SnPb}$ & SACX & 215 & 4863 & 4866 & 4895 & 7604 & 2118 & 2120 & 2121 & 2266 \\
\hline 1.27 & $\mathrm{SnPb}$ & SACX & 215 & 3707 & 3707 & 3714 & 3866 & 2355 & 2350 & 2474 & 3124 \\
\hline 1.27 & $\mathrm{SnPb}$ & SACX & 215 & 8510 & 8512 & 8521 & 10083 & 2600 & 2601 & 2601 & 2604 \\
\hline 1.27 & $\mathrm{SnPb}$ & SACX & 215 & 9319 & 9495 & 10021 & n.f. & 2118 & 2143 & 2190 & 2449 \\
\hline 1.27 & $\mathrm{SnPb}$ & SACX & 215 & n.f. & n.f. & n.f. & n.f. & 1939 & 1940 & 1948 & 2058 \\
\hline 1.27 & $\mathrm{SnPb}$ & SACX & 215 & 3938 & 3938 & 5401 & 7201 & 2286 & 2287 & 2325 & 2325 \\
\hline 1.27 & $\mathrm{SnPb}$ & SACX & 215 & n.f. & n.f. & n.f. & n.f. & 3484 & 3484 & 3492 & 3497 \\
\hline 1.27 & $\mathrm{SnPb}$ & SACX & 215 & 3327 & 3326 & 3414 & 3414 & 1861 & 1864 & 1894 & 1894 \\
\hline 1.27 & $\mathrm{SnPb}$ & SACX & 215 & 2128 & 2128 & 2571 & 2668 & 2208 & 2208 & 2262 & 2754 \\
\hline 1.27 & $\mathrm{SnPb}$ & SACX & 215 & n.f. & n.f. & n.f. & n.f. & 3215 & 3215 & 3216 & 3523 \\
\hline 1.27 & $\mathrm{SnPb}$ & SACX & 215 & 5302 & 5302 & 5302 & 6365 & 2492 & 2492 & 2493 & 2722 \\
\hline 1.27 & $\mathrm{SnPb}$ & SACX & 215 & 4270 & 4270 & 4422 & 5292 & 2499 & 2499 & 2499 & 2601 \\
\hline 1.27 & $\mathrm{SnPb}$ & LF35 & 215 & 2620 & 2620 & 2880 & 2885 & 1125 & 1137 & 1246 & 1407 \\
\hline 1.27 & $\mathrm{SnPb}$ & LF35 & 215 & 3934 & 3936 & 4384 & 4410 & 1121 & 1130 & 1790 & 1793 \\
\hline 1.27 & $\mathrm{SnPb}$ & SAC105 & 220 & 6732 & 6732 & 6741 & 7924 & 2448 & 2448 & 2452 & 2799 \\
\hline 1.27 & $\mathrm{SnPb}$ & SAC105 & 220 & 5483 & 5483 & 5490 & 7419 & 1585 & 1585 & 1614 & 1616 \\
\hline 1.27 & $\mathrm{SnPb}$ & SAC105 & 220 & 8195 & 8195 & 8230 & n.f. & 1727 & 1727 & 1759 & 1895 \\
\hline 1.27 & $\mathrm{SnPb}$ & SAC105 & 220 & n.f. & n.f. & n.f. & n.f. & 2490 & 2489 & 2490 & 3020 \\
\hline 1.27 & $\mathrm{SnPb}$ & SAC105 & 220 & 4733 & 4734 & 4757 & 5835 & 1914 & 1914 & 1920 & 1942 \\
\hline 1.27 & $\mathrm{SnPb}$ & SAC105 & 220 & 8939 & 8939 & 8947 & 9232 & 2356 & 2356 & 2369 & 2369 \\
\hline 1.27 & $\mathrm{SnPb}$ & SAC105 & 220 & 5467 & 5471 & 5515 & n.f. & 1567 & 1567 & 1585 & 1587 \\
\hline 1.27 & $\mathrm{SnPb}$ & SAC105 & 220 & 6087 & 6087 & 6087 & 6258 & 2545 & 2543 & 2554 & 2637 \\
\hline 1.27 & $\mathrm{SnPb}$ & SAC105 & 220 & 4378 & 4378 & 4783 & 6796 & 1766 & 1766 & 1784 & 2060 \\
\hline 1.27 & $\mathrm{SnPb}$ & SAC105 & 220 & 7232 & 7236 & 7262 & 8368 & 1778 & 1775 & 1786 & 1818 \\
\hline 1.27 & $\mathrm{SnPb}$ & SAC105 & 220 & 5536 & 5536 & 5578 & 6322 & 1356 & 1356 & 1399 & 1441 \\
\hline 1.27 & $\mathrm{SnPb}$ & SAC105 & 220 & n.f. & n.f. & n.f. & n.f. & 1390 & 1390 & 1402 & 1537 \\
\hline 1.27 & $\mathrm{SnPb}$ & SAC105 & 220 & 9437 & 9437 & 9442 & 9443 & 1333 & 1333 & 1346 & 1346 \\
\hline 1.27 & $\mathrm{SnPb}$ & SAC105 & 220 & 6930 & 6930 & 6962 & 7667 & 1448 & 1448 & 1464 & 1500 \\
\hline
\end{tabular}




\begin{tabular}{|c|c|c|c|c|c|c|c|c|c|c|c|}
\hline \multicolumn{4}{|c|}{ Treatment } & \multicolumn{4}{|c|}{$0^{\circ} \mathrm{C}$ to $100^{\circ} \mathrm{C}$ TCR } & \multicolumn{4}{|c|}{$-40{ }^{\circ} \mathrm{C}$ to $125^{\circ} \mathrm{C}$ TCR } \\
\hline $\begin{array}{c}\text { Pkg } \\
\text { Desc } \\
(\mathrm{mm})\end{array}$ & $\begin{array}{l}\text { Paste } \\
\text { Alloy }\end{array}$ & $\begin{array}{c}\text { Ball } \\
\text { Alloy }\end{array}$ & $\begin{array}{l}\text { PRT } \\
\left({ }^{\circ} \mathbf{C}\right)\end{array}$ & $\begin{array}{c}\bar{X} \\
\text { and } R\end{array}$ & $\begin{array}{c}\text { IPC- } \\
\text { 9701A }\end{array}$ & $500 \Omega$ & $\begin{array}{c}\text { Inf. } \\
\text { Resist. }\end{array}$ & $\underset{\text { and } R}{\overline{\mathbf{X}}}$ & $\begin{array}{l}\text { IPC- } \\
\text { 9701A }\end{array}$ & $500 \Omega$ & $\begin{array}{l}\text { Inf. } \\
\text { Resist. }\end{array}$ \\
\hline 1.27 & $\mathrm{SnPb}$ & SAC105 & 220 & 4180 & 4180 & 4218 & 4331 & 2903 & 2903 & 2911 & 3068 \\
\hline 1.27 & $\mathrm{SnPb}$ & SAC105 & 220 & 5018 & 5018 & 5023 & 5448 & 2719 & 2719 & 2719 & 2797 \\
\hline 1.27 & $\mathrm{SnPb}$ & SAC105 & 220 & 7894 & 7894 & 7895 & 8023 & 1817 & 1819 & 2028 & 2031 \\
\hline 1.27 & $\mathrm{SnPb}$ & SAC105 & 220 & 7670 & 7676 & 7676 & n.f. & 1983 & 1983 & 1986 & 1986 \\
\hline
\end{tabular}




\section{Appendix B \\ AIC Values for Weibull and Lognormal Distributions}

\begin{tabular}{|c|c|c|c|c|}
\hline Weibull AIC & Lognormal AIC & Paste Alloy & Ball Alloy & Pitch (mm) \\
\hline 246.67 & 244.49 & $\mathrm{SbPb}$ & $\mathrm{SbPb}$ & 0.80 \\
\hline 262.44 & 262.30 & $\mathrm{SbPb}$ & $\mathrm{SbPb}$ & 0.50 \\
\hline 298.39 & 295.75 & $\mathrm{SbPb}$ & $\mathrm{SbPb}$ & 1.00 \\
\hline 340.24 & 335.71 & $\mathrm{SbPb}$ & $\mathrm{SbPb}$ & 1.27 \\
\hline 193.73 & 192.87 & $\mathrm{SbPb}$ & SAC305 & 1.27 \\
\hline 282.22 & 279.71 & $\mathrm{SbPb}$ & SAC305 & 0.50 \\
\hline 307.11 & 310.75 & $\mathrm{SbPb}$ & SAC305 & 0.80 \\
\hline 349.73 & 353.78 & $\mathrm{SbPb}$ & SAC305 & 1.00 \\
\hline 290.86 & 291.10 & $\mathrm{SbPb}$ & SAC105 & 0.80 \\
\hline 294.49 & 291.94 & $\mathrm{SbPb}$ & SAC105 & 0.50 \\
\hline 325.43 & 325.06 & $\mathrm{SbPb}$ & SAC105 & 1.00 \\
\hline 328.92 & 329.93 & $\mathrm{SbPb}$ & SAC105 & 1.27 \\
\hline 299.42 & 302.36 & $\mathrm{SbPb}$ & SACX & 1.00 \\
\hline 306.72 & 304.60 & $\mathrm{SbPb}$ & SACX & 1.27 \\
\hline 310.94 & 309.49 & $\mathrm{SbPb}$ & SACX & 0.50 \\
\hline 313.52 & 312.34 & $\mathrm{SbPb}$ & SACX & 0.80 \\
\hline 236.75 & 239.28 & $\mathrm{SnPb}$ & LF35 & 0.50 \\
\hline 288.14 & 285.45 & $\mathrm{SnPb}$ & SAC105 & 1.27 \\
\hline 293.79 & 294.90 & $\mathrm{SnPb}$ & SAC105 & 1.00 \\
\hline 207.54 & 206.79 & LF & SAC305 & 1.27 \\
\hline 306.03 & 307.56 & $\mathrm{LF}$ & SAC305 & 0.50 \\
\hline 314.03 & 314.04 & $\mathrm{LF}$ & SAC305 & 0.80 \\
\hline 326.91 & 329.65 & $\mathrm{LF}$ & SAC305 & 1.00 \\
\hline 245.15 & 240.99 & $\mathrm{LF}$ & SAC105 & 1.27 \\
\hline 292.77 & 291.41 & $\mathrm{LF}$ & SAC105 & 0.80 \\
\hline 298.17 & 299.07 & LF & SAC105 & 0.50 \\
\hline 311.08 & 310.50 & $\mathrm{LF}$ & SAC105 & 1.00 \\
\hline 284.37 & 280.33 & LF & SACX & 0.80 \\
\hline 302.07 & 300.66 & LF & SACX & 0.50 \\
\hline 309.45 & 306.71 & LF & SACX & 1.00 \\
\hline 321.49 & 318.98 & $\mathrm{LF}$ & SACX & 1.27 \\
\hline 295.64 & 291.06 & LF & SAC205 & 1.27 \\
\hline 300.05 & 298.15 & LF & SAC205 & 1.00 \\
\hline 300.61 & 298.65 & LF & SAC205 & 0.80 \\
\hline 301.93 & 301.60 & LF & SAC205 & 0.50 \\
\hline
\end{tabular}




\begin{tabular}{|c|c|c|c|c|}
\hline Weibull AIC & Lognormal AIC & Paste Alloy & Ball Alloy & Pitch (mm) \\
\hline 293.12 & 293.20 & LF & LF35 & 0.50 \\
\hline 294.07 & 297.05 & $\mathrm{SbPb}$ & $\mathrm{SbPb}$ & 0.50 \\
\hline 305.16 & 300.19 & $\mathrm{SbPb}$ & $\mathrm{SbPb}$ & 1.00 \\
\hline 306.35 & 306.53 & $\mathrm{SbPb}$ & $\mathrm{SbPb}$ & 1.27 \\
\hline 317.67 & 315.35 & $\mathrm{SbPb}$ & $\mathrm{SbPb}$ & 0.80 \\
\hline 303.81 & 302.24 & $\mathrm{SbPb}$ & SAC305 & 0.50 \\
\hline 306.94 & 306.51 & $\mathrm{SbPb}$ & SAC306 & 0.80 \\
\hline 311.83 & 307.12 & $\mathrm{SbPb}$ & SAC307 & 1.00 \\
\hline 325.32 & 324.44 & $\mathrm{SbPb}$ & SAC308 & 1.27 \\
\hline 310.14 & 310.73 & $\mathrm{SbPb}$ & SAC107 & 1.00 \\
\hline 311.82 & 310.77 & $\mathrm{SbPb}$ & SAC108 & 1.27 \\
\hline 312.49 & 315.46 & $\mathrm{SbPb}$ & SAC105 & 0.50 \\
\hline 315.39 & 318.24 & $\mathrm{SbPb}$ & SAC106 & 0.80 \\
\hline 301.43 & 302.67 & $\mathrm{SbPb}$ & SACX & 1.27 \\
\hline 308.11 & 308.37 & $\mathrm{SbPb}$ & SACX & 0.80 \\
\hline 309.89 & 315.38 & $\mathrm{SbPb}$ & SACX & 0.50 \\
\hline 310.51 & 315.43 & $\mathrm{SbPb}$ & SACX & 1.00 \\
\hline 218.22 & 216.23 & $\mathrm{SnPb}$ & LF35 & 0.50 \\
\hline 279.01 & 278.01 & $\mathrm{SnPb}$ & SAC105 & 1.00 \\
\hline 293.57 & 292.36 & $\mathrm{SnPb}$ & SAC105 & 1.27 \\
\hline 294.34 & 294.09 & LF & SAC305 & 0.80 \\
\hline 296.23 & 299.58 & $\mathrm{LF}$ & SAC305 & 0.50 \\
\hline 297.70 & 301.07 & LF & SAC305 & 1.00 \\
\hline 314.49 & 315.69 & LF & SAC305 & 1.27 \\
\hline 299.91 & 300.45 & $\mathrm{LF}$ & SAC105 & 1.27 \\
\hline 309.25 & 309.74 & LF & SAC105 & 0.80 \\
\hline 310.47 & 312.50 & $\mathrm{LF}$ & SAC105 & 0.50 \\
\hline 314.75 & 313.15 & $\mathrm{LF}$ & SAC105 & 1.00 \\
\hline 280.88 & 278.20 & LF & SACX & 0.50 \\
\hline 286.30 & 286.87 & LF & SACx & 0.80 \\
\hline 311.41 & 317.63 & $\mathrm{LF}$ & SACX & 1.00 \\
\hline 325.47 & 327.82 & LF & SACX & 1.27 \\
\hline 302.51 & 301.92 & LF & SAC205 & 1.27 \\
\hline 305.62 & 305.88 & LF & SAC205 & 1.00 \\
\hline 313.80 & 313.23 & LF & SAC205 & 0.80 \\
\hline 315.93 & 317.72 & LF & SAC205 & 0.50 \\
\hline 315.87 & 320.52 & $\mathrm{LF}$ & LF35 & 0.50 \\
\hline
\end{tabular}

